\title{
Krzysztof Frankowicz*
}

\section{Renesansowy księgozbiór krakowskiego lekarza Stanisława Różanki}

Życie i działalność krakowskiego doktora medycyny Stanisława Różanki były dobrze przebadane w polskiej historiografii. Dwaj uczeni, Jan Lachs ${ }^{1}$ i Henryk Barycz ${ }^{2}$, poświęcili mu wiele miejsca w swoich naukowych publikacjach. Nie powinno to dziwić, gdyż Różanka był osobą wyróżniającą się w renesansowym Krakowie. Świetnie wykształcony doktor filozofii i medycyny Uniwersytetu Padewskiego, sekretarz i lekarz hetmana Jana Tarnowskiego, członek kalwińskiego zboru, rajca miejski i burmistrz, humanista i bibliofil, a przy tym człowiek majętny i zaradny życiowo, był przykładem nieprzeciętnego mieszczanina z Krakowa. W okresie jego działalności medycy, prawnicy, notariusze, drukarze i uczeni uniwersyteccy wnosili widoczne ożywienie w życie intelektualne stolicy królestwa, odgrywali istotną rolę w mieście dworu i skupionych wokół niego urzędów, administracji kościelnej i świeckiej, gdzie działał jedyny w państwie uniwersytet.

* historyk, bibliotekarz, doktorant na Wydziale Filozoficznym Akademii Ignatianum; zainteresowania badawcze: kultura renesansu, historia bibliotek, cywilizacja i kultura XIX w.; e-mail: krzysztof.k.frankowicz@uj.edu.pl

${ }^{1}$ Jan Lachs, Ephorinus i Rożanka: z dziejów uczestnictwa lekarzy w ruchu reformacyjnym, „Reformacja w Polsce” 1922, R. 2, s. 185-197; idem, Krakowskie ksiegozbiory lekarskie z XVI-go wieku, „Archiwum dla Historyi Literatury w Polsce” 1913, t. 13, s. 328-412; idem, Kronika lekarzy krakowskich do końca XVI wieku: przyczynki archiwalne, „Archiwum do Dziejów Literatury i Oświaty w Polsce” 1910, t. 12, s. 89-176; id em, Polscy uczniowie Padewskiej Szkoty Lekarskiej, „Archiwum Historii i Filozofii Medycyny oraz Historii Nauk Przyrodniczych” 1925.

${ }^{2}$ Henryk Barycz, Rożanka (Rosarius) Stanisław, [w:] PSB, t. 32, Wrocław 19891991, s. 431-433; idem, Saga kleparskiej rodziny Różanków. Historia trochę kryminalna, [w]: id em, Z epoki renesansu, reformacji i baroku: prądy-idee-ludzie - ksiażki, Warszawa 1971, s. 400-452; idem, Rozwój nauki polskiej w dobie odrodzenia, [w:] Odrodzenie w Polsce. Historia nauki, cz. 1, red. Bogdan Suchodolski, Warszawa 1956, s. 67, 69; idem, Z zaścianka na Parnas. Drogi kulturowego rozwoju Jana Kochanowskiego i jego rodu, Kraków 1981. 
Zawartość księgozbioru S. Różanki jest znana od ponad stu lat dzięki publikacji J. Lachsa Krakowskie księgozbiory lekarskie z XVI w. Badacz ten wydał inwentarze Różanki z dwóch dokumentów ${ }^{3}$ z zasobu Archiwum Narodowego w Krakowie ${ }^{4}$. Jednak opublikowany przez niego w 1913 r. materiał nie jest wolny od błędów i przeinaczeń. Jest także niepełny, gdyż autor sporządził ...spis wszystkich dziet lekarskich, [...] nie pomijajac przytem przyrodniczych, matematycznych i filozoficznych, ze względu na ważny wplyw tych nauk na wykształcenie i myślenie lekarskie ${ }^{5}$. Zamysł, aby pokazać całą bibliotekę, wydawał się więc bardzo interesujący. Jakie jeszcze księgi były w posiadaniu Różanki? Jak szerokie były jego zainteresowania? Porównując opublikowane wersje inwentarzy z oryginałami, okazało się, iż każdy ze spisów, z rkps 184 i z rkps 202, jest bogatszy o 200 dzieł. W obydwu inwentarzach księgozbiór Różanki liczył blisko 400 pozycji, co stawia go w gronie właścicieli największych bibliotek w renesansowym Krakowie.

Stanisław Różanka, zwany Rosariusem, urodził się ok. 1520 r. w podkrakowskim wówczas Kleparzu, w licznej mieszczańskiej rodzinie karczmarza Marcina Różanki ${ }^{6}$. Jeden z młodszych braci Stanisława, Walenty, został prawnikiem i sekretarzem królewskim ${ }^{7}$, drugi brat Jan był kuśnierzem ${ }^{8}$. W tym samym czasie w rodzinie Różanków ok. 1522 r. urodził się drugi Stanisław, prawdopodobnie stryjeczny brat pierwszego, późniejszy doktor medycyny, kanonik wrocławski i głogowski, nazywany Rosatusem9 ${ }^{9}$. Nasz Stanisław

${ }^{3}$ Niesłuszny zatem jest zarzut stawiany przez H. Barycza, jakoby J. Lachs nie znał drugiego inwentarza S. Różanki, H. Barycz, Saga..., s. 410-411, przyp. 17.

${ }^{4}$ ANK, Akta miasta Krakowa, rkps 184 (Adv. Crac.), s. 871-889 (dalej: rkps 184), rkps 202 (Adv. Crac.), s. 794-811 (dalej: rkps 202).

5 J. Lachs, Krakowskie..., s. 330.

${ }^{6}$ H. Barycz, Różanka (Rosarius)..., s. 431; idem, Saga..., s. 406. Wg J. Lachsa ojcem Stanisława był Drwienski (,,alias Roszanski”), J. Lachs, Kronika..., s. 128. Podobnie uważa W. Urban, pisząc, że Stanisław był synem „Marcina Drwieńskiego, doktora artium i medycyny", Wacław Urban, Heretycy parafi Mariackiej w Krakowie w 1568 r., „Odrodzenie i Reformacja w Polsce” 1987, t. 32, s. 172. Z kolei L. Hajdukiewicz użył formy „Marcin Drwięski-Różanka”, Historia nauki polskiej, t. 6, red. Bogdan Suchodolski, Dokumentacja bio-bibliograficzna. Indeks biograficzny t. 1 i 2, oprac. Leszek Hajdukiewicz, Wrocław, 1974, s. 575.

${ }^{7}$ H. Barycz, Saga..., s. 432-433; idem, Różanka Walenty, [w:] PSB, t. 32, Wrocław 1989-1991, s. 434.

${ }^{8}$ Idem, Saga..., s. 406.

9 Idem, Różanka (Rosatus) Stanisław, [w:] PSB, t. 32, Wrocław 1989-1991, s. 433434. H. Barycz przedstawił dwie koncepcje przyczyny używania zlatynizowanej wersji nazwiska „Różanka”. Otóż w przypadku Stanisława Rosariusa mogło dojść do tego pod wpływem antyku i fascynacji kulturą starożytną w czasach padewskich lub jeszcze wcze- 
pierwsze nauki pobierał we floriańskiej lub mariackiej szkole parafialnej. W 1538 r. wpisał się na Uniwersytet Krakowski, lecz dość szybko zamiast poświecić się regularnemu studiowaniu, rozwój naukowy oparł o krakowskie koło humanistów ${ }^{10}$. Obracał się wówczas w gronie profesorów Szymona Marycjusza z Pilzna ${ }^{11}$ i Mikołaja Śmieszkowica (Gelasinusa) ${ }^{12}$, humanisty i królewskiego sekretarza Andrzeja Patrycego Nideckiego ${ }^{13}$ oraz pisarza i dyplomaty Marcina Kromera ${ }^{14}$. W 1545 r. Różanka został pisarzem na dworze hetmana i kasztelana krakowskiego Jana Tarnowskiego ${ }^{15}$. Dzięki temu stanowisku uzyskał możliwość nawiązania nowych, ważnych kontaktów. Zbliżył się m.in. do biskupa krakowskiego Andrzeja Zebrzydowskiego, który okazał mu dużą życzliwość, umożliwiając wyjazd do Italii w towarzystwie A. P. Nideckiego ${ }^{16}$. W 1553 r. Różanka przybył do Padwy z zamiarem zdobycia wiedzy z zakresu medycyny. Aby rozpocząć zaplanowane studia, musiał najpierw uzupełnić swoją wiedzę z filozofii, w czym istotną rolę odegrał padewski profesor filozofii, zwolennik Arystotelesa, Marcantonio Passeri z Genui ${ }^{17}$. Nauki w Padwie uwieńczył dwoma doktoratami: z filozofii i medycyny uzyskanymi jednego dnia, 12 maja 1556 r. ${ }^{18}$ Świadkami promocji byli dwaj Polacy, krakowski kanonik, siostrzeniec krakowskiego

śniej, w latach 40., kiedy to obydwaj Stanisławowie zawarli umowę i od tej pory jeden został Rosariusem, a drugi Rosatusem, H. Barycz, Różanka (Rosarius)..., s. 431; idem, Saga..., s. 419.

${ }^{10}$ Id em, Różanka (Rosarius)..., s. 431; idem, Saga..., s. 406.

11 Stanisław Kot, Korespondencja Szymona Mariciusza z Pilzna z lat 1551-1555, „Archiwum do Dziejów Literatury i Oświaty” 1929, t. 16, s. 7-8, 86; Henryk Barycz, Maricjusz (Marycjusz) Szymon, [w:] PSB, t. 20, Wrocław 1975, s. 12.

${ }_{12}$ Agnieszka Biedrzycka, Zdzisław Pietrzyk, Śmieszkowic (Gelasinus) Mikołaj, [w:] PSB, t. 51, Warszawa 2016-2017, s. 83.

${ }^{13}$ Leszek Hajdukiewicz, Nidecki Patrycy Andrzej, [w:] PSB, t. 22, Wrocław 1977, s. 713.

${ }^{14}$ H. Barycz, Kromer Marcin, [w:] PSB, t. 15, Wrocław 1970, s. 319.

15 Włodzimierz Dworzaczek, Hetman Jan Tarnowski: z dziejów możnowładztwa małopolskiego, Warszawa 1985, s. 278; H. Barycz, Różanka (Rosarius)..., s. 431.

16 Jan Ptaśnik, Bonerowie, „Rocznik Krakowski” 1905, R. 7, s. 119; J. Lachs, Ephorinus i Różanka..., s. 191; H. Barycz, Saga..., s. 409.

${ }^{17}$ H. Barycz, Różanka (Rosarius)..., s. 431; Danuta Quirini-Popławska, Środowisko naukowe Uniwerystetu Padewskiego w okresie studiów Klemensa Janickiego, „Symbolae Philologorum Posnaniensium Graecae et Latinae" 2017, t. 27, z. 2, s. 58.

18 Stanisław Windakiewicz, Materyaly do historyi Polaków w Padwie, „Archiwum do Dziejów Literatury i Oświaty w Polsce" 1901, t. 7, s. 15, 33; Stanisław Łempicki, Renesans i Humanizm w Polsce. Materiaty do studiów, Warszawa 1952, s. 60; Historia nauki polskiej, t. 6, s. 576; H. Barycz, Różanka (Rosarius)..., s. 431; idem, Saga ..., s. 417. 
biskupa Samuela Maciejowskiego Marian Leżeński ${ }^{19}$ i poseł polski w Rzymie Stanisław Maciejowski ${ }^{20}$.

Pobyt w Italii w kolebce humanizmu, możliwość obcowania z antykiem spowodowały zauroczenie starożytnością, tak grecką, jak i rzymską. Różanka uległ urokowi współczesnej renesansowej kultury, opanował też język włoski. Antyczna przeszłość i humaniora ukształtowały na stałe jego umysł. Wiedzę medyczną przekazywali mu wybitni profesorowie: Giovanni Battista de Monte (Montanus), medyk, humanista, filolog i filozof ${ }^{21}$; Bassiano Lando, lekarz i humanista ${ }^{22}$; Vincenzo Casalis z Brescii ${ }^{23}$ i Walenty z Lublina (Walenty Sierpiński), doktor medycyny i wydawca prac medycznych ${ }^{24}$. Można założyć, że dzięki Różance Casalis dedykował Janowi Tarnowskiemu niewielką rozprawę medyczną, we wstępie nazywając Rosariusa „mężem osobliwej erudycji" ${ }^{25}$. Szczególną więź nawiązał ze słynnym padewskim botanikiem Melchiorre Guilandinim ${ }^{26}$. Jeszcze po powrocie do Krakowa utrzymywał z nim korespondencję, w której nazywany był „najuczeńszym lekarzem"27. Podczas kilkuletniego pobytu w Italii Stanisław Różanka nawiązał wiele znajomości. W Padwie obracał się w kręgu Paolo Manuzia wraz z Andrzejem Patrycym Nideckim, doktorem medycyny i teologii, kró-

19 Jan Ślaski, Marian Leżeński - padewczyk zapomniany, „Odrodzenie i Reformacja w Polsce" 2004, t. 47, s. 67, 75, 91.

${ }^{20} \mathrm{Wg}$ J. Ślaskiego obecność Stanisława Maciejowskiego, właściciela miasta Chodel w woj. lubelskim, była fikcyjna, J. Ślaski, Marian Leżeński..., s. 73-74.

${ }^{21}$ D. Quirini-Popławska, Środowisko naukowe..., s. 57.

${ }^{22}$ H. Barycz, Spojrzenia w przeszłość polsko-włoska, Wrocław 1965, s. 221.

${ }^{23}$ Idem, Różanka (Rosarius)..., s. 431.

${ }^{24}$ J. Lachs, Polscy uczniowie..., s. 22; idem, Ephorinus i Różanka..., s.191; Wanda Baczkowska, Sierpiński (Sierpowski, z Lublina, Lubelczyk) Walenty, [w:] PSB, t. 37 , Warszawa 1996-1997, s. 359.

${ }^{25}$ Giovanni Bapttista de Monte, ... Explicatio eorum, quae pertinent, tum ad qualitates simplicium medicamentorum, tum ad eorundem compositionem. ([ed.:] Vincentius Casalis), Venetiis Apud Balthassarem Constantinum, 1555.

26 J. Ślaski, Marian Leżeński..., s. 88; H. Barycz, Z zaścianka..., s. 155; idem, Saga..., s. 415-416; D. Quirini-Popławska, Z Prus do Italii. Profesor Uniwersytetu Padewskiego Melchiorre Guilandini i jego podróże, „Portolana. Studia Mediterranea” 2009, vol. 4, s. 151.

${ }^{27}$ Guilandinus Melchior Borussus, De Stirpibus aliquot, Epistolae V. Melchioris Guilandini Borussi. R. IIII. Conradi Gesneri Tigurini 1. Eiusdem Guilandini Ad Illustrem Comitem Nicolaum a Salmo etc. Manucodiattae, hoc est aniculae Dei descriptio. Adiecta est Andreae Patricii Ad Gabrielem Fallopium praefatio, Patavii Apud Gratiosum Perchacinum. 1558, na str. 5: Melchior Guilandius Borussus R. Stanislao Rosario Polono S. P. D.; J. Lachs, Ephorinus i Różanka..., s. 192, 194; Historia nauki polskiej, t. 6, s. 576; D. Quirini-Popławska, Z Prus..., s. 151; H. Barycz, Różanka (Rosarius)..., s. 431. 
lewskim sekretarzem Stanisławem Fogelwederem ${ }^{28}$, Marianem Leżeńskim, medykiem Sylwestrem Roguckim ${ }^{29}$, humanistą i dyplomatą Andrzejem Dudyczem $^{30}$, a także z Janem Kochanowskim ${ }^{31}$.

Powrót do Polski to także powrót na dwór J. Tarnowskiego, ale nie w charakterze urzędnika, lecz nadwornego medyka ${ }^{32}$. Polecił go mistrz z Padwy Walenty z Lublina, podnosząc zalety charakteru i wykształcenie Różanki ${ }^{33}$. Zaskarbił sobie zaufanie nie tylko hetmana, lecz także jego syna Jana Krzysztofa i córki Zofii ${ }^{34}$. Porad medycznych udzielał nie tylko w Krakowie, a z lekarskimi konsultacjami udawał się nawet na Węgry ${ }^{35}$. Ok. 1560 r. porzucił kościelne beneficja (kanonię sandomierską, plebanię w Sobótce, psałterię katedralną w Krakowie) i zawarł małżeństwo z Brygidą, córką rajcy krakowskiego i lekarza Wojciecha Krainy, co z pewnością przyczyniło się do ugruntowania jego pozycji w królewskim mieście ${ }^{36}$. Wraz z późniejszym rektorem Uniwersytetu Krakowskiego Marcinem Foxem był egzekutorem testamentu lekarza Jakuba Gajera ${ }^{37}$. W 1570 r. został rajcą, a następnie burmistrzem Krakowa ${ }^{38}$. Do magistratu krakowskiego Różan-

${ }^{28}$ Łukasz Kurdybacha, Fogelweder Stanisław, [w:] PSB, t. 7, Kraków 1948-1958, s. $45-46$.

${ }^{29}$ Andrzej Sołtan, Roguski (Rogucki) Sylwester, [w:] PSB, t. 31, Wrocław 19881989, s. 487.

${ }^{30}$ H. Barycz, Dudith (w polskim brzmieniu Dudicz) Sbardellat Andrzej, [w:] PSB, t. 5, Kraków 1939-1946, s. 445.

31 S. Łempicki, Renesans..., s. 59-60; Łukasz Kurdybacha, Stanisław Fogelweder - humanista i dyplomata polski XVI w., [w:] idem, Pisma wybrane, t. 3, Warszawa 1976, s. 14, 16; Janowi Kochanowskiemu - ziemia rodzinna: księga referatów radomsko-kielecko-czarnoleskiej sesji naukowej 450-lecia urodzin poety w dniach 29-31 maja 1980 r., red. Jan Pacławski, Tadeusz Ulewicz, „Rocznik Świętokrzyski” 1981, t. 9, s. 79.

${ }^{32}$ Aleksander Brückner, Dzieje kultury polskiej, t. 2 Warszawa 1958, s. 203; W. Dworzaczek, Hetman..., s. 278; Stanisław Kot, Polska złotego wieku a Europa. Studia i szkice, Warszawa 1987, s. 205; H. Barycz, Różanka (Rosarius)..., s. 431.

33 J. Lachs, Polscy uczniowie..., s. 23.

${ }^{34}$ H. Barycz, Różanka (Rosarius)..., s. 431; idem, Saga..., s. 408.

${ }^{35}$ H. Barycz, Różanka (Rosarius)..., s. 431; idem, Saga..., s. 437.

36 J. Lachs, Ephorinus i Różanka..., s. 193; H. Barycz, Różanka (Rosarius)..., s. $431-432$.

${ }^{37}$ J. Lachs, Kronika..., s. 138.

38 J. Lachs, Ephorinus i Różanka..., s. 192; Kraków stary i nowy: dzieje kultury, red. Janina Bieniarzówna, Kraków 1968, s. 111; H. Barycz, Różanka (Rosarius)..., s. 432; Zdzisław Noga, Krakowska rada miejska w XVI wieku: studium o elicie władzy, Kraków 2003, s. 133; i dem, Urzędnicy miejscy Krakowa, cz. 2: 1500-1794, Kraków 2008, s. 43; Poczet soltysów, wójtów, burmistrzów i prezydentów miasta Krakowa: (1228-2010), red. Bogdan Kasprzyk, Kraków 2010, s. 501. 
kę wprowadził Stanisław Myszkowski, wojewoda krakowski³ ${ }^{39}$ Od 1563 r. należał bowiem do najważniejszych członków kalwińskiego zboru w Krakowie, gdzie prym wiedli bogaci i wykształceni mieszczanie. Można przypuszczać, że odszedł od kościoła rzymskiego pod wpływem swego przyjaciela Krzysztofa Trecego, jednego z najważniejszych zwolenników Jana Kalwina $^{40}$. W 1565 r. został świeckim seniorem zboru, starał się o uzyskanie odpowiedniego lokalu na jego działalność i otworzenie szkoły. W $1570 \mathrm{r}$. udało się zakupić kamienicę zwaną „Bróg” przy ul. św. Jana pod numerem 6. Sam jednak, na tle innych darczyńców, do zorganizowanej zbiórki na ten cel dołożył niewielką kwotę $16 \mathrm{zt}^{41}$. Wspólnie z pisarzem miejskim Stanisławem Aichlerem ${ }^{42}$ i krakowskim ławnikiem Janem Wunsamem ${ }^{43}$ angażował się w działania na rzecz jedności wśród różnowierców. Grupa ta wraz z kalwińską szlachtą wezwała do Krakowa na wspólny synod starszych braci czeskich, aby nie dopuścić do rozbicia jedności zboru ${ }^{44}$. W kwietniu 1570 r. w Sandomierzu podczas synodu zjednoczeniowego, wraz z rajcą krakowskim Danielem Chroberskim ${ }^{45}$ i Krzysztofem Trecy, aktywnie reprezentował krakowską wspólnotę. Był członkiem rady powołanej na synodzie, która miała ocenić konfesję ,wiary powszechnej kościołów chrześcijańskich polskich”. W maju 1570 r. złożył podpis pod konsensem sandomierskim ${ }^{46}$. Bez wątpienia był wybitnym członkiem zboru, co potwierdza opinia biskupa warmińskiego kardynała Stanisława Hozjusza, czołowego przedstawiciela

${ }^{39}$ Janina Bieniarzówna, Jan M. Małecki, Dzieje Krakowa, t. 2: Kraków w wiekach XVI-XVIII, Kraków 1984, s. 138; Z. Noga, Krakowska..., s. 184.

${ }^{40}$ H. Barycz, Różanka (Rosarius)..., s. 432. Obydwaj, Różanka i Trecy, występują w spisie heretyków z parafii Mariackiej z 1568 r., W. Urban, Heretycy..., s. 172.

${ }_{41}$ Wojciech Węgierski, Kronika Zboru Ewangelickiego Krakowskiego, Kraków 2007, s. 63, 65; Adam Chmiel, Domy krakowskie. Ulica św. Jana, cz. 2: Liczby or. parzyste (2-32), Kraków 1924, s. 128; H. Barycz, Różanka (Rosarius)..., s. 432; idem, Saga..., s. 436.

${ }^{42}$ Krystyna Pieradzka, Aichler Stanisław, [w:] PSB, t. 1, Kraków 1935, s. 33-34.

${ }^{43}$ W. Urban, Heretycy..., s. 170.

${ }^{44}$ Halina Kowalska, Reformacja w Krakowie w czasach Jana Kochanowskiego, [w:] Cracovia litterarum: kultura umystowa i literacka Krakowa i Małopolski w dobie Renesansu: księga zbiorowa Międzynarodowej Sesji Naukowej w czterechsetlecie zgonu Jana Kochanowskiego (w Krakowie, 10-13 października 1984 r.), red. Tadeusz Ulewicz, Wrocław 1991, s. 256.

${ }^{45}$ Kazimierz Lepszy, Chroberski Daniel, [w:] PSB, t. 3, Kraków 1937, s. 446.

${ }^{46}$ W. Węgierski, Kronika..., s. 66; H. Barycz, Różanka (Rosarius)..., s. 432; J. Lachs, Ephorinus i Różanka..., s. 196; H. Kowalska, Reformacja w Krakowie..., s. 266. 
ruchu kontrreformacyjnego, który uważał Różankę za jednego z najważniejszych protestanckich działaczy w Krakowie ${ }^{47}$.

Majątek Stanisława Różanki był, nawet jak na krakowskie warunki, imponujący. Dochodził do niego latami. Już w 1558 r. posiadał niemałe kościelne beneficja: psałterię katedralną w Krakowie, kanonię sandomierską oraz probostwo w Sobótce. W 1559 r. otrzymał od Jana Tarnowskiego dożywotni zastaw na wójtostwo w Gniewczynie, które 6 lat później weszło na stałe do Różankowego majątku. Tytułem zastawu trzymał wsie szlacheckie, m.in. Krzysztoporzyce od Jana Krzysztoporskiego. W 1560 r. po spłacie wierzycieli i rodzeństwa przejął spadek po ojcu, w tym dom przy ulicy Floriańskiej (pod dziesiejszym numerem 36). Rok później po ślubie z Brygidą jego majątek powiększył się o kamienicę przy ulicy Szpitalnej. W 1565 r. kupił, a potem rozbudował kamienicę przy Rynku (obecnie numer 28) przylegającą do znanej nieruchomości „pod Baranami”48. Zamożność pozwalała mu na bogaty wystrój mieszkania w obrazy, naczynia orientalne, makaty, a także gromadzenie ksiąg, map, numizmatów, biżuterii i kamieni szlachetnych $^{49}$. Spadkobiercom miał zostawić majątek o wartości ok. 15000 złotych polskich ${ }^{50}$. Zmarł w Krakowie w czasie zarazy w pierwszej połowie stycznia $1572 \mathrm{r}^{51}$ Egzekutorami swojego testamentu sporządzonego w 1569 r. ustanowił lekarza Jakuba Krainę, Jana Gostniczyka, miejskiego pisarza Jana Pipana, Krzysztofa Trecego, Baltazara Grodeckiego i swojego brata Jana Różankę. „Doglądać” ich mieli panowie Mikołaj Ossoliński, Wojciech Wielicki i Walenty Różanka, drugi brat Stanisława ${ }^{52}$. Dobrze o Rosariusie świadczy zapisł dotyczący pogrzebu, który miał się odbyć „bez żadnej niepotrzebnej pompy na przedmieściu"53.

${ }^{47}$ H. Barycz, Różanka (Rosarius)..., s. 432; Halina Kowalska, Z dziejów reformacji w Krakowie, [w:] Szkice z dziejów Krakowa od czasów najdawniejszych do pierwszej wojny światowej, red. Janina Bieniarzówna, Kraków 1968, s. 196.

48 Józef Wawel-Louis, Przechadzka kronikarza po Rynku Krakowskim, Kraków 1890, s. 140; Adam Chmiel, Domy krakowskie. Ulica Floryańska, cz. 2, Kraków 1920, s. 148-149; H. Barycz, Różanka (Rosarius)..., s. 432; idem, Saga ..., s. 418, 433.

${ }^{49}$ Pełny tekst testamentu S. Różanki, [w:] J. Lach s, Kronika ..., dod. I, s. 163-168.

${ }^{50}$ Bartosz Paprocki, Herby rycerstwa polskiego, t. 1-3, Kraków 1858, s. 899; H. Barycz, Różanka (Rosarius)..., s. 432; J. Bieniarzówna, J. M. Małecki, Dzieje Krakowa..., s. 139-140; Z. Noga, Krakowska..., s. 222, 237.

${ }^{51}$ Historia nauki polskiej, t. 6, s. 576; H. Barycz, Różanka (Rosarius)..., s. 433; idem, Saga..., s. 445.

${ }^{52}$ J. Lachs, Kronika..., s. 163.

${ }^{53}$ Ibidem. 
Stanisław Różanka był człowiekiem zdolnym, a przy tym gorliwym w zdobywaniu wiedzy i poszerzaniu swoich horyzontów, humanistą, rajcą i burmistrzem, cenionym lekarzem ${ }^{54}$. Współczesny mu krakowski kanonik Stanisław Górski napisał anonimową biografię Stanisława Różanki ${ }^{55}$. Był on także bohaterem wesołej facecji: „Jedna pani uskarżała się przed doktorem [S. Różanka], że już w starości olsnęła [oślepła], a on rzekł: Tym lepiej, mości pani, że waszmość nie ujrzysz dyabła przy śmierci"56. Część badaczy sugeruje, że poeta Krzysztof Kobylieński (ok. 1520-1565) zadedykował mu swoje dzieło z 1558 r. Eqvitis Poloni, Variorvm Epigrammatvm Ad Stanislavm Rozimontanvm Libellvs, lecz H. Barycz przekonująco wyjaśnia, że z pewnością chodziło o zupełnie inną osobę ${ }^{57}$. Natomiast dzieło Dominika de Raygozy Clarissimi Doctoris Dominici Libellus Utilissimus, de Vrinarum Significatione, Olim Desideratus... wydał Stanislaus Rozatus Magister Artium Salutem, a więc nie omawiany Rosarius, jak chcieli widzieć niektórzy naukowcy ${ }^{58}$. Obydwu dzieł na próżno zresztą szukać w opisywanych inwentarzach, a raczej trudno sobie wyobrazić, żeby zabrakło ich w tak licznym zbiorze, gdyby były powiązane z Rosariusem.

Rosarius utrzymywał stosunki z elitą intelektualną miasta i państwa. Już jako młody człowiek zyskał uznanie w oczach biskupa krakowskiego Andrzeja Zebrzydowskiego i rodziny Tarnowskich. Był wyróżniającym się

${ }^{54}$ Niektórzy badacze sugerują nobilitację Różanki, J. Bieniarzówna, J. M. Małecki, Dzieje Krakowa..., s. 216; Kazimiera Maleczyńska, Z dziejów księgozbiorów mieszczańskich $w$ Polsce 1506-1572, Wrocław 1991, s. 28. Fakt ten znajduje potwierdzenie w najnowszych badaniach, Album armorum nobilium Regni Poloniae XV-XVIII saec.: herby nobilitacji i indygenatów XV-XVIII w., wstęp, oprac. i edycja Barbara Trelińska, Lublin 2001.

${ }^{55}$ Henryk Barycz, Pięćdziesiąt lat „Polskiego Stownika Biograficznego”: jego narodziny - trudne początki - perspektywy rozwoju, „Biuletyn Biblioteki Jagiellońskiej” 1988, R. 38, s. 192.

${ }^{56}$ Ambroży Grabowski, Starożytności historyczne polskie, czyli Pisma i pamiętniki do dziejów dawnej Polski, listy królów i znakomitych mężów, przypowieści, przysłowia i t.p., t. 1, Kraków 1840, s. 377; Dawna facecja polska, oprac. Julian Krzyżanowski i Kazimiera Żukowska-Bilip, Warszawa 1960, s. 281.

${ }^{57}$ Christophori Kobilienski, Eqvitis Poloni, Variorvm Epigrammatvm Ad Stanislavm Rozimontanvm Libellvs, Cracoviae Lazarvs Andreæ Excvdebat, 1558; H. Barycz, Saga ..., przyp. 2, s. 402-403.

${ }^{58}$ Dominicus de Raygoza (Dominik Raygoza), Clarissimi Doctoris Dominici Libellus Utilissimus, de Vrinarum Significatione, Olim Desideratus..., Cracoviae 1559. Egzemplarz przechowywany w bibliotece Uniwersytetu Kijowskiego nosi dedykację manu Rosati Scripta: „Excellen. D. Antonio Schnebergero Tigurino Med. Doctori DD”, Teodor Wierzbowski, Bibliographia Polonica XV ac XVI ss: Vol. 2, continens numeros 801-2000, Varsovia 1891, poz. 1374, s. 108. 
działaczem kalwińskim. Do kręgu jego przyjaciół należeli m.in.: Szymon Marycjusz, Krzysztof Trecy, kalwinista, podskarbi koronny Hieronim Bużeński ${ }^{59}$, doktor medycyny i teologii, humanista Antoni Schneeberger ${ }^{60}$ i pisarz żup wielickich Andrzej Szadkowski ${ }^{61}$. Przyjaciele z włoskich lat Andrzej Patrycy Nidecki i Stanisław Fogelweder, będąc sekretarzami królewskimi, utrzymywali kontakty z Różanką ${ }^{62}$. Być może pod jego wpływem pisarz sądu wyższego prawa niemieckiego na krakowskim zamku Bartłomiej Groicki ${ }^{63}$ dedykował swoje dzieło Artykuły Prawa Maydeburskiego, Ktore zowa Speculum Saxonum Janowi Tarnowskiemu ${ }^{64}$. Osobowość Stanisława Różanki, jego zainteresowania medyczne i humanistyczne, a także ludzie, wśród których się obracał, przekładają się na kształt jego wyjątkowego zbioru ksiąg i rękopisów.

Spis majątku Rosariusa sporządzono dwukrotnie. Po raz pierwszy spisano jego dobra doczesne w kwietniu 1572 r. ${ }^{65}$ Jedenaście lat później ponownie dokonano zestawienia dobytku. Przyczyna tego była w pewnej mierze kryminalna. Otóż w 1580 r. uprowadzono z dworu K. Trecego małoletnią córkę Różanki Annę. Za tym aktem bezprawia stał Jan Stadnicki, brat Stanisława (zwanego diabłem łańcuckim), który chciał połączyć węzłem małżeńskim Annę z Janem Młodnickim, szlechetką zależnym od Stadnickich, a rzecz dotyczyła oczywiście majątku, który miała odziedziczyć córka doktora. Finał tej sprawy miał miejsce przed krakowskim sądem trzy lata później ${ }^{66}$. W czerwcu 1583 r. sąd dokonał komisyjnego spisu całego Różankowego majątku, w tym ksiąg i rękopisów ${ }^{67}$. Dzięki temu dysponujemy aż dwoma inwentarzami obejmującymi księgozbiór jednego właściciela, co zdarza się niezwykle rzadko.

\footnotetext{
${ }^{59}$ Stanisław Bodniak, Bużeński Hieronim, [w:] PSB, t. 3, Kraków 1937, s. 156.

${ }^{60}$ Leszek Hajdukiewicz, Schneeberger (Schneberger) Anton, [w:] PSB, t. 35, Warszawa 1994, s. 569.

${ }^{61}$ Historia nauki polskiej, t. 6, s. 576; S. Kot, Polska..., s. 205, 473; H. Barycz, Różanka (Rosarius)..., s. 432.

${ }^{62}$ S. Łempicki, Renesans..., s. 190.

${ }^{63}$ Karol Koranyi, Michał Patkaniowski, Groicki (Grodzicki) Bartłomiej, [w:] PSB, t. 8, Wrocław 1959-1960, s. 628.

${ }^{64}$ Bartłomiej Groicki, Artykuły Prawa Maydeburskiego, Ktore zowa Speculum Saxonum, Z Lacinskiego Języka na Polski przełożone y znowu Drukowane, Roku 1559, w Krakowie: Drukował Lazarz Andrysowic, 1559; Obrońcy języka polskiego: wiek XVXVIII, oprac. Witold Taszycki, Wrocław 1953, s. 124-127.

${ }^{65}$ ANK, Akta miasta Krakowa, rkps 184 (Adv. Crac.), s. 871-889.

${ }^{66}$ H. Barycz, Saga..., s. 447-451.

${ }^{67}$ ANK, Akta miasta Krakowa, rkps 202 (Adv. Crac.), s. 794-811.
} 
Księgozbiór Rosariusa zyskał uznanie w oczach wielu badaczy podnoszących nie tylko ilość, ale także dobór i różnorodność dzie ${ }^{68}$. Trzecia część całego zbioru to dzieła medyków starożytnych i komentarze do nich oraz najnowsze prace XVI-wiecznych lekarzy. Szeroko rozumiane księgi humanistyczne, których autorami byli starożytni klasycy, krytyczne komentarze do nich oraz pisma renesansowych humanistów to także blisko trzecia część tej biblioteki. Inwentarze pokazują wiele takich dzieł z zakresu filozofii, filologii klasycznej, prawa i historii. Mało natomiast znalazło się w jego bibliotece pozycji z literatury pięknej, z czego można wysnuć wniosek, że nie leżała ona $\mathrm{w}$ kręgu zainteresowań Różanki ${ }^{69}$. Pamiętać jednak należy, iż publikacje z tego zakresu stanowiły nikły procent ówczesnej produkcji wydawniczej i być może stąd tak niewiele $\mathrm{z}$ nich znajduje się $\mathrm{w}$ omawianym zbiorze. Ważną jego część stanowią dzieła o tematyce religijnej. Zastanawia także znikoma liczba polskich tytułów, które stanowią tylko ok. 6\%. Chociaż księgozbiór zaczął gromadzić już w czasie studiów w Krakowie, to jednak wydaje się, że kluczowym momentem dla ukształtowania się Różanki-bibliofila był pobyt w Italii. Do końca życia powiększał swoją kolekcję. Różankę interesowała nie tylko medycyna czy humaniora, ale także botanika, zagadnienia przyrodnicze, czy też geografia. Zakupione książki opisujące Italię prawdopodobnie wykorzystywał podczas swoich wędrówek ${ }^{70}$. W Padwie zdobył bowiem nie tylko rozległą wiedzę w duchu renesansowego humanizmu, ale także uległ urokowi antycznej przeszłości. Znając język włoski, mógł swobodnie poznawać kulturę starej i współczesnej Italii. W Krakowie książki kupował za pośrednictwem księgarza Jana Thenauda, także kalwinisty, oraz swojego przyjaciela Krzysztofa Trecego, który często podróżując po Europie, mógł realizować Różankowe zamówienia ${ }^{71}$. Przy-

${ }^{68}$ A. Brückner, Dzieje..., s. 200; H. Barycz, Rozwój nauki..., s. 69; idem, Historia Uniwersytetu Jagiellońskiego w epoce humanizmu, Kraków 1935, s. 713; Kraków stary i nowy..., s. 130-131; Historia nauki polskiej, t. 6, s. 576; K. Maleczyńska, Z dziejów..., s. 86. Badaczka ta dokonała porównania księgozbioru z innymi renesansowymi mieszczańskimi bibliotekami. Praca ta jest tym bardziej cenna, że oparta na dwóch pełnych inwentarzach rękopiśmiennych, a nie częściowych opublikowanych przez J. Lachsa.

${ }^{69}$ Według H. Barycza w bibliotece Różanki jest ,dokument” Carmen macaronicum de eligendo vitae genere J. Kochanowskiego ,,ale nie wiadomo, czy podarowany przez autora, czy też w rękopiśmiennym odpisie”, wydaje się jednak, że można to rozpatrywać tylko w kategoriach hipotezy, ANK, Akta miasta Krakowa, rkps 184 (Adv. Crac.), s. 888; H. Barycz, Z zaścianka..., s. 165; idem, Saga..., s. 439.

${ }^{70}$ Idem, Różanka (Rosarius)..., s. 431; idem, Saga..., s. 438.

${ }^{71}$ Monika Jaglarz, Księgarstwo krakowskie XVI wieku, Kraków 2004, s. 64, 123 , $143-144$. 
puszczalnie dostawał także książki jako podarki ${ }^{72}$. Księgozbiór, zbiór map i kolekcję numizmatyczną zapisał swojemu bratu Walentemu ${ }^{73}$, ale zalecił, aby z biblioteki mogli korzystać inni uczący się ${ }^{74}$. Zdaniem H. Barycza wynikało to z poznania włoskich zwyczajów i chęci przeniesienia ich na krakowski grunt ${ }^{75}$.

Stanisław Różanka studiował w Padwie nowoczesną anatomię, słuchając wykładów jej czołowych przedstawicieli: Andreasa Vesaliusa (1514-1564), Matteo Realdo Colomba (ok. 1516-1559), Gabrielle Falloppio (15231562). O dogłębnym zainteresowaniu Rosariusa ludzkim ciałem świadczy fakt posiadania szkieletu ${ }^{76}$. W części medycznej księgozbioru znajdowały się klasyczne dzieła Galena i Hipokratesa oraz oczywiście komentarze do nich. Wśród wielu pozycji dotyczących medycyny warto wymienić kilku autorów, których prace znalazły się w bibliotece Rosariusa: Giovanni Battista da Monte (1498-1551), Antonio Musa Brasavola (1500-1555), Pietro Andrea Mattioli (1501-1577), Girolamo Cardano (1501-1576), Conrad Gesner (1516-1565), Girolamo Fracastoro (ok. 1476/1478-1553), Paracelsus (1493/1494-1541) ${ }^{77}$, Giovanni Argenterio (1513-1572), Taddeo Duno (1523-1613), Jean Fernel (1497-1558), Giovanni da Vigo (1450-1525), Georg Agricola (1494-1555) i wielu innych. Z polskich dzieł medycznych zwraca uwagę De arte sphygmica padewskiego profesora medycyny Józefa Strusia (1510-1568), którego pionierskie badania tętna zapewniły mu trwałe miejsce w historii medycyny. Warto też zauważyć Walentego z Lublina jako cenionego wydawcę kilkunastu dzieł medycznych Giovanniego Battisty da Monte, z których pięć znalazło się w księgozbiorze Różanki. Dla medycyny ważne były nauki przyrodnicze, stąd obecność dzieł Theophrasta, Pliniusza, Leonharta Fuchsa (1501-1566) oraz prac astronomów Joannesa de Monte Regio (1436-1476), Georga Purbacha (1423-1461) i Johannesa de Sacrobosco (ok. 1195-1256).

${ }^{72}$ H. Barycz, Saga..., s. 432.

73 J. Lachs, Kronika..., s. 166. Stanisław przeżył o dwa miesiące młodszego brata, który zmarł w listopadzie 1571 r., H. Barycz, Różanka Walenty..., s. 434.

${ }^{74}$ J. Lachs, Kronika..., s. 166.

${ }^{75}$ H. Barycz, Historia Uniwersytetu..., s. 714.

${ }^{76}$ ANK, Akta miasta Krakowa, rkps 184 (Adv. Crac.), s. 875.

77 Zdaniem P. Rybickiego Stanisław Różanka jako lekarz był zwolennikiem Paracelsusa (1493/1494-1541), ojca nowożytnej medycyny, twórcy nowego kierunku w medycynie opartego na teorii trzech składników: siarki, rtęci, soli, Paweł Rybicki, Odrodzenie, [w:] Historia nauki polskiej, t. 1, red. Bogdan Suchodolski, Wrocław 1970, s. $302-303$. 
W zbiorze bibliotecznym Rosariusa znalazła się zarówno Geographia Ptolemeusza $^{78}$, jak i oprawione $\mathrm{w}$ formie kodeksu mapy tworzące atlas facti$c e$, atlas sztuczny, opisane w inwentarzu jako Imagines Geographicae ${ }^{79}$. Był właścicielem druków opisujących Italię i jej zabytki, które wykorzystywał przy zwiedzaniu ${ }^{80}$. Księgi te uzupełniały kolekcję map naklejonych na płótno, których posiadał $27^{81}$. O jego zainteresowaniach poznawczych świadczy fakt, że zaliczał się do nielicznych posiadaczy globusa ${ }^{82}$, którego zakup i sprowadzenie do Krakowa pociągały za sobą zapewne niemałe koszty.

Zainteresowanie starożytnością w oczywisty sposób przełożyło się na zawartość jego księgozbioru. Różankę pociągała filozofia, szczególnie zgłębiany w Padwie arystotelizm, stąd liczne dzieła Arystotelesa oraz prace zawierające komentarze do Stagiryty różnych autorów, m.in. Simpliciusa (ok. 470-560), Joannesa Philoponusa (ok. 490-570), Juana Luisa Vivesa (1493-1540), Marsilio Fichino (1433-1499), Francesca Robortella (1516-1567) i Erazma z Rotterdamu (1466-1536). Różankę zajmował grecki antyk, dlatego też nie dziwi blisko 40 dzieł w tym języku. Korzystał z prac podstawowych, jak gramatyki i słowniki takich autorów, jak Philip Melanchton (1497-1560), Theodorus Gaza (1410-1475) oraz Nicolaus Clenardus (1495-1542). Z piśmiennictwa greckiego posiadał niewiele dzieł z literatury pięknej, chciaż pojawiają się pojedyncze prace Ezopa, Pindara i Ajschylosa. Natomiast zgromadził liczne dzieła historyczne i geograficzne autorstwa Plutarcha, Hezjoda, Tukidydesa, Ksenofonta, Appiana, Pauzaniasza i późniejszego Euzebiusza z Cezarei. W tak znakomitej bibliotece nie mogło zabraknąć dzieł wielkich greckich mówców: Demostenesa, Isokratesa oraz Eschinusa. Wprawdzie greka pojawia się jako język niektórych druków (także medycznych), ale najczęściej są to prace dwujęzyczne grecko-łacińskie, trudno więc jednoznacznie przypisać Różance znajmość greki. Można natomiast zakładać, że swobodnie posługiwał się językiem włoskim. Nie był to wprawdzie liczny dział w bibliotece Różanki, obejmował

${ }^{78}$ ANK, Akta miasta Krakowa, rkps 184 (Adv. Crac.), s. 876.

${ }^{79}$ ANK, Akta miasta Krakowa, rkps 184 (Adv. Crac.), s. 879.

${ }^{80} \mathrm{~Np}$. Tipographia antiqua Romae Bartholomei Mariani, ANK, Akta miasta Krakowa, rkps 184 (Adv. Crac.), s. 883, rkps 202 (Adv. Crac.), s. 802.

${ }^{81}$ ANK, Akta miasta Krakowa, rkps 184 (Adv. Crac.), s. 875. H. Barycz interpretuje zapis in pariete mappae 3 (ANK, Akta miasta Krakowa, rkps 184, Adw. Crac., s. 876) jako trzy mapy ścienne, co wydaje się wątpliwe, H. Barycz, Różanka (Rosarius)..., s. 439.

${ }^{82}$ ANK, Akta miasta Krakowa, rkps 184 (Adv. Crac.), s. 875. Oprócz S. Różanki globusy posiadali: J. Łaski, J. Dantyszek i późniejszy J. Brożek, Romuald Wróblewski, Podróże jako źródło wiedzy o Ameryce, „Odrodzenie i Reformacja w Polsce” 1972, t. 17, s. 85 . 
niewiele ponad dziesięć pozycji, ale znalazły się tam dzieła Giovanniego Boccaccia i Niccolo Macchiavellego, a także książki medyczne, prawnicze czy historyczne.

Księgozbioru Rosariusa nie można by nazywać w pełni renesansowym, gdyby zabrakło w nim dzieł Erazma z Rotterdamu. Nie zaliczał się wprawdzie do największych zbieraczy prac wielkiego Rotterdamczyka, ale w swojej bibliotece $\mathrm{z}$ pewnością posiadał ok. 12 jego ksiąg ${ }^{83}$.

Bardzo ważne miejsce w bibliotece Różanki zajmują księgi religijne, które stanowią ponad 10\%. Rzuca się w oczy zdecydowana przewaga literatury kalwińskiej (choć znajdziemy pracę Marcina Lutra De Captivitate Babylonica). Autorami ksiąg religijnych w opisywanym zbiorze byli: F. Melanchton, Jean Calvin (1509-1564), Theodore de Beze (15191605), Jan Utenhove (1516-1566), Josias Simmler (1530-1576), Wolfgang Musculus (1497-1563). Z polskich akcentów warto zwrócić uwagę na dzieło Jana Łaskiego mł. (1499-1560) i pisma go potępiające kardynała Stanisława Hozjusza (1504-1579) oraz na listy kalwińskich działaczy zuryskich do polskich zborów. Wydaje się, że za inwentarzowym zapisem Biblia Polonica kryje się, jakże ważna dla XVI-wiecznych protestantów, Biblia brzeska, wydany z funduszy Mikołaja Radziwiłła Czarnego w 1563 r. przekład całości Pisma Świętego na język polski dokonany przez polskich protestantów (zwana także Biblią Radziwiłłowską lub Biblią pińczowską).

Bardzo skromne opisy inwentarzowe często skazują na domysły w kwestii identyfikacji poszczególnych druków. Można przypuszczać, że spisujący inwentarze miejscy notariusze w obu przypadkach nie widzieli stron tytułowych, lecz zapisywali to, co podyktował inny urzędnik lub ktoś ze służby. Świadczą o tym błędy w spisywanych nazwiskach i tytułach, a w niektórych przypadkach daje się zauważyć zapis fonetyczny poszczególnych słów. Przykładowo w inwentarzu z rkps 184 (s. 883) istnieje taki opis dotyczący Ajschylosa: Eskini tragediae septe[m]. Z kolei w rkps 202 (s. 804) zapis tego dzieła wygląda następująco: Aeschilii Tragediae septem $^{84}$. Podobny problem pojawia się z N. Macchiavellim. W rkps 184 występuje w formie Discursi Nicolai Machabei in Livu[m] Italice (s. 882) oraz Historiae Machabelli Italice (s. 882). Ale piszący inwentarz z rkps 202 podał inne formy nazwiska: Dioscorti di Nicola Machievelli sup[er] Livium

${ }^{83}$ W. Szelińska, opierając się na inwentarzach opublikowanych przez J. Lachsa, oszacowała erazmiański zbiór na ponad 15 egzemplarzy, Wacława Szelińska, Książka Erazma z Rotterdamu w środowisku krakowskim w XVI wieku, Kraków 1990, s. 202.

${ }^{84} \mathrm{Za}$ pomoc w analizie obu inwentarzy serdecznie dziękuję Panu dr. Andrzejowi Obrębskiemu. 
(s. 804) oraz Historiae di Nic[co]lo Machiavelli (s. 804). Inwentarze różnią się także kolejnością spisywanych dzieł. Ten z rkps 184 zawiera pełniejsze opisy, a spisujący częściej stosuje skróty wyrazów. Spis z rkps 202 jest dużo bardziej oszczędny i podaje mniej informacji, np. Plutarchus (s. 798), podczas gdy rkps 184 notuje dwa dzieła tego autora: Plutarchi Illustr[isi]m [orum] Viroru [m] vitae (s. 877) i Apophtegmata Graeca Plutarchi (s. 888).

Niestety bardzo oszczędne i nierzadko mylące zapisy nie pozwalają na pełne porównanie zawartości obu spisów. Inwentarz z 1583 r. zawiera 394 pozycje, o dziesięć więcej niż ten z 1572 r. Prawdopodobną przyczyną mogło być pożyczanie książek, udostępnianie swojej biblioteki innym czytelnikom. W kwietniu 1572 r. niektóre pozycje mogły być po prostu wypożyczone, a w późniejszym okresie czytelnicy oddawali je i stąd ta, niewielka w gruncie rzeczy, różnica. Poźniejszy spis zawiera m.in. więcej dzieł Boccaccia, Cicerona, Theophrasta, pojawiły się tomy Alcinousa, Terentiusa i Catullusa. Z autorów współczesnych godny uwagi jest Carlo Sigonio i jego praca De antiquo iure Italiae... Odnotowano także nowe polonica: Wyznanie wiary Stanisława Orzechowskiego, Sprawa rycerska Marcina Bielskiego i Processus Juris autorstwa Grzegorza z Szamotuł. Jednak niektórych pozycji z rkps 184 nie znajdziemy w rkps 202. Takim przykładem jest Chronica Polonica, której na próżno szukać w drugim spisie.

Stanisław Różanka był właścicielem jednej z największych bibliotek renesansowego Krakowa. Wprawdzie H. Barycz szacował, że zbiór ten liczył ok. 500 dzie ${ }^{85}$, to jednak każdy z inwentarzy wykazuje na niemal 400 ksiąg i rękopisów. Nie zmienia to faktu, że i tak był to imponujący księgozbiór. Nie wiemy, czy Rosarius przejął lub kupił jakiś inny, większy księgozbiór (np. po teściu Wojciechu Krainie). Jako człowiek zaradny, niezależny finansowo mógł spełniać swoje bibliofilskie pasje bez żadnych ograniczeń, o czym świadczy bogactwo całego domowego inwentarza. Biblioteka Różanki na tle innych bibliotek XVI-wiecznych wypada bardzo okazale. Profesor Uniwersytetu Krakowskiego, sekretarz królewski i dyplomata Mikołaj Czepiel (zm. 1518) dysponował biblioteką liczącą co najmniej 250 dzieł $^{86}$. Znacząco większy zbiór, liczący ok. 1000 dzieł w 250 woluminach, posiadał profesor i rektor krakowskiej uczelni, astronom Maciej Miechowita (zm. 1523) ${ }^{87}$. Bibliotekę kolejnego profesora, sławnego grecysty Stanisława

${ }^{85}$ H. Barycz, Saga..., s. 434.

${ }^{86}$ Anna Lewicka-Kamińska, Renesansowy księgozbiór Mikołaja Czepla w Bibliotece Jagiellońskiej, Wrocław 1956, s. 26.

${ }^{87}$ Leszek Hajdukiewicz, Maciej z Miechowa, [w:] PSB, t. 19, Wrocław 1974, s. 32. 
Grzepskiego (zm. 1570) szacuje się na ok. 350 pozycji ${ }^{88}$. Księgozbiory kościelnych dostojników były niekiedy bardzo obszerne. Biskup krakowski, kanclerz uniwersytetu Piotr Tomicki (zm. 1535) miał do dyspozycji bibliotekę obejmującą 400-500 dzieł ${ }^{89}$. Niezwykle okazały księgozbiór, liczący ponad 1400 dzieł był własnością płockiego biskupa, kanclerza koronnego i dyplomaty Piotra Dunin Wolskiego (zm. 1590) ${ }^{90}$. Hieronim Rozdrażewski, biskup włocławski i dyplomata (zm. 1600), posiadał w swoim zbiorze przynajmniej 680 dzieł $^{91}$.

Pod względem wielkości zupełnie inaczej kształtowały się księgozbiory mieszczańskie. Rodzinna biblioteka Decjuszów, gromadzona przez dwa pokolenia, składała się w 1580 r. z 450 dzieł ${ }^{92}$. Jan Góra (zm. 1597), prawnik i notariusz, rajca krakowski, średniozamożny mieszczanin, był posiadaczem $72 \mathrm{ksiąg}^{93}$. Inny prawnik z Krakowa, Mikołaj Bronowski, w 1585 r. posiadał księgozbiór liczący 115 dzieł w 130 tomach $^{94}$. Warto przytoczyć kilka przykładów z lekarskich księgozbiorów. I tak krakowski medyk Maciej z Krajny (zm. po 1546) był właścicielem 273 tomów ${ }^{95}$. Inwentarz biblioteki Dominika Drozdowskiego spisany w 1569 r. obejmował 70 dziel $^{96}$, a chirurga Jakuba Gaiera (z 1572 r.) tylko $19^{97}$ - i takie bowiem biblioteki trafiały się u lekarzy krakowskich. Warto wspomnieć jeszcze o zbiorze Erazma Lipnickiego liczącym 113 pozycji, w tym nieznaną ilość ksiąg po innym lekarzu Janie Antoninie z Koszyc. Wdowa po Lipnickim Urszula wyszła za mąż

${ }^{88}$ Henryk Barycz, Grzepski Stanisław, [w:] PSB, t. 9, Wrocław 1961, s. 101; Anna Lewicka-Kamińska, Biblioteka Jagiellońska w latach 1492-1655, [w:] Jerzy Zathey, Anna Lewicka-Kamińska, Leszek Hajdukiewicz, Historia Biblioteki Jagiellońskiej, t. 1: 1364-1775, red. Ignacy Zarębski, Kraków 1966, s. 156; L. Hajdukiewicz, Biblioteka Stanisława Grzepskiego, „Przegląd Geodezyjny” 1967, R. 39, nr 5, dod., s. 17.

${ }^{89}$ Leszek Hajdukiewicz, Księgozbiór i zainteresowania bibliofilskie Piotra Tomickiego na tle jego działalności kulturalnej, Wrocław 1961, s. 139.

90 Volsciana: katalog renesansowego księgozbioru Piotra Dunin-Wolskiego, biskupa płockiego, oprac. Andrzej Obrębski, Kraków 1999, s. 5.

${ }^{91}$ Ludwik Grzebień, Biblioteka biskupa Hieronima Rozrażewskiego (1542-1600), „Archiwa, Biblioteki i Muzea Kościelne” 1971, t. 22, s. 94.

${ }_{92}$ Włodzimierz Budka, Biblioteka Decjuszów, „Silva Rerum” 1928, t. 4, s. 112.

${ }^{93}$ Maria Jaroszyńska, Biblioteka Jana Góry rajcy krakowskiego z XVI w., ,Roczniki Biblioteczne" 1962, R. 6, z. 3/4, s. 2-3, 14.

94 Włodzimierz Budka, Biblioteka Mikołaja Bronowskiego, „Przegląd Biblioteczny" 1930, R. 4, s. 210.

${ }_{95}$ Leszek Hajdukiewicz, Jerzy Wiśniewski, Maciej z Krajny h. Topór, [w:] PSB, t. 19, Wrocław 1974, s. 22; L. Hajdukiewicz, Księgozbiór..., s. 141.

${ }^{96}$ K. Maleczyńska, $Z$ dziejów..., s. 28.

${ }^{97}$ Ibidem, s. 38. 
również za lekarza o imieniu Hilary, a spisany niedługo później inwentarz obejmował 226 tytułów ${ }^{98}$. Imponującym księgozbiorem mógł poszczycić się inny medyk Kasper Lindler z Poznania (zm. 1576), który był właścicielem 488 dziet $^{99}$.

Niestety dotychczas nie odkryto pozycji z księgozbioru Stanisława Różanki Rosariusa. Nie wiemy, co stało się z tą tak dużą biblioteką. W zbiorach Biblioteki Jagiellońskiej zidentyfikowano trzy dzieła, których właścicielem był Stanisław Różanka, lecz piszący się „Rosatus” ${ }^{100}$. W kwestii różnic między spisami skazani jesteśmy na domysły, dlaczego inwentarz z 1583 r. jest obszerniejszy. Być może część dzieł znajdowała się u osób, którym wypożyczył księgi, ale nie można wykluczyć też błędów spisujących. Ostateczny stan liczbowy biblioteki nie zmienia zasadniczo oceny tego zbioru. Tym bardziej że przeciętny księgozbiór lekarski liczył kilkadziesiąt dzieł ${ }^{101}$. Blisko 400 pozycji w inwentarzach stawia go w gronie największych renesansowych miłośników książek. Doktor medycyny i filozofii padewskiej promocji Stanisław Różanka Rosarius był człowiekiem o szerokich zainteresowaniach naukowych, niezamykającym się w kręgu spraw medycznych, zaangażowanym w sprawy religijne, a przy tym wytrawnym bibliofilem. Jego księgozbiór jest autentycznym pomnikiem kultury XVI-wiecznego Krakowa.

${ }^{98}$ Ibidem, s. 28.

${ }^{99}$ Maria Wojciechowska, Z dziejów książki w Poznaniu w XVI wieku, Poznań 1927, s. 106; K. Maleczyńska, Z dziejów..., s. 29.

${ }^{100}$ Dwa dzieła Arystotelesa składające się na introligatorski klocek odkryto w księgozbiorze kamedułów eremitów z krakowskich Bielan: Aristotelis Ethicorvm, Sive De Moribvs Ad Nicomachum filium libri x..., Basileae: (Ex Officina Barptholomaei Vesthemeri, IX 1545) oraz Aristotelous İthikōn Nikomacheiōn Vivlia Deka = Aristotelis De Moribvs Ad Nicomachvm Libri Decem [ed. Ioannes Stvrmius], Argentorati 1545 (BJ Cam. L. III). Natomiast w zbiorach Biblioteki Jagiellońskiej przechowywana jest praca Galenusa, Omnia Cl. Galeni Pergameni... Opera qvotqvot aput Graecos in hvnc vsqve diem extitervnt ...tum ipsam quoque Galeni uitam... depingens [T. V-VI, VII-VIII], Basileae M.D.XLII (BJ St. Dr. Cim. 8779).

${ }^{101}$ K. Maleczyńska, Z dziejów..., s. 28. 


\title{
Księgozbiór Stanisława Różanki według inwentarza z roku 1572 (Advocatialia Cracoviensia rkps 184) ${ }^{102}$
}

\author{
[...] Item libri. Primo in folio \\ 1 Gesneri Volumina $3^{103}$ \\ 2 Eusebii Historiae Ecclesiasticae Graece ${ }^{104}$ \\ 3 Joannis Argenterii De morbis ${ }^{105}$ \\ 4 Anthonii Musae super Galenu[m] Index ${ }^{106}$ \\ 5 Opera Galeni in septem Thomis ${ }^{107}$ albo Corrigis involuta \\ 6 Opera Galeni Graeca lingua in trib[us] thomis ${ }^{108}$ \\ 7 Eustratii in 10 libros Ar[istote]lis ${ }^{109}$ \\ 8 Raphaelis Volaterani Comme[n]tarior[um] volumen ${ }^{110}$ \\ 9 Chiliada Erasmi Rotterodami ${ }^{111}$ \\ 10 Inscriptiones totius vetustatis fere orbis ${ }^{112}$ \\ 11 Conciliator controversiar[um] $]^{113}$ \\ 12 Theodori Graeci Introductivae gra[m]matices ${ }^{114}$
}

${ }^{102} \mathrm{~W}$ objaśnieniach podaję edycje najbardziej zbliżone do bardzo oszczędnych zapisów w inwentarzach. W przypadku wielu podobnych wydań podaję przykładowe z okresu aktywności Stanisława Różanki.

${ }^{103}$ Conrad Gesner (Euonomus Filatrus, Euonymus Philiatrus) (1516-1565), szwajcarski lekarz, humanista, filozof, filolog, przyrodnik, bibliofil. Dzieła nie udało się zidentyfikować.

${ }^{104}$ Eusebius Caesariensis (Eusebius Pamphilus, Eusebio di Cesarea, Eusebios ho Pamphilos) (264-340), pisarz, teolog, historyk, biskup Cezarei w Palestynie. Prawdopodobnie: Ecclesiasticae Historiae: Eusebii Pamphilii Lib. X..., Lutetiae Parisiorum 1544.

${ }^{105}$ Giovanni Argenterio (Johann Argentier, Argenterius) (1513-1572), włoski lekarz, profesor medycyny. Prawdopodobnie: Ioannis Argenterii... De morbis, libri 14..., Florentiae 1556.

${ }^{106}$ Antonio Musa Brasavola (Antonius Musaeus Brasavolus) (1500-1555), włoski lekarz. Antonii Musae Brasavoli... Index refertissimus in omnes Galeni libros qui ex Juntarum tertia editione extant, Venetiis 1556.

${ }^{107}$ Claudius Galenus (Claudius Galenus Pergamenus, Galenus medicus, Galeno) (ok. 130200 p.n.e.), grecki lekarz, chirurg i filozof. Prawdopodobnie Claudii Galeni Pergameni... De Compositione Medicamentorvm Kata Genē Lib. VII, Basileae 1530.

${ }^{108}$ Claudius Galenus. Dzieła nie udało się zidentyfikować.

${ }^{109}$ Eustratius Episcopus Nicaenus (Eustrazio di Nicea) (ok. 1050-1120), arcybiskup Nicei, filozof, autor komentarzy do Arystotelesa. Prawdopodobnie: Eustratiou kai allōn tinon episēmōn hypomnèmata eis ta deka tōn tou Aristotelous èthikōn Nikomacheiōn biblia meta tou ypokeimenou. Eustratii et aliorum insignium peripateticorum commentaria in libros decem Aristotelis de moribus ad Nicomachum, vna cum textu suis in locis adiecto, [Venetiis 1536].

${ }^{110}$ Raffaele Maffei (Raffaello Volterrano, Volaterranus) (1455-1522), włoski uczony, humanista, tłumacz, komentator starożytnych autorów. Prawdopodobnie: Commentariorum urbanorum Raphaelis Volaterani, octo et triginta libri..., Basileae 1559.

${ }^{111}$ Erasmus Rotterdamus (Desiderius) (1466-1536). Wiele wydań, przykładowo: Chiliades Adagiorum..., Coloniae 1540.

${ }^{112}$ Inscriptiones sacrosanctae vetustatis non illae quidem Romanae, sed totius fere orbis summo studio ac maximis impensis terra marique conquisitae feliciter incipiunt, Ingolstadii 1534.

${ }^{113}$ Petrus de Abano (Pietro Albano, Petrus de Apono, Petrus Paduanus) (ok. 1250-1315), włoski lekarz, filozof, astrolog. Conciliator controversiarum, quae inter philosophos et medico versantur..., Venetiis 1565 .

114 Theodoros Gaza (Teodoro Gaza, Theodorus Gazes) (1410-1475), grecki humanista, filolog, uczestnik soboru florenckiego (1439). Prawdopodobnie: Theodori Gazae Thessalonicensis, Gramma- 
13 Nauka o prawdziweÿ i falsziweÿ pokuczie Wawrzincza z Przasnissa ${ }^{115}$

14 Biblia Polonica ${ }^{116}$

15 Melchioris Kling Co[m]mentaria ${ }^{117}$

16 Joannis Francisci Cornucopiae ${ }^{118}$

17 Chronographia Alexandri Sculteti ${ }^{119}$

18 Geographia Ptholomei ${ }^{120}$

19 Reginaldi Ecclesiasticae unitatis defensio ${ }^{121}$

20 Iudicia Astror[um] Albort Asni Itali ${ }^{122}$

21 Joannis Slaidani de Statu Religionis ${ }^{123}$

22 Thucididis de bello pellopo[n]nesiaco ${ }^{124}$

23 Consilia Montagnanae ${ }^{125}$

24 Diogenis Historiae Romanae Graeca lingua ${ }^{126}$

25 Lexicon Graecolatin[um $]^{127}$

ticae institutionis libri duo, nempe primus \& secundus sic translati per Erasmum Roterodamum, ac titulis \& annotatiunculis explanati, ut citra negotium \& percipi queant \& teneri..., Basel 1518 (lub inne wydanie).

115 Wawrzyniec Niezgoda z Przasnysza (zm. ok. 1566), działacz reformacyjny, kaznodzieja króla Zygmunta Augusta II. Náuká O prawdziwey y o fátszywey Pokućie..., b.m.w., 1559.

${ }_{116}$ Prawdopodobnie: Biblia swięta, tho iest, Księgi Starego y Nowego Zakonu, wlasnie z Zydowskiego, Greckiego, y Laćińskiego, nowo na Polski ięzyk z pilnośćia y wiernie wylożone, [Brześć Litewski] 1563.

${ }_{117}$ Melchior Kling (Melchior Clingius, Melchior Kling a Steynau) (1504-1571), niemiecki prawnik, profesor prawa kanonicznego. ... Melchioris Kling, .... In praecipuos, et eos qui ad usum forensem praecaeteris faciunt, secundi libri, antiquarum decretalium titulos, commentaria..., Francoforti 1550.

${ }^{118}$ Niccolo Perotti (Nicolao Perotto, Nicolaus Perotus Sypontinus) (1429-1480), włoski humanista, filolog. Prawdopodobnie: Joannis Francisci ... Tetrastichon in Cornucopiae Perottaei Laudem, etc..., Venetiis 1489.

${ }^{119}$ Alexander Scultetus (Alexander Sculteti) (ok. 1485-1564), historyk, kartograf, kanonik, kanclerz kapituły warmińskiej. Chronographia, sive, Annales omnium fere regum, principum, \& potentatuum: ab orbe co[n]dito, usq[ue] ad hunc annu[m] Domini. M.D. XLV..., Romae 1546.

${ }^{120}$ Claudius Ptolemaeus (Klaúdios Ptolemaîos) (ok. 100-170), matematyk, astronom, geograf, astrolog. Wiele wydań, przykładowo: Geographia Universalis, vetus et nova, complectens Claudii Ptolemaei Alexandrini enarrationis libros VIII..., Basileae 1545.

${ }^{121}$ Reginald Pole (Reginaldo Polo, Reginaldus Polus) (1500-1558), angielski kardynał, ostatni rzymskokatolicki arcybiskup Canterbury. Prawdopodobnie: Reginaldi Poli ... Pro Ecclesiasticae Unitatis defensione, libri quatuor..., Strasburg 1555.

122 Dzieła nie udało się zidentyfikować.

${ }^{123}$ Johannes Sleidanus (Giovanni Sleidano, Baptista Lasdenus) (1506-1556), historyk reformacji. Wiele wydań, przykładowo: De statu religionis et rei publicae Carolo V. Caesare commentarii, Argentorati Basileae 1556.

${ }^{124}$ Thucydides (Thoukydídes) (ok. 460-400 p.n.e.). Wiele wydan, przykładowo: Thucidydis Atheniensis historiographi De bello Peloponnensium Athenensiumque libri octo. Laurentio Valla interprete..., Coloniae 1550.

${ }^{125}$ Bartholomaeus Montagnana (Bartholomaeus de Montagna) (14??-1460), włoski medyk, profesor w Bolonii i Padwie. Prawdopodobnie: Bartholomaei Montagnanae consilia CCCV., in quibus agitur de universis fere aegritudinibus et ... curandi eas adhibetur modus, Venetiis 1565.

${ }^{126}$ Dzieła nie udało się zidentyfikować.

${ }^{127}$ Wiele wydań, być może: Lexicon Graecolatinvm denvo impressum, per vtriusq[ue] linguae doctos \& industrios uiros primum utiliter collectum..., Basileae 1548. 
26 Plutarchi Illustr[iu]m[orum] Viroru[m] vitae ${ }^{128}$

27 Simplici Co[m]mentarii in Phisica Ar[istote]lis ${ }^{129}$

28 Philoponi Co[m]mentaria in libros posterior[um] Ar[istote]lis ${ }^{130}$

29 De febribus Joannis Herculani ${ }^{131}$

30 Plinii S[e]c[un]di Historiar[um] libri ${ }^{132}$

31 Opera Ar[istote]lis in quinque Thomis ${ }^{133}$

32 Joannis Cantacuzaeni con[tra] Hae[re]sin Saracenor[um] lib[er] Graec[us] ${ }^{134}$

33 Almonii Com[m]e[n]taria Graeca in Ar[istotel] $\mathrm{em}^{135}$

34 Andreae Vesalii Epithomia Anathomiae ${ }^{136}$

35 Joa[n]nis Gramatici Co[m]mentaria Graeca in libros Ar[istote]lis ${ }^{137}$

36 Fra[n]cisci Vicomercati in 8 libros Ar[istote]lis Phisicos ${ }^{138}$

37 Eiusde[m] in Metheor[ologic]or[um] libros ${ }^{139}$

${ }^{128}$ Plutarchus Chaeronensis (Ploútarkhos, Lucjusz Mestrius Plutarchus) (ok. 50-120), grecki bibliograf, filozof. Wiele wydań, przykładowo: Plutarchi Chaeronei..., Vitae comparatae illustrium Virorum, Graecorum \& Romanorum..., Basileae 1564.

${ }^{129}$ Simplicius (Simplicius Cilicius, Simplicius Philosophus) (ok. 470-560), neoplatonik, komentator Arystelesa. Wiele wydan, przykładowo: Simplicii Commentarii in octo Aristotelis Physicae auscultationis libros..., Venetiis 1551.

${ }^{130}$ Ioannes Philoponus (Ioannes Alexandrensis, Ioannes Grammaticus) (ok. 490-570), chrześcijański filozof i teolog. Wiele wydań, przykładowo: Ioannis Grammatici Philoponi Alexandrei commentaria in libros posteriorum analiticorum Aristotelis..., Venetiis 1559.

${ }^{131}$ Ioannes Herculanus (Giovanii Arcolani, Arcolanus) (1390-1484), lekarz, filozof. Prawdopodobnie: De febribus Ioannis Herculani in Avicennae quarti canonis fen primam dilucida, atque optima expositio..., Venetiis 1552.

${ }^{132}$ Gaius Plinius Secundus (23-79), rzymski historyk. Prawdopodobnie: C. Plinii Secundi historiarum naturae libri XXXVII..., Parisiis 1532.

${ }^{133}$ Dzieła nie udało się zidentyfikować.

${ }^{134}$ Jan VI Kantakuzen (Iōannēs ST' Kantakouzēnos, Johannes Cantacuzenus) (1294/1295-1383), cesarz bizantyński w latach 1347-1354. Ioannis Cantacuzeni Constantinopolitani regis Contra Mahometicam fidem Christiana \& orthodoxa assertio; Adiecta est eadem graece scripta...; Contra Mahometicam fidem Christiana \& orthodoxa assertio; Contra Saracenorum haeresim pro christiana religione apologiae IIII; Kata tēs tōn sarakenōn haireseōs Apologiai 4., Basileae 1543.

${ }^{135}$ Identyfikacja niepewna. Przypuszczalnie Ammoniusz Hermiae (ok. 440-520), grecki filozof, autor komentarzy m.in. na temat Platona i Arystotelesa. Być może chodzi o dzieło: Ammōniou tou Hermeiou Eis tas tou Aristotelous Katēgorias hypomnēma. Ammonii Hermiae In praedicamenta Aristotelis commentarius, Venetiis 1546.

${ }^{136}$ Andreas Vesalius (Andreas Vessalius Bruxellensis, Andries van Wesel) (1514-1564), flamandzki lekarz, autor fundametalnych dzieł na temat anatomii człowieka. Wiele wydań, być może: Andreae Vesalii Bruxellensis..., suorum de humani corporis fabrica librorum epitome..., Basileae 1555.

${ }^{137}$ Ioannes Philoponus. Przypuszczalnie: Commentaria Ioannis Gramatici Alexandrei cognomento Philoponi in libros posteriorum Aristotelis..., Venetijs 1542.

${ }^{138}$ Franciscus Vicomercatus (Franceso Vimercati) (1474-1598), filozof, lekarz. Wiele wydań, przykładowo: Francisci Vicomercati Mediolanensis In octo libros Aristotelis De naturali auscultatione commentarii. Et eorundem librorum e Graeco in Latinum per eundem conversio..., Lutetiae Parisiorum 1550.

${ }^{139}$ Franciscus Vicomercatus. Francisci Vicomercati. In quatuor libros Aristotelis meteorologicorum Commentarii et eorundem librorum e Graeco in Latinum per eundem conversio, Venetiis 1565 lub wydanie paryskie z $1556 \mathrm{r}$. 
38 Francisci Robortelli in librum Ar[istote]lis de arte Poetica ${ }^{140}$

39 Politica Ar[istote $]$ lis ${ }^{141}$

40 Simplicii $\mathrm{Co}[\mathrm{m}]$ mentarii in libros $\operatorname{Ar}[$ istote $]$ lis de coelo ${ }^{142}$

41 Joannis Gra[m]matici in libros Ar[istote]lis de generatio[n]e et interitu Graece ${ }^{143}$

42 Alexandri Aphrodisiensis in priora $\operatorname{Ar}[$ istote $] l_{\text {lis }}{ }^{144}$

43 Themistii in posteriora Aristotelis ${ }^{145}$

44 Simplicii magni in Praedicam[en]ta Aristotelis ${ }^{146}$

45 Statuta antiqua Regni Poloniae ${ }^{147}$

46 Alexandri Aphrodisci quaestio[n]es naturales ${ }^{148}$

47 Opera Ar[istote]lis in uno volumine ${ }^{149}$

48 Aecius Medicus ${ }^{150}$

49 Alexandri Aphrodisci in Methaphisica $\operatorname{Ar}[$ istote $]$ lis ${ }^{151}$

50 Athonei Coenae sapient[ium] ${ }^{152}$

${ }^{140}$ Francesco Robortello (Francesco Robertèlli, Franciscus Robortellus) (1516-1567), humanista, filozof, filolog. Prawdopodobnie: Francisci Robortelli Vtinensis, In librum Aristotelis de arte poëtica, explications..., Basileae 1555.

${ }^{141}$ Wiele wydań, przykładowo: Aristotelis Stagiritae Politicorum siue de republica libri octo Leonardo Aretino interprete cum D. Thomae Aquinatis explanatione nunc denuo summa cura ad manuscriptum exemplar collata, atque compluribus in locis restituta..., Venetiis 1558.

${ }^{142}$ Simplicius. Prawdopodobnie: Simplicii Commentaria in quatuor libros De coelo Aristotelis. ..., Venetiis 1555.

${ }^{143}$ Ioannes Philoponus. Prawdopodobnie: Ioannis Grammatici Philoponi Alexandrei Commentaria in libros De generatione, et corruptione Aristotelis ex colloquiis Ammonii Hermae..., Venetiis 1549.

${ }^{144}$ Alexander Aphrodisiensis (Alexander Afrodiseus) (przełom II i III w.), grecki filozof, komentator Arystotelesa. Prawdopodobnie: Alexandri Aphrodisiensis In Priora resolutoria Aristotelis Stagiritae explanatio. ..., Venetiis 1549.

${ }^{145}$ Themistius (Themistios) (317 - ok. 390), grecki filozof i retor. Prawdopodobnie: Themistii Peripatetici lucidissimi, Paraphrasis in Aristotelis Posteriora, \& Physica, in libro item De Anima, Memoria et Reminiscentia, Somno et Vigilia, Insomniis, \& Divinatione per Somnium..., Venetiis 1560.

${ }^{146}$ Simplicius. Prawdopodobnie: Simplicii magni doctoris cognomento Commentationes accuratissimae in Praedicamenta Aristotelis..., Venetiis 1550.

${ }^{147}$ Dzieła nie udało się zidentyfikować. Być może: Statut Łaskiego, czyli dzieło Jana Łaskiego (1456-1531), prymasa Polski, kaclerza wielkiego koronnego, kodyfikatora prawa wydanego pod tytułem Commune incliti Polonie Regni priuilegium..., Cracouie 1506. Ale możliwym autorem jest także Jan Herburt z Fulsztyna (Joannes Herbortus de Fulstyn) (1508-1577), prawnik, historyk. Być może: Statuta regni Poloniae, in ordinem alphabeti digesta. A Ioanne Herborto de Fulstyn..., Cracovia 1567 . Zob. też poz. 184/85 i 184/102 oraz 202/8, 202/87 oraz 202/118.

${ }^{148}$ Alexander Aphrodisiensis. Prawdopodobnie: Alexandri Aphrodisiensis... Quaestiones naturales et morales, et de fato... De anima liber primus... De anima liber secundus, unà cum commentario de mistione..., Venetiis 1555.

${ }^{149}$ Dzieła nie udało się zidentyfikować.

${ }^{150}$ Aetius Amidenus (Aezio di Amida) (poł. V w. - poł. VI w.), grecki lekarz. Prawdopodobnie: Aetii medici Graeci Contractae ex ueteribus medicinae sermones XVI. Per Ianum Cornuarium..., Venetiis 1553.

${ }^{151}$ Alexander Aphrodisiensis. Dzieła nie udało się zidentyfikować.

${ }^{152}$ Athenaeus Naucratites (Athenaeus Epigrammaticus, Athenaeus Grammaticus, Athenaeus Sophistes) (II/III w.), grecki retor, gramatyk. Athenaei Dipnosophistarum siue Coenae sapientium libri 15... cum pluribus ex manuscriptis antiquissimis exemplaribus additis..., Lugduni 1556 lub bazylejskie wydanie z $1535 \mathrm{r}$. 
51 Petri Victorii in libros Ar[istote]lis de arte dicen[di] ${ }^{153}$

52 Simplicii Co[m]mentarii in Enchiridion Epictet ${ }^{154}$

53 Joannis Montani Consilia ${ }^{155}$

54 Galeni Graeci Primus et s[e]c[un]dus Thomus ${ }^{156}$

55 Opera Graeca Hypocratis ${ }^{157}$

56 Imagines vivae Corporis humani ${ }^{158}$

57 Andreae Matthaei Epistolar[um] medicinaliu[m] $]^{159}$

58 Mesuae opera medica ${ }^{160}$

59 Joa[n]nis Bapt[ist]ae in Dioscoridem a[n]nota[men] $\operatorname{ta}^{161}$

60 Dioscoridis opera ${ }^{162}$

61 Medici Antiqui om[ne]s in uno volumi[n] $\mathrm{o}^{163}$

62 Chirurgia Joannis de Vigo ${ }^{164}$

${ }^{153}$ Piero Vettori (Petrus Victorinus) (1499-1585), włoski pisarz, filolog, humanista. Prawdopodobnie: Petri Victorii Commentarii in tres libros Aristotelis De arte dicendi..., Florentiae 1548.

${ }^{154}$ Simplicius. Prawdopodobnie: Simplicii philosophi grauissimi Commentarius in Enchiridion Epicteti philosophi stoici, quo uniuersa hominum vita instituitur, \& libertatis recuperandae via monstratur, Venetiis 1569.

${ }^{155}$ Giovanni Battista de Monte (Johannes Baptista Montanus, Giovanni Battista Monti) (14981551), włoski lekarz, humanista. Prawdopodobnie: Ioannis Baptistae Montani Veronensis... Consilia Medica Omnia,... Partivm Operis Totivs Argvmenta. Prima est de morbis partium. Secunda est de febribus. Tertia continet Chirurgica..., Norimbergae 1559.

${ }^{156}$ Claudius Galenus. Dzieła nie udało się zindentyfikować.

${ }^{157}$ Hippocrates (Hippocrates Cos, Hippokrátes, Ippokrátis) (460-370 p.n.e.), grecki lekarz, ,ojciec medycyny". Przypuszczalnie: Apanta ta tou Ippokratous. Omnia opera Hippocratis, Venetiis 1526.

158 Juan Valverde (Juan Valverde de Amusco, Ioannes Valverdus) (1525-1588), lekarz. Prawdopodobnie: Vivae imagines partium corporis humani... De humani corporis fabrica librorum epitome, [Juan de Valverde], Antverpiae 1566.

${ }_{159}$ Pietro Andrea Mattioli (Petrus Andreas Matthiolus, Pierre André Matthiole) (1501-1577), włoski lekarz, botanik, nadworny medyk cesarza Maksymiliana II. Przypuszczalnie: Petri Andreae Matthioli Senensis Medici Epistolarum Medicinalium Libri Quinque, Lugduni 1564.

${ }^{160}$ Yuhanna ibn Masawaih (Ibn Masawaih, Mesue, Masuya) (ok. 777-857), arabski lekarz, thumacz greckich dzieł. Prawdopodobnie: Mesuae Graecorum, ac Arabum clarissimi medici Opera quae extant omnia..., Venetiis 1562.

${ }^{161}$ Giovanni Battista Cipelli (Joannes Baptista Aegnatius, Ioannes Baptista Egnatius) (1478-1553), włoski humanista, filolog, poeta. In Hoc Volvmine Haec Continentvr. Ioannis Baptistae Egnatii Veneti In Dioscoridem Ab Hermolao Barbaro Tralatvm Annotamenta. ... Pedacii Dioscoridis Anazarbei de Medicinali materia ab eodem Barbaro latinitate primum Donati Libri quinque..., Venetiis 1516.

${ }^{162}$ Dioscorides Pedanius (Dioscoride, Dioscorides Anazarbeus, Dioscorides Pedacius) (ok. 40-90), grecki lekarz, farmakolog, botanik. Dzieło niezidentyfikowane. Być może: Dioscoridis Anazarbei De medica materia libros quinque enarrationes eruditissimae doctoris Amati Lusitani medici ac philosophi celeberrimi, quibus non solum officinarum seplasiariis..., Venezia 1553 lub Pedacii Dioscoridae Anazarbensis De Materia Medica Libri V. Iano Cornario Medico Physico interprete. Eivsdem Iani Cornarii Emblemata, singulis capitibus adiecta. Dioscoridae De Bestiis Venenvm Eiacvlantibvs, Et Letalibus medicamentis Libri II..., Basileae 1557.

${ }^{163}$ Medici antiqui omnes, qui latinis literis diuersorum morborum genera \& remedia persecuti sunt, undique conquisiti, \& uno uolumine comprehensi..., Venetiis 1547.

${ }^{164}$ Giovanni De Vigo (Ioannes de Vigo, Jean de Vigo) (1450-1525), włoski lekarz, chirurg. Prawdopodobnie: Opera domini Io. de Vigo in chyrurgia excellentissimi. Additur chyrurgia Mariani sancti Barolitani Ioannis de Vigo discipuli. Que in nouem libris prime partispractice copiose dicte Io. de Vigo..., Lugduni 1538. 
63 Alexandri Traliani libri Graeci ${ }^{165}$

64 Aecius Graecus ${ }^{166}$

65 Paulus Acineta Graecus ${ }^{167}$

66 Serapio de Simplicibus ${ }^{168}$

67 Anthonii Fumanelli Maedicae Artis p[er]icia ${ }^{169}$

68 Opera Avicennae ${ }^{170}$

69 Ar[istote $]$ lis $\mathrm{S}[\mathrm{e}] \mathrm{c}[\mathrm{un}] \mathrm{d}[\mathrm{u}] \mathrm{m}$ volumen de Rhetorica ${ }^{171}$

70 Fasciculus Maedicinae ${ }^{172}$

71 Thadaei Florentini $\mathrm{Co}[\mathrm{m}]$ mentaria in Hipocrate $[\mathrm{m}]^{173}$

72 Othonis Historici ${ }^{174}$

72a Thadei in parva arte Galeni ${ }^{175}$

73 Opera Isaac ${ }^{176}$

74 Expositio Gentilis in Avicenna ${ }^{177}$

${ }^{165}$ Alexander Trallianus (Alexander Trallensis, Alessandro di Tralle) (ok. 525-605), bizantyjski lekarz. Wiele różnych wydań, być może: Alexandrou Trallianou iatrou Biblia duokaideka. Razē logos peri loimikēs apo tēs surōn dialektou exellēnistheis. Alexandri Tralliani medici lib. 12. Rhazae de pestilentia libellus ex Syrorum lingua in Graecam translatus. Iacobi Goupyli in eosdem castigationes. Ex bibliotheca regia, Lutetiae 1548.

${ }^{166}$ Aetius Amidenus. Dzieła nie udało się zidentyfikować.

${ }^{167}$ Paulus Aegineta (Paûlos ho Ai'ginetes, Paolo d'Egina) (625-690), bizantyjski lekarz. Dzieła nie udało się zidentyfikować.

${ }^{168}$ Serapion (Serapion Medicus, Serapion Maior, Ianus Damascenus, Ioannes Damascenus) (druga poł. IX w.), lekarz arabski. Prawdopodobnie: In hoc volumine continentur, insignium medicorum, Ioan. Serapionis Arabis De simplicibus medicinis opus praeclarum \& ingens. Auerrois Arabis, De eisdem opusculum perutile. Incerti item autoris De centaureo libellus hactenus Galeno inscriptus. ..., Argentorati 1531.

${ }^{169}$ Antonio Fumanelli (Antonio Fumanellus) (?-?), włoski lekarz. Antonii Fumanelli Veronensis, ..., Opera multa, \& varia, cum ad tuendam sanitatem, tum ad profligandos morbos plurimum conducentia. ..., Tiguri 1557.

170 Avicenna (Abu 'Ali al-Husain ibn 'Abd Allah ibn Sina, Avicenne, Awicenna) (980-1037), irański lekarz, filozof, komentator Arystotelesa. Prawdopodobnie: Avicenne perhypatetici philosophi ac medicorum facile primi Opera in lucem redacta ac nuper quantum ars niti potuit per canonicos emendata. Logyca. Sufficientia. De celo et mundo..., Venetijs 1508.

${ }^{171}$ Arystotelis (Aristotele, Aristoteles Stagirites) (384-322 p.n.e). Prawdopodobnie: Omnia quae extant opera. ... Secundum Volumen Aristotelis De Rhetorica, Et Poetica Libri, Cum Averrois In Eosdem Paraphrasibvs..., Venetiis 1562.

${ }^{172}$ Dzieła nie udało się zidentyfikować.

${ }^{173}$ Thaddaeus Alderottus (Taddeo Alderotti, Taddée de Florence) (ok. 1210-1295), włoski lekarz, jeden z pierwszych profesorów organizujących medyczną edukację na uniwersytetach. Być może: Thaddei Florentini Expositiones in arduum aphorismorum Ipocratis volumen. In diuinum pronosticorum Ipocratis librum. In preclarum regiminis acutorum Ipocratis opus. In subtilissimum Ioannitij Isagogarum libellum..., Venezia 1527.

${ }^{174} \mathrm{~W}$ rękopisie zapis sugeruje, że chodzi o jedno dzieło: Othonis Historici Thadei in parva arte Galeni. Prawdopodobnie chodzi o dwa dzieła: Othonis Historici, którego nie udało się zidentyfikować, zob. poz. 202/18) oraz Thadei in parva arte Galeni, zob. poz. 72a.

175 Thaddaeus Alderottus. Prawdopodobnie: Thaddei Florentini... In C. Gal. Micratechnen commentarij secunde editionis..., Neapoli 1522.

${ }^{176}$ Dzieła nie udało się zidentyfikować.

${ }^{177}$ Prawdopodobnie Gentile da Foligno (Gentilibus de Fulgineo, Gentilis Fulginas) (?-1348), włoski lekarz, Gentilis de febribus. Expositio subtilissimi interpretis Gentilis in prima fen quarti canonis Auicenne..., Venetijs 1526. 
75 Senecae Tragediae ${ }^{178}$

76 Luminare maius ${ }^{179}$

$77 \quad$ Auli Gelli noctes Atticae ${ }^{180}$

78 Theodori Suingleri in arte[m] medica[m] Galeni ${ }^{181}$

79 Andreae Fricii de Republica ${ }^{182}$

80 Practica Savanarollae de Febribus ${ }^{183}$

81 Novum testam[en]tu[m] Graecolatinum ${ }^{184}$

82 Mathiolus in Dioscoridem ${ }^{185}$

83 Calvini Comentaria in Isaiam ${ }^{186}$

84 Prophetia Isaiam Hebraice ${ }^{187}$

85 Statuta Regni ${ }^{188}$

86 Scriptores Chirurgici ${ }^{189}$

87 Herodotus Graecus ${ }^{190}$

\footnotetext{
${ }^{178}$ Lucius Annaeus Seneca (4 p.n.e. - 65 n.e.). Wiele wydań, przykładowo: Senecae Tragoediae, Florentiae 1513.

${ }^{179}$ Identyfikacja niepewna (kilku autorów wydało dzieła o tym tytule). Być może Nicollo Mutoni (Nicolaus Mutonus, Nicolao Mutoni) (XVI w.), włoski lekarz. Luminare Maius, Lumen Apothecariorum, et Aromatariorum Thesaurus omnibus cum Mecidis, tum aromatariis pernecessaria opera, in quibus multa clarissimorum Medicorum pharmaca, Nicolai Mvtoni Medici Mediolanensis..., Venetiis 1553.

${ }^{180}$ Aulus Gellius (ok. 130 - po 180), rzymski pisarz, gramatyk, miłośnik starożytności. Wiele wydań, przykładowo: Auli Gellii... Noctes Atticae, Lugduni 1555.

${ }^{181}$ Theodor Zwinger (Theodorus Zuinggerus, Theodor Speiser) (1533-1588), szwajcarski learz. In artem medicinalem Galeni, tabulae \& commentarij..., Basileae 1561.

${ }_{182}$ Andrzej Frycz Modrzewski (1503-1572). Prawdopodobnie: Andreae Fricii Modrevij De republica emendanda libri quinque, recogniti \& aucti: quorum Primus, De moribus. Secundus, De legibus. Tertius, De bello. Quartus, De ecclesia. Quintus, De schola..., Basileae 1559.

${ }^{183}$ Giovanni Michele Savonarola (Ioannes Michael Sauonarola, Savonarola) (1384-1468), włoski lekarz. Prawdopodobnie: Practica Sauonarolae de febribus canonica Michaelis Sauonarolae De febribus, De pulsibus, De vrinis, De egestionibus, De omnibus Italie balneis..., Venetiis 1543.

${ }^{184}$ Wiele wydań, przykładowo: Novum Testamentium graece et latine diligentia Des. Erasmi Roterod. emendatißimum, et iam postremo ad multa exemplaria, tam impressa quàm manuscripta, diligenter castigatum et editum..., Basileae 1558.

${ }^{185}$ Pietro Andrea Mattioli. Wiele wydań, przykładowo: Petri Andreae Matthioli medici Senensis Commentarii, in libros sex Pedacii Dioscoridis Anazarbei, de medica materia..., Venetijs 1554.

186 Jean Calvin (Johannes Calvin, Ioannes Calvinus) (1509-1564). Wiele wydań, przykładowo: Ioannis Calvini Commentarii in Isaiam prophetam..., Genevae 1570.

${ }_{187}$ Yesha yah Isaias Propheta: hebraice, graece et latine:addita est autem duplex latina interpretatio, Hieronymi \& Munsteri. Accesit \& succincta difficiliorum Hebraicorum vocabulorum expositio, collecta per Sebastianum Munsterum ex Davidis Kimhi commentario, Basileae 1542 lub wydanie z 1535 r. (także bazylejskie).

${ }^{188}$ Dzieła nie udało się zidentyfikować. Zob. poz. 184/45 i 184/102 oraz 202/8, 202/87 oraz 202/118.

${ }^{189}$ Prawdopodobnie: Chirurgia. De chirurgia scriptores optimi quique veteres et recentiores, plerique in Germania antehac non editi, nunc primum in vnum coniuncti volumen... per Andream Gessnerum F. et Iacobum Gessnerum fratres, Tiguri 1555.

${ }^{190}$ Herodot (Herodotos, Herodotus Halicarnasseus, Hérodote) (484-420 p.n.e.). Wiele wydań, przykładowo: Herodoto Halicarnaseo historico, Delle guerre de greci, et de persi. Tradotto..., Venetia 1565 .
} 
88 In libros Regum Petri Martiris Co[m]mentaria ${ }^{191}$

89 Anathomia Vesalii Latina ${ }^{192}$

90 Fasciculus reru[m] expetendar[um $]^{193}$

91 Jus Civile manusriptor[um] libror[um] ${ }^{194}$

92 Thucitides Graecus ${ }^{195}$

93 Petri Martiris in librum judicu[m] Co[m]me[n]taria ${ }^{196}$

94 Imagines Geographicae ${ }^{197}$

95 Chronica Polonica ${ }^{198}$

96 Chirurgia Guidonis ${ }^{199}$

97 Livius ${ }^{200}$

98 Dictionariu[m] Graecu[m] $]^{201}$

99 De morbo Gallico o[mn]ia op[e]ra $\mathrm{ra}^{202}$

100 Simpliciu[m] medicam[en]tor[um] Joannis Danci lib[er] no[n] ligat[us]

100a Tabulae Simpliciu[m] medicam[en]-tor[um] eiusd[em] no[n] ligatae ${ }^{203}$

${ }^{191}$ Petrus Martyr (Petrus Martyr Vermilius, Pietro Martire Vermiglii Fiorentino) (1499-1562), kalwiński teolog, humanista. Prawdopodobnie: In duos libros Samuelis prophetae qui vulgo priores libri regum appellantur d. Petri Martyris Vermilii Florentini..., Tiguri 1567.

${ }^{192}$ Andreas Vesalius. Prawdopodobnie jedno z wydań: De humani corporis fabrica libri VII (przykładowo Basileae 1555).

${ }^{193}$ Fasciculus rerum expetendarum ac fugiendarum. In quo primum continetur Concilium Basiliense: non illud, quod in magno conciliorum volumine vulgo circumfertur, sed quod Aeneas Syluius (qui postea Pius 2. est appellatus)..., Coloniae 1535.

${ }^{194}$ Nieznany rękopis.

${ }^{195}$ Dzieła nie udało się zidentyfikować.

${ }^{196}$ Petrus Martyr. Wiele wydań, przykładowo: In librum iudicum D. Petri Martyris Vermilii Florentini..., commentarii doctissimi, cum tractatione perutili rerum \& locorum..., Tiguri 1561.

${ }^{197}$ Dzieła nie udało się zidentyfikować. Prawdopodobnie: atlas factice (atlas sztuczny) powstały w wyniku oprawienia zbioru luźnych map.

${ }_{198}$ Maciej Miechowita (Mathiae de Mechovia, Maciej Karpiga) (1457-1523), lekarz, historyk, astrolog, profesor Uniwersytetu Krakowskiego. Mathiae de Mechovia, Chronica Polonorum, Cracoviae 1521 . Niewykluczone jednak, że pod tym tytułem kryje się jedno z wydań dzieła Marcina Kromera: De Origine Et Rebvs Gestis Polonorvm Libri XXX: Adiecta est in fine, eiusdem autoris funebris Oratio, Sigismvndi Regis uitam compendiose complexa (np. Basileae 1555) lub dzieło Jana Herburta Chronica, siue Historiae Polonicae compendiosa... descriptio: authore magnifico viro Ioanne Herburto de Fulstin..., Basileae 1571.

${ }^{199}$ Guido de Caliaco (Gui de Cauliac, Guido Cauliac, Guido Cauliacus) (1290-1386), francuski lekarz, chirurg. Prawdopodobnie: Chirurgia Guidonis de Cauliaco, addita recepta aquae balnei de porecta per egregium medicinae doctorem dominum Thuram de Castello Bonon..., Lugduni 1537.

${ }^{200}$ Titus Livius (59 p.n.e. -17 n.e.). Być może: Historiarum ab urbe condita decas tertia, Basel 1554.

${ }^{201}$ Wielu autorów i wydań. Być może chodzi o jedno z popularnych wydań: Dictionarium Graecum. Cyrilli collectio dictionum quae differunt significato. Dictiones latinae graecis expositae. Ammonii De similibus, \& differentibus dictionibus..., Venetiis 1525.

${ }^{202}$ Wielu autorów zajmowało się tym zagadnieniem. Być może chodzi o kilkukrotnie wznawiane dzieło sławnego padewskiego profesora medycyny Gabrielle Falloppio (1523-1562): Gabrielis Falloppii ... De morbo Gallico liber absolutissimus a Petro Agatho Materate, (eo legente) scriptus..., Patavii 1563.

${ }^{203}$ Poz. 100 i 100a to dwie części jednego nieoprawnego dzieła. Johannes Dantz (Joannes Danzius von Ast, Giovanni Danesio) (?-1546), włoski lekarz, botanik. Tabulae simplicium medicamentorum, quae apud Dioscoridem, Galenum et Plinio sunt, omnium... Quas aliae consequuntur tabulae... De 


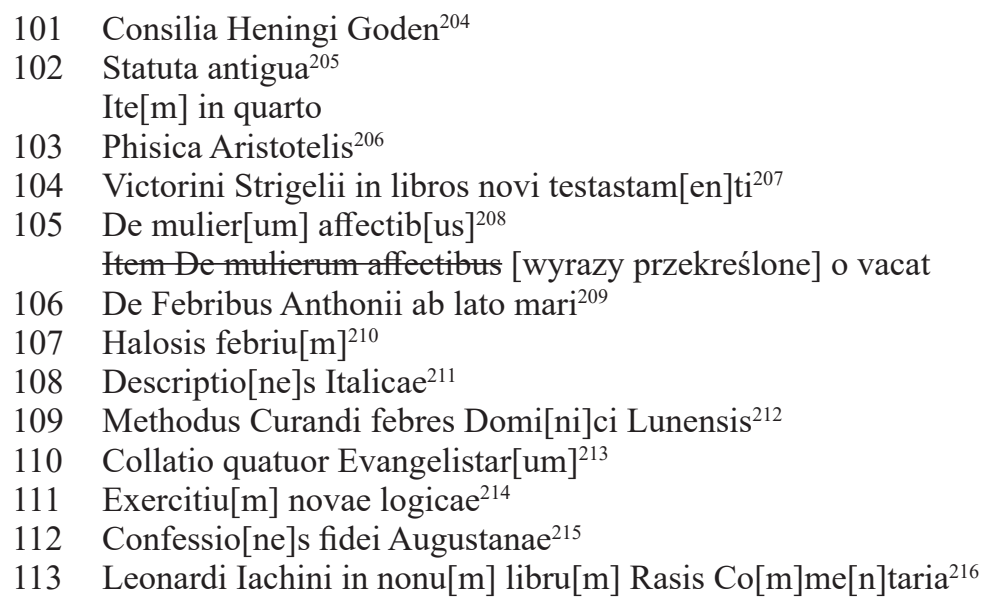

simplicium medicamentorum facultatibus in genere... dialogi quatuor... per Ioannem Dantzium..., Basileae 1543.

${ }^{204}$ Henning Gode (Henning Goden, Henningus Goden, Henning Godenus) (1450-1521), niemiecki prawnik. Wiele wydań, prawdopodobnie: Consilia ... D. Henningi Goden, Ordinarij in Iure Professoris in Academia Vitebergensi..., Budissinae 1563.

${ }^{205}$ Dzieła nie udało się zidentyfikować. Zob. też poz. 184/45 i 184/85 oraz 202/8, 202/87 oraz 202/118.

${ }^{206}$ Arystoteles. Wiele wydań, przykładowo: Physicorum Aristotelis, seu, De naturali auscultatione, libri octo..., Lugduni 1546.

${ }^{207}$ Victorinus Strigel (Victorianus Strigelius) (1524-1569), niemiecki teolog luterański. Prawdopodobnie: Hypomnemata in omnes libros Novi Testamenti quibus et genus sermonis explicatur et series concionum monstratur, \& nativa sententia testimoniis piae vetustatis confirmatur..., Lipsiae 1565.

${ }^{208}$ Przypuszczalnie: Gynaeciorum, hoc est de mulierum tum aliis tum gravidarum, parientium \& puerperarum affectibus \& morbis..., Basileae 1566.

${ }^{209}$ Dzieła nie udało się zidentyfikować.

${ }^{210}$ Jerome de Monteux (Hieronim Montuus, Mirebellus) (1495-1560), francuski lekarz. Halosis febrium quae omnium morborum grauissimae sunt libri IX. Chirurgica auxilia ad aliquot affectus, qui repentinam exigunt curationem. ... Authore Hieronymo Montuo Mirabelli..., Lugduni 1558.

${ }^{211}$ Dzieła nie udało się zidentyfikować.

${ }^{212}$ Domenico Leoni (Dominicus Leon, Domenico Leone) (1500-1599), włoski lekarz. Methodus curandi febres, tumoresque praeter naturam, ex Graecorum placitis deprompta..., Bononiae 1562.

${ }^{213}$ Prawdopodobnie: Collatio et unio quatuor evangelistarum domini nostri Jesu Christi: eorum serie et ordine, absque ulla confusione, permistione vel transpositione, seruato; cum exacta textus illibati recognitione, b.m.w. 1565.

${ }^{214}$ Identyfikacja niepewna. Być może Jan z Głogowa (Głogowczyk, Głogowita, Ioannes Glogoviensis, Glogar, Gloger) (ok. 1445-1507), polski astronom, matematyk, filozof, teolog. Exercicium nove logice seu librorum priorum et elenchorum magistri Joannis de Glogovia, Cracoviae 1511.

${ }^{215}$ Wiele wydań, przykładowo: Confessiones fidei Christianae tres, diuersis quidem_temporibus editae, sed cum uerae et catholicae ecclesiae sententia incorrupta congruentes, quarum prima exhibita est... Imp. Carolo V... in comicijs augustae, anno 30. Reliquae duae oblatae sunt synodo Tridentinae..., Francoforti 1559.

${ }^{216}$ Lionardo Giacchini (Leonardus Giachinus, Leonardus Iacchinus) (15??-15??), humanista, lekarz. Leonardi Iacchini Emporiensis... In nonum librum Rasis Arabis medici ad Almansorem regem, de partium morbis eruditissima commentaria ..., Basileae 1564. 
114 De admirandis Vngariae aquis ${ }^{217}$

115 Andreae Fricii de $\mathrm{p}[\mathrm{e}] \mathrm{c}[\mathrm{ca}]$ to originali libri $3^{218}$

116 Cathonis de re Rustica libri ${ }^{219}$

117 Historiae Italicae 220

118 Pindarus Graecus ${ }^{221}$

119 Joa[n]nis Calvini de vitandis sup[er]stitionib[us] $]^{222}$

120 Stancarus de Trinitate ${ }^{223}$

121 Fracastorii o[mn]ia opera ${ }^{224}$

122 Historia Italica Francisci Vicordini Italici ${ }^{225}$

123 Tabulae Astronomicae Joannis MontoRegii 226

124 Almanach Petri Pitati227

125 Martini Lutheri de Captivitate Babilonica 228

126 Aristotelis de Natura Joachimi Perionii 229

${ }^{217}$ Prawdopodobnie: De Admirandis Hvngariae Aqvis Hypomnemation... Fisci in Austria Praefectum, Vienna Avstriae 1551.

${ }^{218}$ Andrzej Frycz Modrzewski, Andreae Fricii Modrevii Libri Tres: Qvorvm Primvs, de Peccato originis. Secvndvs, de Libero hominis arbitrio. Tertivs, de Prouidentia \& Praedestinatione Dei aeterna. Eivsdem, De Mediatore, Libri II..., [Basileae] 1562.

${ }^{219}$ Wiele wydań, przykładowo: Libri de re rustica. M. Catonis lib. I M. Terentij Varronis lib. III L. Iunij Moderati Columellae lib. XII Eiusdem de arboribus liber separatus ab alijs. ...Palladium..., Venetiis 1533.

${ }^{220}$ Dzieła nie udało się zidentyfikować.

${ }^{221}$ Pindaros (Pindarus, Pindaro, Pindar) (ok. 518-438 p.n.e.), grecki poeta. Wiele wydań, przykładowo: Pindarou Olympia kai Pythia. Pindari Olympia et Pythia, Parisiis 1535.

${ }^{222}$ Jean Calvin. Wiele wydań, przykładowo: De vitandis superstitionibus, quae cum sincera fidei confessione pugnant, libellus Joannis Calvini..., Genevae 1550.

${ }^{223}$ Francesco Stancaro (Franciszek Stankar, Franciscus Stancarius) (1501-1574), początkowo teolog katolicki, później reformacyjny, hebraista, działał w Polsce. Franciscus Stancarus Mantuanus De Trinitate \& Mediatore Domino nostro Iesu Christo, aduersus Henricum Bullingerum, Petrum Petrum Martyrem, \& Ioannem Clauinum, \& reliquos Tigurinae ac Geneuensis ecclesiae Ministros, ecclesiae Dei perturbatores, [Cracoviae] 1562.

${ }^{224}$ Girolamo Fracastoro (Hieronymus Fracastorius, Jérome Fracastor) (ok. 1476/8-1553), włoski lekarz, filozof. Hieronymi Fracastorii Veronensis Opera Omnia: in vnum proximè post illius mortem collecta..., Venetiis 1555.

${ }^{225}$ Przypuszczalnie Francisco Guicciardini (Frances Guicciardin, Francesco Gvicciardini) (14831540), włoski pisarz, polityk, historyk. Wiele wydań, prawdopodobnie: L' Historia d' Italia, di M. Francesco Gvicciardini Gentil Hvomo Fiorentino..., Firenze 1561.

${ }^{226}$ Joannes de Monte Regio (Johannes Müller, Johannes Molitoris de Künigsperg, Johannes Germanus, Johannes Francus, Johannes Regiomontanus) (1436-1476), niemiecki astrolog, astronom, matematyk. Tabulae astronomicae, quas uulgo, quia omni difficultate \& obscuritate carent, resoluta vocant. ...Ratio, siue Apodeixis duodecim domorum coeli, authore Ioanne de Monteregio..., Norimbergae 1536 .

${ }^{227}$ Pietro Pitati (Petrus Pitatus, Petrus Pitatus Veronensis), włoski matematyk, astronom. Wiele wydań, przykładowo: Almanach nouum Petri Pitati Veronensis mathematici. Ad annos vndecim incipiens ab anno Christi 1552. vsque ad annum 1562. Isagogica in celestem astronomicam disciplinam. Tractatus tres..., Venetiis 1552.

${ }^{228}$ Martin Luther (1483-1546). Wiele wydań, przykładowo: De captivitate Babylonica ecclesaie, praeludium Martini Lutheri, Vuittemberae 1520.

${ }^{229}$ Joachim Périon (Joachimus Perionius, Gioachino Perionio) (1499-1559), francuski humanista, filolog. Wiele wydań, przykładowo: Aristotelis de natura, aut de rerum principiis libri 8..., Parisiis 1564. 
127 Eiusde[m] in libros $\operatorname{Ar}\left[\right.$ istote]lis de moribus ${ }^{230}$

128 Logica Aristotelis ${ }^{231}$

129 Joannis Rivii de admirabili Dei Co[n] $\operatorname{silio}^{232}$

130 Boccatius italice ${ }^{233}$

131 Nicolai Biesii Medicinae Theorica ${ }^{234}$

132 Introductoriu[m] Joannis de Sacro Busto ${ }^{235}$

133 Heliani de militaribus ordi[ni]b[us] institute[n]dis ${ }^{236}$

134 Georgii Trapesunci Rhetoricorum libri ${ }^{237}$

135 Regimen militem Polonice ${ }^{238}$

136 Odeporicu[m] itineris Constantinopolitani 239

137 Hipocratis Cornarii omnia opera [...] Cornarii ${ }^{240}$

138 In Dioscoridis libros Amati Lusitanii medici ${ }^{241}$

139 De stirpibus Melchioris Guilandini ${ }^{242}$

230 Prawdopodobnie: Ioachimi Perionii Cormoeriaceni De optimo genere interpretandi, in Aristotelis 10. libros ethicorum, siue de moribus, a se latinitate donatos, commentarij: In quibus et de optima imitandi ratione..., Basileae 1540.

${ }^{231}$ Wiele wydań, przykładowo: Logica Aristotelis ex tertia recognitione Libri Logicorum ad archetypos recogniti..., Parisiis 1543.

${ }^{232}$ Johann Rivius (Ioanne Rivio Atthendoriense) (1500-1553), niemiecki teolog i filolog. De admirabili Dei consilio in celando mysterio redemptionis humanae libri III, Basileae 1545.

${ }^{233}$ Giovanni Boccaccio (1313-1375). Dzieła nie udało się zidentyfikować.

${ }^{234}$ Nicolaus Biesius (Nicolaus Biese, Nicolaus Biesius Gandavensis) (1516-1572), lekarz, filozof. Nicolai Biesii Gandauensis Theoreticae medicinae lib. sex..., Antverpiae 1558.

235 Johannes de Sacrobosco (Joannes de Sacro Bosco, Joannes de Sacrobusto, Johann von Sacrobosco, Johannes Anglus) (ok. 1195-1256), matematyk, astronom. Jan z Głogowa. Introductorium compendiosum in tractatum sphere materialis magni Joannis de Sacrobusto qui abbreuiauit ex almagestis sapientis Ptholomei Claudij... et magistrum Joannem Glogoviensem..., Cracovie 1506 lub wydanie z $1513 \mathrm{r}$.

236 Aelianus Tacticus (II w.), grecki pisarz. Aeliani De militaribus ordinibus instituendis more graecorum liber..., Venetiis 1552 lub inne weneckie wydanie także z 1552 r. Ailianou Peri stratēgikōn taxē̄n hellēnikōn. Aeliani De militaribus ordinibus instituendis more graecorum liber...

${ }^{237}$ Georgios Trapezuntios (Georgius Trapezuntius, Georg von Trebizond) (1395-1484), bizantyński humanista, teolog, filolog. G. Trapezuntij Rhetoricorum libri quinque..., Parisiis 1538.

${ }^{238}$ Dzieła nie udało się zidentyfikować.

239 Pal Rubigál (Paulus Rubigallus Pannonius, Pavol Rubigal, Pal Rubigally) (1520-1577), węgierski humanista, ewangelicki teolog. Hodoeporicon Itineris Constantinopolitani, Avtore P. Rvbigallo Pannonio..., Wittembergae 1544.

${ }^{240}$ Hippocrates. Wiele wydań, przykładowo: Hippocratis coi medicorum omnium longe principis, opera quae ad nos extant omnia, per Ianum Cornarium medicum physicum latina lingua conscripta..., Basileae 1558.

${ }^{241}$ Joao Rodrigues de Castello Branco (Giovanni Roderico de Castelbarco, używał pseudonimu Amathus Lusitanus, Amato Lusitano, Amatus) (1511-1568), żydowski lekarz, botanik. Wiele wydań, przykładowo: In Dioscoridis Anazabei de medica materia libros quinque, Amati Lusitani doctoris medici ac philosophi celeberrimi enarrationes eruditissimae..., Lugduni 1558.

${ }^{242}$ Melchiorre Guilandino (Melchior Guilandinus, Melchior Wieland) (ok. 1520-1589), lekarz, botanik, podróżnik z Królewca. De stirpibus aliquot, epistolae 5. Melchioris Guilandini Borussi R. 4. Conradi Gesneri Tigurini 1. Eiusdem Guilandini ad illustrem comitem Nicolaum a Salmo \& c. Manuco diatae, hoc est auicuae Dei description..., Patavii 1558. 
140 Actuarii opera ${ }^{243}$

141 Julii Delphini in tertiu[m] libru[m] Galeni ${ }^{244}$

142 De genere Arati in pargameno ${ }^{245}$

143 Praxis reru[m] civiliu[m] Jodoci Damchuderiii 246

144 Joannis Vierii medicar[um] observationu[m] liber non ligatus ${ }^{247}$

145 Jacobi Lanterii, de modo substruendi terrena munimenta ad Urbes, no[n] ligatus ${ }^{248}$

146 Propositio[ne]s Theologicae ${ }^{249}$

147 Ordo iuris Bartholomei Groiczki ${ }^{250}$

148 Brevis narratio vitae Phillippi Mela[n] chtonis $^{251}$

149 Actuarii methodi medendi ${ }^{252}$

150 Libellus de Epidemia Loniceni ${ }^{253}$

151 Quaestio de flenbothomiis fiendis in omni dolore ${ }^{254}$

152 Rota martÿru[m] $]^{255}$

${ }^{243}$ Joannes Actuarius (Actuarius, Attuario, Ioannes Zacharias Actuarius) (1275-1330), bizantyński lekarz. Prawdopodobnie: Actuarii Ioannis filij Zachariae Opera. De actionibus et spiritus animalis affectibus, eiusque nutritione Lib. 2. De vrinis Lib. 7. Methodi medendi Lib. 6. ..., Parisiis 1556.

${ }^{244}$ Gulio Delfino (Iulius Delphinus) (?-1564), włoski lekarz. Iulii Delphini... In 3. Galeni artis medicinalis lib. explanatio. Eiusdem De ratione medicamentorum praescribendorum liber..., Venetiis 1557.

${ }^{245}$ Dzieła nie udało się zidentyfikować. Przypuszczalnym autorem może być Aratus (Aratus Solensis, Aratus Astronomus, Aratos Cilicien) (ok. 320-240 p.n.e.), grecki poeta.

${ }^{246}$ Joost de Damhouder (Jodocus Damhouder, Jodocus Damhouderius) (1507-1581), flandryjski prawnik. Wiele wydań, przykładowo: Praxis rerum civilium praetoribus, propraetoribus, consulibus, proconsulibus, magistratibus, reliquisque id genus iustitiariis ac officiarii..., Antverpiae 1567.

${ }^{247}$ Johannes Weyer (Joannes Wier, Ioannes Wierus, Piscinarius) (1515-1588) niderlandzko-niemiecki lekarz, demonolog. Ioannis Wieri Medicarvm observationvm rararum Liber I.: de Scorbuto, de Quartana, de Pestilentiali angina, Pleuritide Peripneumonia. De Hydropis curatione. De Curatione meatuum naturalium clausorum, \& quibusdam alijs..., Basileae 1567.

${ }^{248}$ Giacomo Lanteri (Jacomo de Lanteri, Jacobus Lanteriius) (15??-1560), włoski matematyk, inżynier. Iacobi Lanterii Brixiensis Libri duo, de modo substruendi terrena munimenta ad urbes, atque oppida, ceteraque loca omnia, quibus aditus hosti praecludatur..., Venetiis 1563.

${ }^{249}$ Wielu autorów i wiele wydań. Przykładowo: Propositiones Theologicae De Lege Et Euangelio, in quibus summa \& ordo Theologiae proponitur, Witebergae 1550 lub Propositiones theologicae repetentes summam doctrinae de iustificatione et bonis operibus, de quibus Deo iuvante publice disputabit in..., Witebergae 1570.

${ }^{250}$ Bartłomiej Groicki (ok. 1519/1534-1605), autor rozpraw prawniczych. Być może jedno z licznych wydań dzieła: Porządek Sadow y Spraw Mieyskich Prawa Maydeburskiego (np. Kraków 1559).

${ }^{251}$ Philip Melanchthon (Philipp Schwartzerdt, Philippi Melanchnecnon, Philippus Melanchthonius) (1497-1560), humanista, teolog, reformator religijny. Brevis Narratio Exponens Qvo Fine Vitam in Terris Svam Clavserit Reverendvs Vir D. Philippvs Melanthon..., [Vittebergae] 1560.

${ }^{252}$ Joannes Actuarius. Actuarii Ioannis filii Zachariae, Methodi medendi libri sex, quibus omnia, quae ad medicinam factitandam pertinent, fere complectitur..., Venetiis 1554.

${ }^{253}$ Niccolo Leoniceno (Nicolaus Leonibus, Nicolo da Lonigo, Nicolaus Leonicenus) (1428-1524), włoski lekarz, humanista. Libellus de epidemia quam uulgo morbum Gallicum uocant, [Nicolai Leoniceni uincentini], Venetiis 1497.

${ }^{254}$ Ludovico Paniza (Ludovicus Panizza Mantuanus, Lodovico Panizza) (XVI w.), włoski lekarz. Questio de phlobotomiis fiendis in omni dolore in omnique apostemate, praesertim in pleuresi ab excellentissimo doctore Lodouico Paniza physico Mantuano, Venetiis 1532.

${ }^{255}$ Dzieła nie udało się zidentyfikować. 
153 Vitae principum Turcar[um] Italice ${ }^{256}$

154 Gabrielis Phalopii Mutine[n] sis de ulcerib[us] $]^{257}$

155 Sebastiani Paparellae in librum Hippocratis de natura humana comme[n]tarii 258 Ite[m] In Octavo

156 Gramatica Graeca Cleonardi ${ }^{259}$

157 Athanasi Dialogi quinq[ue] de s. Trinitate Graeco Latini ${ }^{260}$

158 Rosariu[m] Scholae Trocedoffii ${ }^{261}$

159 Joa[n]nis Calvini in Ezechiele $[\mathrm{m}]^{262}$

160 Henrici Agrippae de occulta $\mathrm{Ph}\left[\right.$ ilosoph] $\mathrm{ia}^{263}$

161 Historiae Ecclesiasticae Eusebii pars p[ri]ma Item eiusdem pars s[e]c[un]da Item eiusdem pars Tertia [wyrazy pokreślone, poprawiane] ${ }^{264}$

162 Joannis Manardi Epistolar[um] medicinalium Libri 20 in uno volumine ${ }^{265}$

163 Joannis Manlii locoru[m] co[m]muniu[m] collectanea ${ }^{266}$

${ }^{256}$ Dzieła nie udało się zidentyfikować.

${ }^{257}$ Gabrielle Falloppio. Gabrielis Faloppii Mutinensis..., Libelli duo. Alter de ulceribus, alter de tumoribus praeter naturam..., Venetijs 1563 (lub II wydanie z 1566 r.).

${ }^{258}$ Sebastiano Paparella (Sebastiano Augeni, Sebastianus Paparella a Monte Santo) (1527-1603), włoski lekarz, filozof. Sebastiani Paparellae e Monte Sancto medici et philosophi In Hippocratis librum De natura humana commentarii duo..., Venetijs 1551.

${ }^{259}$ Nicolaus Clenardus (Nicolas Cleynaerts, Clenard) (1495-1542), autor wielokrotnie wznawianych prac do nauki języka hebrajskiego i greckiego. Przykładowo: Institutiones absolutissimae in linguam Graecam per Nicolam Clenardum..., Venetiis 1543.

${ }^{260}$ Św. Atanazy (Ảthanásios ho Mégas saint, Atanasio saint, Athanasius Alexandrinus saint) (295-373), biskup, teolog. Athanasiu Dialogoi 5, peri tēs hagias Triados = Athanasii Dialogi V, de sancta Trinitate, ... Anastasiu Kai Kyrillu ekthesis syntomos tēs orthodoxu pisteōs..., [Genevae] 1570 .

${ }^{261}$ Valentin Trozendorf (Valentin Trotzendorf, Valentin Friedland Trotzendorf, Valentinus Trocedorfius) (1490-1556), śląski pedagog, teolog protestancki. Rosarivm Schoae Trocedorfij, Contextvm Ex Rosis Decerptis ex Paradiso Domini: Adivncae Sunt Paecipvarvm sententiarum enarrationes ex ore Trocedorfij excepae, \& passim collectae studio Marci Rvlli..., Witebergae 1565 (lub wydanie z 1567 lub 1568 r.).

${ }^{262}$ Jean Calvin. Identyfikacja niepewna: Leçons ou Commentaires et expositions de M. Jean Calvin, sur les vingt premiers chapitres des revelations du prophete Ezechiel, Geneve 1565.

${ }^{263}$ Henricus Cornelius Agrippa ab Nettesheym (Henricus Cornelius Agrippa) (1486-1535), niemiecki humanista, okultysta, astrolog, alchemik, teolog, filozof. Wiele wydań, przykładowo: Henrici Cor. Agrippae ab Nettesheym De occulta philosophia libri 3. Quibus accesserunt, spurius Agrippae liber de ceremonijs magicis. Heptameron Petri de Albano..., Parisiis 1567.

${ }^{264}$ Eusebius Caesariensis. Identyfikacja niepewna, być może: Historiae Ecclesiasticae Pars...: 1: Historiae ecclesiasticae pars prima, qva continentur Eusebij cognomento Pamphili Caesareae Palaestinae Episcopi lib. 10. Eiusdem de vita Constantini magni lib. 4. Oratio Constantini magni ad sanctorū coetū. Oratio eiusdem Eusebij in laudem Constantini magni..., Lovanii 1569.

${ }^{265}$ Giovanni Manardi (Ioannes Manardus) (1462-1536), włoski lekarz, astrolog, botanik. Wiele wydań, przykładowo: Ioannis Manardi Medici Ferrariensis... Epistolarvm medicinalium libri viginti, denuò nunc... collatt \& editi: Ejusdem in Joan. Mesue Medicamenta Simplicia \& Composita annotationes \& censurae..., Basileae 1549.

${ }^{266}$ Johannes Manlius (Janž Mandelc, Johannes Manlyus, Hans Mannel) (?-1605), drukarz, prawdopodobnie słoweńskiego pochodzenia. Wiele wydań, przykładowo: Locorum communium collectanea a Ioanne Manlio per multos annos, tum ex lectionibus D. Philippi Melanchthonis, tum ex aliorum doctissimorum vinorum relationibus excerpta..., Francofurti ad Moenum 1568. 
164 De fossilibus Gesneri ${ }^{267}$

165 Budei de Asse ${ }^{268}$

166 Galeni in libru[m] Hipocratis de humorib[us] Co[m]mentarii 269

167 Dioscoridis de Curationib[us] morbor[um] ${ }^{270}$

168 Opera Ciceronis in octo libr[is] ligata rubro Corrigio involuta ${ }^{271}$

169 Psalteriu[m] $]^{272}$

170 Plinii Historici tres partes ${ }^{273}$

171 Discursi Nicolai Machabei in Livu[m] Italice ${ }^{274}$

172 Historiae Machabelli Italice ${ }^{275}$

173 Petri Vireti, de co[m]municatio[n]e fideliu[m] $]^{276}$

174 Ars Magica Jodoci Vilichi277

175 Aulus Gellius ${ }^{278}$

176 Quintilianus ${ }^{279}$

177 Historiae $\operatorname{Ar}[$ istote $] l_{1}$ s $^{280}$

178 Lactantius $^{281}$

${ }^{267}$ Conrad Gesner. De omni rerum fossilium genere, gemmis, lapidibus, metallis, et huiusmodi, libri aliquot, ..., Opera Conradi Gesneri..., Tiguri 1565/1566.

${ }^{268}$ Guillaume Bude (Guilielmus Budaeus) (1467-1540), francuski humanista. Wiele wydań, przykładowo: De asse et partibus eius libri quinque Gulielmi Budei ..., Parigi 1524.

${ }^{269}$ Claudius Galenus. Galeni In Hippocratis Librum De humoribus, commentarij tres: Eiusdem reliquum sexti commentrarij in sextum de vulgaribus morbis: itemque septimus, \& octaus: nuper in lucem editi, ac latinitate donati: Io Baptista Rasario interprete, Venetiis 1562.

${ }^{270}$ Dioscorides Pedanius. Euporista Ped. Dioscoridis Anazarbei ad Andromachum, hoc est De curationibus morborum per medicamenta paratu facilia, libri 2..., Argentorati 1565.

${ }^{271}$ Marcus Tulius Cicero (106-43 p.n.e.). Dzieła nie udało się zidentyfikować.

${ }^{272}$ Dzieła nie udało się zidentyfikować.

${ }^{273}$ Gaius Plinius Secundus (Maior) (23-79). Dzieła nie udało się zidentyfikować, wiele różnych wydań.

${ }^{274}$ Niccolò di Bernardo dei Machiavelli (Nicolaus Machiavellus) (1469-1527). Wiele wydań, przykładowo: Discorsi di Nicolo Machiauelli, fiorentino, sopra la prima deca di Tito Livio, diuisi in tre libri..., In Vinegia 1537.

${ }^{275}$ Niccolò di Bernardo dei Machiavelli. Wiele wydań, przykładowo: Historie di Nicolo Machiauelli, cittadino, et secretario fiorentino..., In Vinegia 1554.

${ }^{276}$ Pierre Viret (Pietro Vireto, Petrus Viretus) (1511-1571), szwajcarski teolog. Petri Vireti De communicatione fidelium, quibus cognita est veritas Euangelii, cum Papistarum ceremoniis, ac praesertim cum baptismo, nuptiis, missa, funeribus \& exequiis, libellus apprimè vtilis, Geneuae 1551.

${ }^{277}$ Jodocus Willichius (Iodocus Vuillichius, Iodoc Vuillich, Josse Willich) (1501-1552), niemiecki lekarz, filolog, humanista. Ars magirica hoc est, coquinaria, de cibariis, ferculis opsonijs, alimentis \& potibus diuersis parandis, eorumque facultatibus..., Tiguri 1563.

${ }^{278}$ Aulus Gellius. Prawdopodobnie błąd spisujących lub drugi egzemplarz tego samego dzieła. W inwentarzu z rkps 202 Aulus Gellius występuje tylko raz. Zob. poz. 202/279.

${ }^{279}$ Marcus Fabius Quintilianus (Quinctilian) (ok. 35-95), rzymski retor, pedagog. Wiele wydań, przykładowo M. Fabij Quintiliani... Oratoriarum institutionum libri 12. Doctissimorum uirorum, Ioachimi Camerarij, Ioannis Sichardi, aliorumque opera..., Colonia Agrippinae 1555.

${ }^{280}$ Dzieła nie udało się zidentyfikować. Prawdopodobnie: Aristotelis et Theophrasti Historiae, cum de natura animalium, tum de plantis et earum causi..., Lugduni 1552. Zob. poz. 202/205.

${ }^{281}$ Lucius Coelius Lactantius Firmianus (Lactantius, Lucius Caecilius Firmianus) (ok. 250-320), chrześcijański pisarz, filozof. Wiele wydań, przykładowo: L. Coelii Lactantii Firmiani Diuinarum institutionum lib. 7. De ira Dei liber 1. De Opificio Dei liber 1. Epitome in libros suos, liber acephalos. Carmen de phoenice. Resurrectione dominica. Passione Domini..., Lugduni 1553. 


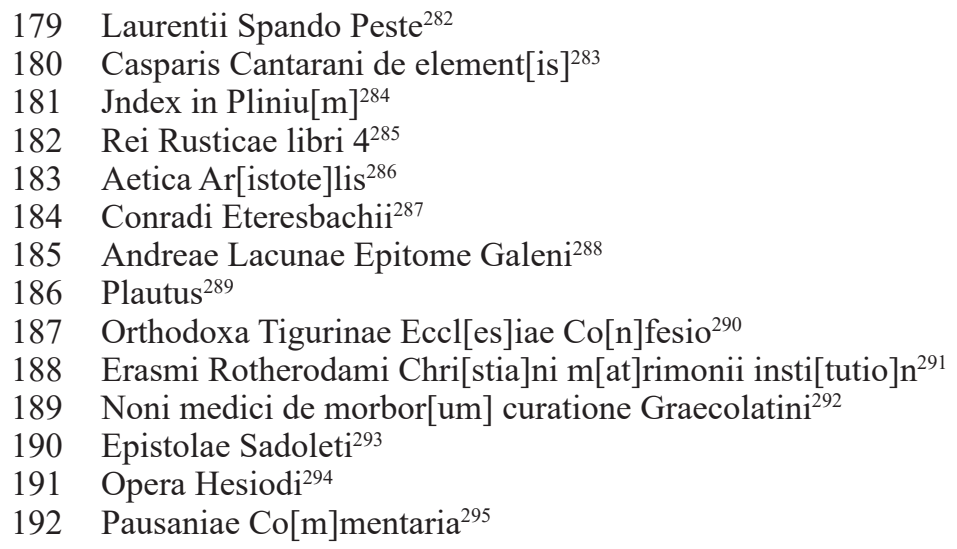

${ }^{282}$ Vavřinec Špán (Vavřinec Spano, Laurentius Span a Spanow, Laurenz Span von Spanow) (1530-1575), czeski lekarz, poeta. Lavrentii Span A Sspanovv Doctoris Medici De Peste Libri Dvo..., Olomuncii [1561].

${ }^{283}$ Gasparo Contarini (Gasparus Contarenus, Casparo Contarenus) (1483-1542), wenecki dyplomata, kardynał, filozof, teolog. Gasparis Contareni Cardinalis ampliss. philosophi sua aetate praestantissimi De elementis \& eorum mixtionibus libri quinque..., Lutetiae Parisorum 1548 lub Gasparis Contareni... De elementis \& eorum mixtionibus libri quinque..., Parisiis 1564.

${ }^{284}$ Dzieła nie udało się zidentyfikować.

${ }^{285}$ Conrad Heresbach (Conradus Heresbachius, Konrad Heresbach) (1496-1576), niemiecki humanista, filolog, polityk. Rei rusticae libri quatuor, universam rusticam disciplinam complectens, una cum appendice oraculorum rusticorum Coronidis vice adiecta... auctore d.d. Conrado Heresbachio..., Coloniae 1570 lub wydanie z $1571 \mathrm{r}$.

${ }^{286}$ Dzieła nie udało się zidentyfikować. Wiele wydań w interperatacjach różnych autorów.

${ }^{287}$ Conrad Heresbach. Dzieła nie udało się zidentyfikować.

${ }^{288}$ Andrés de Laguna (Andrea Lacuna, Andreas Lacuna Secobiensis) (1499-1560), hiszpański lekarz, humanista. Wiele wydań, prawdopodobnie: Epitome Galeni Pergameni operum, in quatuor partes digesta, pulcherrima methodo vniuersam illius uiri doctrinam complectens: per And. Lacunam..., Basileae 1551.

${ }^{289}$ Titus Maccius Plautus (Plautus, Plauti, Plaut) (ok. 250-184 p.n.e.), rzymski komediopisarz. Prawdopodobnie: M. Acci Plauti Sarsinatis comici festiuissimi Comediae 20 diligentiss. a mendis repurgatae, et ..., Basileae 1535. Zob. poz. 202/313.

290 Orthodoxa Tigurinae Ecclesiae ministrorum Confessio illorum et fidem et doctrinam quam cum Catholica sanctorũ ecclesia com munem habent, continens, in primis autem de coena domini nostri Jesu Christi unà cum..., Tiguri 1545.

${ }^{291}$ Erasmus Rotterdamus. Prawdopodobnie: Christiani matrimonii institutio, per Des. Erasmum Roterodamum, opus nunc primum \& natum, \& excusum, Basileae 1526.

${ }^{292}$ Théophane Nonnos (Theophanes Nonnus, Theophanēs Chrysobalantēs) (X w.), bizantyński lekarz. Noni Medici Clarissimi De omnivm Particvlarivm Morborvm Cvratione, sic ut Febres quoque [et] Tumores praeter naturam complectatur..., Argentorati 1568.

${ }^{293}$ Jacopo Sadoleto (Jacob Sadolet, Jacobus Sadoletus) (1477-1547), włoski humanista, biskup Carpentras, kardynał. Prawdopodobnie: Epistolae De Dissidiis Religionis. Iacobi Sadoleti cardinalis, Iacobi Omphalii assessoris Imperatorij, Ioannis Sturmij, Argentorati 1539.

${ }^{294}$ Hesiodus (Hesiodos, Hésiode, Hesiod) (VIII/VII w. p.n.e.), grecki poeta. Wiele wydań, przykładowo: Hēsiodou erga kai hēmerai = Hesiodi opera \& dies..., Basileae 1559.

${ }^{295}$ Pausanias (Pausanías ho Periēgētés, Pausanias Periegetes, Pausania) (115-180), grecki pisarz, geograf. Prawdopodobnie: Pausaniae De florentiss. veteris Graeciae regionibus commentarii a Romulo Amasaeo... summa fide ac diligentia, conuersi..., Basileae 1557. 
193 Laurentius Valla ${ }^{296}$

194 Ethica Ar[istote]lis Graece ${ }^{297}$

195 Aesopi vita et fabollae ${ }^{298}$

196 Seneca Tragedia ${ }^{299}$

197 Isocratis or[ati]o[ne]s graece ${ }^{300}$

198 De $\mathrm{p}[\mathrm{ro}] \mathrm{nu}[\mathrm{n}]$ ciatione Latini et Graecis s[er]monis ${ }^{301}$

199 Consiliatio[ne]s locor[um] Scripturae Andreae Altameri ${ }^{302}$

200 Theoricae Planetar[um] Georgii Burbachii ${ }^{303}$

201 Constantini Caesaris de Agricultura ${ }^{304}$

202 Loci co[m]munes Phillippi Melanctonis ${ }^{305}$

203 Joannis Ludovici de disciplinis ${ }^{306}$

204 Ar[istote]lis de arte Rhetorica libri 3 Graece $^{307}$

205 Marci Heremitae de lege sp[i]ri[tu]ali Graece ${ }^{308}$

\footnotetext{
${ }^{296}$ Lorenzo Valla (Lorenzo della Valle, Laurentius Vallensis) (1406-1457), włoski humanista, filolog i filozof.

${ }^{297}$ Wiele wydań, przykładowo: Aristotelous Ëthikōn Nikomacheiōn biblia deka. Aristotelis De moribus ad Nicomachum, lib. 10, Parisiis 1555.

${ }^{298}$ Aesopus (Aesop, Aísōpos) (ok. 620-560 p.n.e.), grecki bajkopisarz. Prawdopodobnie: Historia vitae fortunaeque Aesopi, cum fabulis illius pluribus quingentis, et aliis quibusdam narrationibus..., Lipsiae 1544.

${ }^{299}$ Seneca. Zob. poz. 202/174. Wiele wydań, przykładowo: Lutii Annei Senece Cordubensis tres
} selectiores tragoediae in hoc volumine continentur. Hercules furens. Thyestes Meyeneus. Octania Romana..., Nurbergae 1520.

${ }^{300}$ Isocrates (Isocratus, Isocratous) (436-338 p.n.e.), grecki mówca, twórca teorii klasycznej prozy attyckiej. Wiele wydań, przykładowo: Isokratous Logoi apantes, kai Epistolai. Arpokrationos kai Souida peri tinon par'Isokratei lexeon. Isocratis Orationes partim doctorum virurom opera, partim meliorum exemplarium collatione, nunc demum multo quam antea emendatiores excusae..., Basileae 1555.

${ }^{301}$ Erasmus Rotterdamus. Wiele wydań, prawdopodobnie: De recta Latini Graecique sermonis pronunciatione, Des. Erasmi Roterodami dialogus. Eiusdem dialogus, cui titulus Ciceronianus, siue De optimo genere dicendi, Basileae 1558.

302 Andreas Althamer (Andreas Althammerus) (1500-1539), niemiecki humanista, teolog luterański. Wiele wydań, przykładowo: Conciliationes locorum scripturae, qui specie tenus inter se pugnare uidentur. Centuriae duae. Andrea Althamero authore..., Norimbergae 1548.

${ }^{303}$ Georg Purbach (Georg von Peuerbach, Georgius Puerbachius, Georgius Burbachius) (14231461), austriacki astronom i matematyk. Wiele wydań, przykładowo: Theoricae Novae Planetarvm Georgii Pvrbachij Germani. Quibus accesserunt: Ioannis de Monte Regio Disputationes, super deliramenta Theoricarum Gerardi Cremonensis. Item, Ioannis Eßler Maguntini, Tractaus utilis ante LX annos conscriptus, cui Titulum fecit, Specvlvm Astrologorvm, in quo Astrolog..., Basilae 1568.

${ }^{304}$ Cassianus Bassus (Cassiano Basso, Cassianus Scholasticus) (VI/VII w.), bizantyński prawnik, pisarz zajmujący się rolnictwem. Wiele wydań, przykładowo: Constantini Caesaris selectarum praeceptionum De agricultura libri viginti..., Lugduni 1541.

${ }^{305}$ Philip Melanchthon. Wiele wydań, przykładowo: Loci communes theologici recens collecti et recogniti a Philippo Melanthone, Vitebergae 1535.

${ }^{306}$ Juan Luis Vives (Juan Luis Vives March, Joannes Ludovicus Vives) (1493-1540), hiszpański humanista, filozof, pedagog. Prawdopodobnie: Ioannis Ludouici Vivis Valentini, De disciplinis libri 20. in tres tomos distincti..., Lugduni 1551.

${ }^{307}$ Wiele wydań, przykładowo: Aristotelus technes rhetorikes biblia 3. Aristotelis De Arte Rhetorica Libri Tres, Basileae 1529.

${ }^{308}$ Marcus Eremita, święty (Marco Eremita, Marcus von Ankyra) (zm. ok. 430), teolog, pisarz ascetyczny. Wiele wydań, przykładowo: Tou osiou Markou peri nomou pneumatikou kephálaia. Tou 
206 Luciani Samosatensis duo Thomi Graece 309

207 Joannis Varenii Sÿntaxis Graeca ${ }^{310}$

208 Xenophontis duo Thomi Graece ${ }^{311}$

209 Liricor[um] Carminum liber ${ }^{312}$

210 Eskini tragediae septe $[\mathrm{m}]^{313}$

211 Martini Cromeri oratio ${ }^{314}$

212 Eskini et Demostenis oratio[ne]s Graece ${ }^{315}$

213 Arriani de reb[us] gestis Alexandri Graece 316

214 Tipopographia[!] antiqua Romae Bartholomei Mariani ${ }^{317}$

215 Paraphrases Ar[istote]lis ${ }^{318}$

216 Linacer $^{319}$

autou perì tōn oioménōn ex érgōn dikaiousthai kephálaia. Sancti Marci heremitae de lege spirituali capitula. Eiusdem de iis, qui putant se iustificari ex operibus..., Haganoae 1531.

${ }^{309}$ Lucianus Samosatensis (Lucianus, Luciano di Samosata, Loukianós ho Samosateús) (ok. 125po 180), grecki satyryk, retor, sofista. Prawdopodobnie: Loukianou Hapanta. Luciani Samosatensis Opera, quae Graece extant, omnia, in duos tomos concinnè digesta..., Basileae 1545.

310 Joannes Varennius (Johannes Van de Waren, Ioannes Varennius Meclinensis) (1462-1536), gramatyk i filolog. Prawdopodobnie: Ioannis Varennii Syntaxis Graeca, ea potissimùm complectens, quae à Latinis dissentiunt Eiusdem... de Accentibus, libellus nouus..., Coloniae 1546 (lub wydanie z 1544 r.).

${ }^{311}$ Xenophon (Xenofont, Xenophont, Xenophontis) (ok. 430-355 p.n.e.). Przypuszczalnie: Xenophontos Apanta. Xenophontis oratoris et historici, propter synceram \& melle dulciorem Attici sermonis gratiam... opera, quae quidem graece extant, omnia, duobus tomis distincta..., Basileae [1545].

312 Johann Lange (Johann Lange Sylesius) (1503-1567), niemiecki humanista. Carminum lyricorum liber authore Ioannem Lango, Sylesio. Materia libri..., Wratislaviae 1548.

${ }^{313}$ Aeschylus (Aischýlos, Aeschylos) (525-456 p.n.e.). Prawdopodobnie: Aischylou Tragodiai epta. Aeschyli Tragoediae septem. A Francisco Robortello Vtinensi. Nunc primum ex manuscriptis... restitutae, Venetijs 1552 lub Aeschyli Tragoediae VII: Quae cùm omnes multo quàm antea castigatiores eduntur... Scholia in easdem, plurimis in locis locupletata... = Aischylu Tragōdiai 7, Promēteus desmōtēs, Hepta epi Thēbais, Persai, Agamemnōn, Choēphoroi, Eumenides, Hiketides.: Scholia eis tas autas tragōdias, b.m.w. 1557.

${ }^{314}$ Marcin Kromer (Martinus Cromerus, Martin Cromer, Martinus Chromer) (1512-1589), humanista, dyplomata, pisarz i historyk, biskup warmiński. Prawdopodobnie: Martini Cromeri Oratio, in Synodo Cracouiensi nuper habita..., Moguntiae 1550.

${ }^{315}$ Aeschines (Aischines, Eschines) (390-330 p.n.e.), grecki mówca. Demosthenes (Demostenes, Démosthone, Démosthène) (384-322 p.n.e.).Wiele wydań, prawdopodobnie: Aischinou tou rētoros kai Dèmosthenous Logoi, kata Ktēsiphōntos, kai peri stephanou. Aeschinis et Demosthenis Orationes inter se contrariae, longe omnium optimae, Patavii 1549.

316 Arrianus Flavius (Arrianus Arriano, Arrianos Flavios, Arrianus Nicomedensis) (95-175), grecki filozof i historyk. Wiele wydań, przykładowo: Arrianou Peri Alexandrou anavaseōs istoriōn biblia octō. Arriani De expeditione siue rebus gestis Alexandri Macedonum regis libri octo..., Basileae 1539 .

317 Bartolomeo Marliani (Giovanni Bartolommeo Marliani, Bartholomeus Marlianus) (14881566), włoski historyk i archeolog starożytny. Prawdopodobnie: Topographia antiquae Romae. Ioanne Bartholemaeo Marliano patritio Mediolan ensi authore, Lugduni 1534.

${ }^{318}$ Identyfikacja niepewna, być może: Totius naturalis philosophiae Aristotelis paraphrases per Iacobum Fabrum Stapulensem, recognitae iam, \& ab infinitis, quibus scatebant mendis, repurgatae: \& scholiis doctissimi uiri Iudoci Clichthouei illustratae..., Friburgi Brisgoiae 1540.

319 Thomas Linacre (Thomas Linacer, Thomas Linacrus Anglicus) (1460-1524), angielski lekarz, humanista. Prawdopodobnie jedno z wydań popularnego w XVI w. dzieła Thomae Linacri Britanni De emendata structura Latini sermonis libri sex, ..., Venetiis 1557. 


\section{Gra[m]matica Graeca Phillippi Melanctonis ${ }^{320}$ \\ 218 Cathehismus Christiane fidei ${ }^{321}$ \\ 219 Ludovici Vivis exerci[ti] linguae latinae ${ }^{322}$ \\ 220 Joannis Sturnii de amissa dicendi ratione ${ }^{323}$ \\ 221 Contradicto[ne]s Galeni in libros Hipocratis ${ }^{324}$ \\ 222 Colloquia Erasmi Rotherodami ${ }^{325}$ \\ 223 Nicolai Borbonii Nugar[um] libri $8^{326}$ \\ 224 De primatu Papae ${ }^{327}$ \\ 225 Ep[istu]lae Plinii s[e]c[un]di ${ }^{328}$ \\ 226 Copia verbor[um] Erasmi Rotherodami ${ }^{329}$ \\ 227 Hieronimi Comitis, de bello Turcar[um] Co[m]me[n]ntarii ${ }^{330}$ \\ 228 Geometria ${ }^{331}$ \\ 229 Geometria Polonice ${ }^{332}$}

320 Philip Melanchthon. Wiele wydań, przykładowo: Grammatica Graeca a Philippo Melanch. autore iam pridem recognita, atque multis in locis locupletata. Nicolaus Gerbellius..., Venetiis 1545.

${ }^{321}$ Identyfikacja niepewna, być może: Catechismus Christianae Fidei, ex verbo Dei conscriptus, b.m.w. 1550 lub jedno z wielu wydań J. Kalwina Catechismus, sive Christianae religionis institution communibus renatae nuper in Evangelio Genevensis Ecclesiae suffragiis recepta, \& vulgari quidem prius idiomate, nunc vero Latine etiam, quo de fidei illius synceritate passim aliis etiam Ecclesiis constet, Basileae 1538.

${ }^{322}$ Juan Luis Vives. Wiele wydań, przykładowo: Ioannis Lodouici Viuis Valentini Dialogistica linguae Latinae exercitatio. Annotationes praeterea in singula colloquia doctissimi viri Petri Mottae Complutensis, in Hispanae iunentutis gratiam adiecimus..., Venetiis 1562.

${ }^{323}$ Johann Sturm (Jean Sturm, Ioannes Sturmius) (1507-1589), pedagog, reformator szkolnictwa. Wiele wydań, przykładowo: Ioannis Stvrmii De amissa dicendi ratione \& quomodo ea recuperanda sit libri II, Argentorati 1550.

${ }^{324}$ Dzieła nie udało się zidentyfikować.

${ }^{325}$ Erasmus Rotterdamus. Wiele wydań, przykładowo: Familiarium colloquiorum Des. Erasmi Roterodami opus, ab autore postremum diligenter recognitum, emendatum, \& locupletatum, adiectis nouis aliquot lectu dignis colloquis. ..., Venetiis 1536.

${ }^{326}$ Nicolas Bourbon (Nicolaus Barbonius Vandoperanus, Nicolas Bourbon l'ancien) (1503-1550), francuski poeta, humanista. Nicolai Borbonii Vandoperani Lingonensis Nugarum libri octo. Ab autore recens aucti et recogniti. ..., Lugduni 1538 lub weneckie wydanie z $1540 \mathrm{r}$.

${ }^{327}$ Dzieła nie udało się zidentyfikować. Prawdopodobnie jedno z wydań zawierające Tractatus de potestate et primatu Papae powstały w 1537 r. (przypisywany $\mathrm{Ph}$. Melanchtonowi) i opublikowane w Strasburgu w $1540 \mathrm{r}$. anonimowo. Wersja niemiecka została opublikowana w Norymberdze w $1541 \mathrm{r}$. W 1580 r. traktat został włączony do Liber Concordiae, zbioru ksiąg wyznaniowych luteranizmu.

${ }^{328}$ Wiele wydań, przykładowo: C. Plinii Caecilii Secundi Nouocomensis Epistolarum libri decem..., Lugduni 1551.

${ }^{329}$ Erasmus Rotterdamus. Wiele wydań, przykładowo: Des. Erasmi Roterodami De duplici copia verborum ac rerum commentarii duo: multa accessione, novisque formulis locupletati..., Basileae 1560.

${ }^{330}$ Natale Conti (Natalis Comes, Hieronymus Comes) (1520-1582), włoski humanista, filolog, poeta. Commentarij Hieronymi Comitis Alexandrini de acerrimo, ac omnium difficillimo Turcarum bello, in insulam Melitam gesto, anno $1565 \ldots$... Noribergae 1566.

${ }^{331}$ Dzieła nie udało się zidentyfikować.

${ }^{332}$ Stanisław Grzepski (Stanislaus Grepsius) (1524-1570), grecysta, matematyk, autor pierwszej polskiej książki technicznej. Geometria, To iest Miernicka Nauka, po Polsku krótko napisana z Graeckich y z Lacińskich Ksiag: Naydziesz też iako naszy Miernicy zwykli mierzyć Imienie na Wtóki, albo 
230 Fabricatio hominis ${ }^{333}$

231 Organu[m] Ar[istote]lis ${ }^{334}$

232 Rhetorica Ciceronis ad Here[n]niu[m] $]^{335}$

233 Caelii de amplitudine Regni Dei ${ }^{336}$

234 Epitome Roterodami in Laurentiu[m] Valla[m] $]^{337}$

235 Justinus ${ }^{338}$

236 De conscribendis Ep[istoli]s Erasmi Roter[odami] ${ }^{339}$

237 Petri Mosellani in quintilianu[m] $]^{340}$

238 Sermo Samuelis Maczieowski in funere Sigismundi Regis ${ }^{341}$

239 Arithmetrica Frisii ${ }^{342}$

240 Politica Ar[istote]lis Graece ${ }^{343}$

241 De ratione victus Brudi Lusitani ${ }^{344}$

242 Psalteriu[m] Heobani Hesi ${ }^{345}$

na łany: Item, IUgerum Romanum iako wiele ma w sobie: Item, iako Wieże albo co inszego wysokiego zmierzyć, Kraków 1566.

${ }^{333}$ Wojciech Nowopolczyk (Wojciech Nowopolski, Albertus Novicampianus) (ok. 1504-1559), humanista, teolog, profesor Uniwersytetu Krakowskiego. Fabricatio hominis, a Cicerone libro secundo De natura deorum descripta. Cum annotationibus Alberti Nouicampiani. His accessit dissertatio eiusdem, utrum cor an iecur in formatione foetur consistat prius..., Cracovie 1551.

${ }^{334}$ Wiele wydań, przykładowo: Aristotelis Stagiritae Organum, hoc est, libri ad logicam attinentes, Boethio Seuerino interprete, nuper ex optimis exemplaribus Graecis recogniti. ..., Venetiis 1559.

${ }^{335}$ Cicero. Wiele wydań, przykładowo: Rhetoricorum ad C. Herennium libri 4. incerto auctore. Ciceronis De inuentione libri 2. Topica ad Trebatium, Oratoriae partitiones..., Venetiis 1554.

${ }^{336}$ Caelius Agostino Curio (Coelius Augustinus Curio) (1538-1567), włoski humanista. Coelii Secvndi Cvrionis De Amplitvdine Beati Regni Dei, Dialogi Sive Libri Dvo, Ad Sigismvndvm Avgvstvm Poloniae Regem... De amplitudine beati regni dei dialogi sive libri duo, b.m.w. 1554.

${ }^{337}$ Erasmus Rotterdamus. Wiele wydań, przykładowo D. Erasmii Roterodami in Laurentii Valae elegantiarum libros epitome, ... Eiusdem Copiae aliquot selectiores formulae, ad usum puerorum adcommodatae, Coloniae Agrippinae 1558.

${ }^{338}$ Prawdopodobnie Marcus Iunianus Iustinus (Iustinus Historicus) (III w.), historyk rzymski. Być może: Iustini Ex Trogi Pompeii historiis externis libri 44. His accessit ex Sexto Aurelio Victore De vita \& moribus Romanorum imperatorum epitome..., Lugduni 1560 lub inne wydanie.

${ }^{339}$ Erasmus Rotterdamus. Wiele wydań, przykładowo: De conscribendis epistolis opus Des. Erasmi Rot, Lugduni 1551.

${ }^{340}$ Petrus Mosellanus (Petrus M.Mosellanus, Peter Schade) (1493-1524), humanista, teolog. Prawdopodobnie: Annotationes Petri Mosellani Protogensis in clarissimas Auli Gellii Noctes Atticas. Reliqua autoris in Fabium Quintilianum eiusdem generis..., Basileae 1526.

${ }^{341}$ Samuel Maciejowski (1499-1550), biskup krakowski, kanclerz wielki koronny. Sermo habitus, per ... dominum Samuelē Macieiowski Episcopū Craco. Et R. P. Cācellariū. in funere Serenissimi dni Sigismundi Primi, Regis Poloniae etc., [Kraków 1548].

${ }^{342}$ Frisius Gemma (Frisius Reinerus Gemma) (1508-1555), niderlandzki lekarz, geograf, astronom. Gemmae Frisii Arithmeticae practicae methodus facilis, Lipsiae 1559 lub wydanie z 1562 r.

${ }^{343}$ Wiele wydań, przykładowo: Aristotelus politikōn biblia oktō = Aristotelis de optimo statu reipublicae libri octo, Parisiis 1556.

${ }^{344}$ Manuel Brudo (Brudus Lusitanus, Brudus Luscranus) (XVI w.), żydowski lekarz z Portugalii. Wiele wydań, przykładowo: De ratione victus in singulis febribus secundum Hippocratem, in genere et sigillatim libri 3. Authore Brudo Lusitano medico..., Venetiis 1559.

${ }^{345}$ Helius Eobanus Hessus (Eoban Koch, Eoban Hesse) (1488-1540), niemiecki humanista, filolog, historyk. Wiele wydań, przykładowo: Psalterium Davidis carmine redditum per Eobanum 
243 Medicinae infirmitatu[m] mulierum italice ${ }^{346}$

244 Dialectica Rodolffi ${ }^{347}$

245 Epigra[m]mata Joannis Zoteri ${ }^{348}$

246 Claudii Galeni de inaequali intemperie ${ }^{349}$

247 Emanuel $^{350}$

248 Jacobi Silvii de differe[n]tiis febriu[m] $]^{351}$

249 De verbis anomalis libri $2^{352}$

250 Georgii Agricolae de peste ${ }^{353}$

251 Morigae Encomiu[m] $]^{354}$

252 Hierardi Histrii ${ }^{355}$

253 Petri Stateri funebris oratio ${ }^{356}$

254 Svetonius $^{357}$

255 Simonis Maricii de academiis ${ }^{358}$

256 Bassia in opuscula ${ }^{359}$

257 Prolegomena Ioa[n]nis Hartungi in Homeru[m] $]^{360}$

Hessum. Cum annotationibus Viti Theodori Noribergensis, quae commentarii vice esse possunt. ..., Lipsiae 1562.

${ }^{346}$ Dzieła nie udało się zidentyfikować.

${ }^{347}$ Rudolf Agricola (Rodolphus Agricola Phrisius, Rudolf Hausmann) (1443-1485), niderlandzki humanista i filozof. Wiele wydań, przykładowo: Rodolphi Agricolae Phrisii De Inventione Dialectica Libri Omnes, Coloniae Agrippinae 1563.

${ }^{348}$ Johann Heil (Johannes Soeter, Johan Soter) (zm. ok. 1544), drukarz działający w Kolonii i w Solingen. Wiele wydań, przykładowo: Epigrammata Graeca veterum elegantissima, eademque Latina ab utriusque linguae uiris doctissimis uersa... Anagnoste, ta epigrammata..., Friburgi Brisgoiae 1544.

${ }^{349}$ Claudius Galenus. Wiele wydań, przykładowo: Claudii Galeni Pergameni De temperamentis libri 3. De inaequali intemperie liber vnus..., Lugduni 1558.

${ }^{350}$ Dzieła nie udało się zidentyfikować.

${ }^{351}$ Jacques Dubois (Iacobus Sylvius, Jacques du Bois) (1478-1555), francuski lekarz, anatom. Wiele wydań, przykładowo: Iacobi Sylvii Medicae Rei Apvd Parrhisios interpretis regii cõmmentarius in Claudii Galeni duos libros de differentiis febrium, Basileae 1556.

${ }^{352}$ Guillaume Morel (Guilielmus Morelius) (1505-1564), francuski drukarz, wydawca, thumacz. Wiele wydań, przykładowo: De verbis anomalis libri II De verbis quae difficiliora sunt ad investigandum unde oriantur, ad sua themata revocandis Liber, Parisiis 1553.

${ }^{353}$ Georg Agricola (Georg Agricola Bermannus, Georgius Agricola medicus) (1494-1555), niemiecki humanista, lekarz, przyrodnik. Georgii Agricolae De peste libri tres, Basileae 1554.

${ }^{354}$ Erasmus Rotterdamus. Wiele wydań, przykładowo: Moriae encomium, id est, stulticiae laudatio, ludicra declamatione tractata per Des. Erasmum Roterodamum, cum quibusdam alijs, Basileae 1551.

${ }^{355}$ Dzieła nie udało się zidentyfikować. Być może autorem dzieła był Stephanus Consul Histrianus (Console, Stefano Istriano) (1521-1568), protestancki kaznodzieja i pisarz.

${ }^{356}$ Dzieła nie udało się zidentyfikować.

${ }^{357}$ Gaius Suetonius Tranquillus (Svetonius) (ok. 69-122), rzymski historyk. Dzieła nie udało się zidentyfikować.

358 Szymon Marycjusz (Szymon Marycki, Simon Maricius, Szymon z Pilzna, Koziołek, Maricjusz, Czystochlebski) (1516-1574), humanista, pedagog, profesor Uniwersytetu Krakowskiego. Simonis Maricii Pilsnensis, Jureconsulti, De Scholis seu Academiis libri duo, Cracoviae 1551.

${ }^{359}$ Bassiano Landi (Bassianus Landus) (15?? - ok. 1563), włoski lekarz, filozof. Bassiani Landi Placentini philosophi et medici Opuscula, Patavii 1552.

${ }^{360}$ Johann Hartung (Ioannes Hartungus), niemiecki humanista, filolog. Prolegomena Ioannis Hartvngi in tres priores Odysseae Homeri Rapsodias, Francoforti 1539. 
258 Disputatio Theologica Crolmani ${ }^{361}$

259 Aphtonii Zophistae Progÿmnasmata ${ }^{362}$

260 Henrici Glareani Arithmetrica ${ }^{363}$

261 Joannis Baptistae de Caesaribus libri $3^{364}$

262 Martini Peresei de traditionib[us] Apostolicis ${ }^{365}$

263 Epitetorum omnium Ioa[n]nis Rasii textor[es] $]^{366}$

264 Arriani de reb[us] gestis Alexandri ${ }^{367}$

265 Antiquitates Civitatis Romane italic ${ }^{368}$

266 Erasmi de ratione co[n]cionandi ${ }^{369}$

267 Cathehismus Ecclesiae genevensis ${ }^{370}$

268 Vergilii Polidori de Prodigiis ${ }^{371}$

269 eiusdem de reru[m] inventarib[us] $]^{372}$

270 Viaticu[m] Novu[m] Casparis Velfii ${ }^{373}$

${ }^{361}$ Dzieła nie udało się zidentyfikować.

${ }^{362}$ Aphthonius Antiochenus (Aphthonius Sophista) (IV/V w.), grecki retor. Wiele wydań, przykładowo Aphthonii sophistae Progymnasmata, partim a Rodolpho Agricola, partim a Ioanne Maria Catanaeo latinitate donate..., Lugduni 1555.

${ }^{363}$ Henricus Loriti Glareanus (Henricus Loritus Glareanus) (1488-1563), szwajcarski humanista, geograf, pisarz muzyczny. Wiele wydań, przykładowo: De sex arithmeticae practicae speciebus, Henrici Glareani epitome, Parisiis 1554.

${ }^{364}$ Giovanni Battista Cipelli. Prawdopodobnie: In hoc volumine haec continentur. Ioannis Baptistae Egnatij Veneti de Caesaribus libri 3. à dictatore Caesare ad Constantinum Palaeologum, hinc à Carolo Magno ad Maximilianum Caesarem ..., Venetiis 1516 lub florenckie wydanie z $1519 \mathrm{r}$.

${ }^{365}$ Martin Pérez de Ayala (Martinus Peresius Aiala) (1504-1566), hiszpański teolog. Wiele wydań, przykładowo: De diuinis, apostolicis atque ecclesiasticis traditionibus, deque authoritate ac vi earum sacrosancta, adsertiones ceu libri decem..., Coloniae 1560.

${ }^{366}$ Jean Tixier de Ravisi (Iean Ravis Tissier, Ioannes Rauisius Textor Niuernensis) (1480-1524), francuski humanista, filolog. Prawdopodobnie jedno z wielu wydań: Ioannes Rauisij Textoris Niuernensis Epithetorum opus absolutissimum..., [Basileae 1571].

${ }^{367}$ Prawdopodobnie łacińskie wydanie dzieła wpisanego do inwentarza pod numerem 184/213. Wiele wydań, przykładowo: Arriani Nicomedensis noui Xenophontis appellati De rebus gestis Alexandri Magni regis Macedonum libri octo, ..., Basileae 1554.

${ }^{368}$ Identyfikacja niepewna. Być może Lucio Mauro, Le antichita de la citta di Roma. Breuissimamente raccolte da chiunque ne ha scritto, ò antico ò moderno; per..., Venetia 1556 lub Andrea Palladio, L'antichita di Roma di m. Andrea Palladio. Raccolta breuemente da gli auttori antichi, \& moderni. Nuouamente posta in luce, Venetia 1555. Ale możliwy także znany już Bartolomeo Marliani, L'antichita di Roma, di m. Bartholomeo Marliano, tradotti [!] in lingua volgare per m. Hercole Barbarasa da Terni, Roma 1548.

${ }^{369}$ Erasmus Rotterdamus. Wiele wydań, przykładowo: Des. Erasmi Rot. Ecclesiastae siue de ratione concionandi libri quatuor, postremum ab autore recogniti..., Basileae 1535.

${ }^{370}$ Wiele wydań, przykładowo: Catechismus ecclesiae Genevensis hoc est, formula erudiendi pueros in doctrina Christi [Jean Calvin], Genevae 1560.

${ }^{371}$ Polidoro Vergilio (Polidorus Virgilius Vrbinas) (1470-1555), włoski humanista. Wiele wydań, przykładowo: Polydori Vergilii Vrbinatis Dialogorum de prodigiis libri tres, Basileae 1531.

${ }^{372}$ Wiele wydań, przykładowo: Polydori Vergilii Urbinatis De Rerum Inventoribus libri octo. Eiusdem in orationem Dominicam commentariolum ..., Francoforti 1549.

${ }^{373}$ Caspar Wolf (Gaspar Volfius, Casparus Wolphius) (1532-1601), szwajcarski lekarz, humanista, filolog. Viaticum novum de omnium fere particularium morborum curatione liber, authoris innominati quidem ... nunc primum in lucem editus per Casparum Vvolphium..., Tiguri 1565. 
271 Philostratis Lemni Historiae de vitae Apolonii ${ }^{374}$

272 Leoneli Fanentini Practica Medicinalis ${ }^{375}$

273 Forma Ecclesiastici Ministerii ${ }^{376}$

274 Ludovici Vivis de ani[m]a et vita libri $3^{377}$

275 Erasmi Stellae de Gemmis ${ }^{378}$

276 Constantini Privilegiu[m] $]^{379}$

277 Fuschii de Stirpiu[m] Historia ${ }^{380}$

278 Montani in Aphorismos Hippocratis lectio[ne]s $\mathrm{s}^{381}$

279 Simplex narratio Ioa[n]nis Utenhovii ${ }^{382}$

280 De coena Dom[in]i Joachimi Veshvali ${ }^{383}$

281 Confessio Christiana Authore Bezo ${ }^{384}$

282 Cardanus de malo medicor[um] recentiu[m] $\mathrm{Usu}^{385}$

${ }^{374}$ Philostratus Lemnius (Philostratus Maior, Philostratos Flavios, Filostrato di Lemnio) (ok. 190-
230), pisarz, filozof, sofista. Philostrati Lemnij senioris Historiae de uita Apollonij libri 8... Eusebij
Caesariensis Aduersus Hieroclem, qui ex Philostrati historia Apollonium Christo aequiparate con-
tendebat, confutatio, siue apologia ..., Coloniae 1532 .
${ }^{375}$ Leonello Vittori (Leonell Vettori, Leonellus Faventinus, Leonello de' Vittori) (1450-1520),
włoski lekarz, filozof. Wiele wydan,, przykładowo: Practica medicinalis Leonelli Fauentini de Victoriis,
cum scholiis Ioannis Kufneri. De aegritudinibus infantium, eodem authore, tractatus..., Lugduni 1554.
376 Jan Łaski (Joannes a Lasco, Johann von Lasco) (1499-1560), polski humanista, reformator religijny. Wiele wydań, prawdopodobnie: Forma ac ratio tota ecclesistici ministerij, in peregrinorum, potissimùm verò Germanorum Ecclesia: insituta Londini in Anglia..., anno post Christum natum $1550 \ldots$, [Emdem 1555-1556].

377 Juan Luis Vives. Wiele wydań, przykładowo: Ioannis Lodovici Vivis Valentini De Anima \& vita Libri tres. Eivsdem Argvmenti Viti Amerbachii de Anima Libri IIII. ..., Lugduni 1555.

${ }^{378}$ Erasmus Stüler (Erasmus Stella, Erasmus Libanotanus) (1460-1521), niemiecki lekarz, historyk. Erasmi Stellae Libanothani Viri Clariss. De gemmis libellus unicus. Plinius secundus de gemmis, Argentorati ok. 1530.

${ }^{379}$ Prawdopodobnie: Donationis, quae Constantini dicitur privilegium Bartholomeo Pincerno de monte arduo ad Iulium II. Pont. Max. interprete... Nicolavs de Cusa... de donatione Constantini. Antonivs archiepiscopus Florentinus, de eadem re. R. P. D. Hieronymus Paulus Catthalanus... de eadem donatione, Basilae ok. 1520.

${ }^{380}$ Leonhart Fuchs (Leonhardus Fuchsius, Leonhard Fuchs aus Wemding) (1501-1566), niemiecki lekarz, botanik. Wiele wydan, przykładowo: Leonharti Fuchsii medici, Primi de stirpium historia commentariorum tomi viuae imagines, in exiguam angustioremque formam contractae..., Basileae 1549.

${ }^{381}$ Giovanni Battista da Monte. Wiele wydań, przykładowo: Io. Baptistae Montani, Veronensis, Philosophorvm Ac Medicorvm Omnivm Svae Tempestatis Facile Principis, Expectatissimae In Aphorismos Hippocratis Lectiones..., Venetiis 1553-1554.

${ }^{382}$ Jan Utenhove (Johannes Utenhovius, Jan Uytenhove) (1516-1566), niderlandzki teolog, kalwinista. Simplex et fidelis narratio de instituta ac demum dissipata Belgarum, aliorumque peregrinorum in Anglia, ecclesia... Per Ioannem Vtenhouium Gandauum..., Basilae 1560.

${ }^{383}$ Joachim Westphal (Ioachimus Vuestphalus) (1510-1574), niemiecki teolog i pastor luterański. Prawdopodobnie: Apologia Confessionis De Coena Domini, Contra Corruptelas et calumnias Ioannis Caluini scripta a Ioachimo Vuestphalo Ecclesiaste Hamburgensi, Ursellis 1558.

${ }^{384}$ Theodore de Beze (Theodorus Beza, Théodore de Besze) (1519-1605), francuski teolog protestancki, następca Jana Kalwina. Prawdopodobnie: Confessione della fede christiana di $m$. Theodoro Beza Vezeli. Nella quale è confermata la verità, e sono rifiutate le superstitioni contrarie, [Ginevra] 1560.

${ }^{385}$ Girolamo Cardano (Hieronimus Cardano, Geronimo Cardano) (1501-1576), włoski matematyk, lekarz, filozof, astrolog. Hieronymi Cardani medici mediolanensis, De malo recentiorum 
283 Brasavolla de medicam[en]t[is] purga[n]tib[us] $]^{386}$

284 Montanus in libru[m] Epidemioru[m] $]^{387}$

285 Montani in quartam Fen Avicennae ${ }^{388}$

286 Historia frum[en]tor[um] Roberti Dordonii ${ }^{389}$

287 Examen Sÿrupor[um] Brasavollae ${ }^{390}$

288 Arreteus $^{391}$

289 de fossilib[us] Gesneri ${ }^{392}$

290 Theophrasti de causis morbor[um] $]^{393}$

291 Amati Lusitani Curationu[m] medicinaliu[m] Centuria prima ${ }^{394}$

292 Simeonis Caeti de Cibarioru[m] facultate ${ }^{395}$

293 Pauli Eginetae opera ${ }^{396}$

medicorum medendi usu libellus, centum errores illorum continens..., Venetijs 1545 lub wydanie z $1536 \mathrm{r}$.

${ }^{386}$ Dzieła nie udało się zidentyfikować. Jeśli autorem był Antonio Musa Brasavola (1500-1555), to wówczas tytuł powinien brzmieć: ... De medicamentis tam simplicibus, quam compositis catharticis, quae vnicuique humori sunt propria, tractatus insignis... (przykładowo wydanie lyońskie z 1555 r.). Natomiast jeśli założymy, że autor jest błędny, wówczas tytuł de medicamentis purgantibus można przypisać Gabrielle Falloppio ... De simplicibus medicamentis purgantibus, tractatus non minus elegans, quàm utilis..., Venetiis 1565.

${ }^{387}$ Giovanni Battista da Monte. Io. Baptistae Montani Medici Veronnensis In tertium primi Epidemiorum sectionem explanationes. A Valentino Lublino Polono collectae, Venetijs 1554.

${ }^{388}$ Giovanni Battista da Monte. Io. Baptistae Montani Medici Veronensis in qvartam fen primi canonis Auicennae, lectiones: A Valentino Lublino polono collectae, Venetiis 1556.

${ }^{389}$ Rembert Dodoens (Rembertus Dodenaeus) (1517-1585), niderlandzki lekarz i botanik. Prawdopodobnie: Historia frumentorum, leguminum, palustrium et aquatilium herbarum, ac eorum, quae è pertinent: Remberto Dodonaeo... auctore..., Antverpiae 1569.

${ }^{390}$ Antonio Musa Brasavola. Wiele wydań, przykładowo: Antonii Musae Brasavoli Ferrariensis, Examen omnium syruporum, quorum publicus vsus est..., Lugduni 1546.

${ }^{391}$ Prawdopodobnie jedno z dzieł greckiego lekarza Aretaeusa (Aretaeus Cappadocius, Aretaeus Medicus, Areteo di Cappadocia). Przykładowo: Aretaiou Kappadokou Peri aition kai semeion xeon kai kronion pathon bibl.d oxeon kai kronion therapeutika bibl. Aretaei Cappadocis De acutorum ac diuturnorum morborum causis et signis, lib. 4. De acutorum, ac diuturnorum morborum curatione lib. 4, Parisiis 1554.

${ }^{392}$ Conrad Gesner. Prawdopodobnie drugi egzemplarz dzieła: De omni rerum fossilium genere, gemmis, lapidibus, metallis, et huiusmodi, libri aliquot, plerique nunc primum editi. Opera Conradi Gesneri... Zob. poz. 184/164.

${ }^{393}$ Paracelsus (Philippus Aureolus Theophrastus Bombastus von Hohenheim, Theophrastus Paracelsus) (1493-1541), szwajcarski lekarz, alchemik, astrolog, zwany ojcem nowożytnej medycyny. Medicorum et philosophorum summi, Aureoli Theophrasti Paracelsi, eremitae, libri quinque de causis, signis \& curationibus morborum ex Tartaro vtilissimi. Opera et industria nobilis viri Adami a Bodenstein..., Basileae 1563.

${ }^{394}$ Joao Rodrigues de Castello Branco. Amati Lvsitani Medici Physici Praestantissimi, Curationum Medicinalium Centuria prima: multiplici variaque rerum cognitione referta, Florentiae 1551.

${ }^{395}$ Simeon Seth (Simeon Sethus, Simone Setto) (XI w.), grecki lekarz, pisarz. Symeonos magistrou Antiocheias tou Sethi, Syntagma katà stoicheion, perì trophon dynameon. Symeonis Sethi magistri Antiochiae, Syntagma per literarum ordinem, de cibariorum facultate, ..., Basileae 1538.

${ }^{396}$ Paulus Aegineta (Aeginitus Medicus, Paolo Egineta) (ok. 625-690), bizantyński lekarz. Wiele wydań, przykładowo: Pauli Aeginetae medici Opera. A Ioanne Guinterio Andernaco medico exercitatissimo summique iudicii conuersa, \& illustrata commentariis..., Venetiis 1553. 
294 Dioscorides Graecolatinus ${ }^{397}$

295 Horribasii Collectanea ${ }^{398}$

296 Cardani de Subtilitate ${ }^{399}$

297 Garciae Lopii de re medica Co[m]mentarii ${ }^{400}$

298 Philotei in Aphorismos Hippocratis ${ }^{401}$

299 Euonimus Gesneri ${ }^{402}$

300 Vesalii Chirurgia Magna ${ }^{403}$

301 Marsilii Phicini, de vita ${ }^{404}$

302 Morbi Gallici curandi r[ati]o varior[um] author[um] $]^{405}$

303 Hipoliti Brilii, De Colico affectu ${ }^{406}$

304 Hipocratis de morbis vulgaribus liber s[e]c[un]d[u] $\mathrm{s}^{407}$

${ }^{397}$ Dzieła nie udało się zidentyfikować. Być może dwujęzyczne wydanie: Pedacii Dioscoridae Anazarbei De medica materia libri sex. A Marcello Virgilio secretario Florentino Latinitate donati cum eiusdem commentationibus ..., Florentiae 1523 lub Pedakiou Dioskoridou Anazarbeōs Peri hylēs iatrikēs biblia 5; tou autou Peri dēlētēriōn pharmakōn kai tōn autōn prophylakēs; tou autou Peri iobolōn en hō kai peri lyssōtos kynos biblion 1; tou autou Peri sēmeiōseōs tōn hyper iobolōn dedēgmenōn biblion 1; tou autou Peri therapeias tōn hyper iobolōn dedēgmenōn biblion 1 Pedacii Dioscoridae De medica materia libri V: de letalibus venenis eorumque praecautione et curatione..., Coloniae 1529/1530.

${ }^{398}$ Oribasius (Oreibasios, Oribasius Pergameus Sardianus, Oribasio di Pergamo) (ok. 325-403), grecki lekarz. Prawdopodobnie: Oribasii Sardiani collectorum Medicinalium, libri XVII, Qui ex magno septuaginta librorum volumine ad nostram aetatem soli pervenerunt Ioanne Baptista Rasario..., Parisiis 1555.

${ }^{399}$ Girolamo Cardano. Wiele wydań, przykładowo: Hieronymi Cardani... De subtilitate libri 21 ..., Lugduni 1559.

${ }^{400}$ Garcias Lopes (XVI w.), portugalski lekarz. Garciae Lopii Lusitani, Portalegrensis medici, Commentarii de varia rei medicae lectione, medicinae studiosis non parum vtiles..., Antverpiae 1564.

401 Theophilus Protospatharius (Theophilius Protospatarius, Theophilius Medicus) (IX w.), grecki lekarz. Philothei medici praestantissimi Commentaria in aphorismos Hippocratis. Nunc primum e graeco in Latinum sermonem conuersa..., Venetijs 1549.

${ }^{402}$ Prawdopodobnie: Euonymus. Conradi Gesneri medici et philosophi Tigurini. De remedijs secretis, liber physicus, medicus, \& partim etiam chymicus, \& oeconomicus in vinorum diuersi saporis apparatu, medicis \& pharmacopolis omnibus praecipuè necessarius..., Zurigo 1569.

${ }^{403}$ Andreas Vesalius. Andreae Vessalii Bruxellensis... Chirurgia Magna in septem libros digesta: in qua nihil desiderari potest, quod ad perfectam, atque integram de curandis humani corporis malis, methodum pertineat..., Venetiis 1568 lub wydanie z 1569 r. (także weneckie).

${ }^{404}$ Marsilio Fichino (Marsilius Ficinus, Marsile Ficin) (1433-1499), włoski humanista, lekarz, astrolog, filozof, teolog, poeta. Marsilius Ficinus Florentinus de triplici vita scilicet sana, longa et celitus, vna cum textu seu regimine sanitatis Salerni, Argentorati 1511 lub weneckie wydanie z $1518 \mathrm{r}$.

${ }^{405}$ Morbi gallici curandi ratio exquisitissima, à uarijs, ijsdemque peritissimis medicis conscripta: nempe Petro Andrea Matthaeolo Senensi. Ioanne Almenar Hispano. Nicolao Massa Veneto. Nicolao Poll... Benedicto de Victorijs, Fauentino..., Basileae 1536 lub lyońskie wydanie z tego samego roku.

${ }^{406}$ Ippolito Brilli (Jeronimo Brilli, Hyppolytus Brillus) (XV/XVI w.), lekarz. Hyppoliti Brilli de lendenaria artium \& medicinae doctoris De colico affectu tractatus, ..., Venetijs 1537.

${ }^{407}$ Hippocrates. Hippocratis Coi, medicorum omnium facile principis Liber secundus de morbis vulgaribus, difficilimus \& pulcherrimus: olim à Galeno Commentarijs illustratus, qui temporis iniuria interciderunt: nunc verò penè in integrum restitutus, commentarijs sex \& Latinitate donatus. Anutio Foësio mediomatrico medico author..., Basileae 1560. 


\section{Svigmica ars Jozephi Strucii ${ }^{408}$}

306 Argenterii de Consultationib[us] medicis ${ }^{409}$

307 Joannis Calvini in Ep[istu]lam ad Romanos ${ }^{410}$

308 Multiplicia metra aurea Alexa[n]dri Sanuto ${ }^{411}$

309 Vocabularius utriusq[ue] iuris $^{412}$

310 Alexandri Traliani ars medica ${ }^{413}$

311 Explicatio Orthodoxae fidei Petri Carolini ${ }^{414}$

312 Catechesis Christianismi Graeca ${ }^{415}$

313 De poligamia ${ }^{416}$

314 Petri Barri Enchiridion medicinale ${ }^{417}$

315 Farrago iuris Joannis Cervi ${ }^{418}$

316 Matheoli Apologia adv[er]sus Amatu[m] Lusitanu[m] $]^{419}$

\footnotetext{
${ }^{408}$ Józef Struś (Josephus Struthius, Joseph Struth, Strucius, Strusiek, Struszek) (1510-1568), humanista, lekarz Zygmunta Starego i Zygmunta Augusta, burmistrz Poznania. Sphygmicae artis iam mille ducentos annos perditae et desideratae libri $V$ zostały opublikowane po raz pierwszy w $1540 \mathrm{r}$. w Bazylei, ale do naszych czasów zachowały się egzemplarze kolejnych wydań od 1555 r. Sphygmicae artis Iam Mille Dvcentos annos perditae \& desideratae Libri V. A Iosepho Strvthio Posnaniense Medico recens conscripti, Basileae 1555.

${ }^{409}$ Giovanni Argenterio. Wiele wydań, przykładowo: Ioannis Argenterii Castellonouensis... De consultationibus medicis siue (vt vulgus vocat) de collegiandi ratione liber, Florentiae 1551.

410 Jean Calvin. Joannis Calvini Commentarii in Epistolam Pauli ad Romanos, Strasbourg 1540.

${ }^{411}$ Alessandro Sanuto vel Sanudo (XVI w.), wenecjanin, poeta, prawdopodobnie przebywał w Polsce w latach 1561-1572. Mvltiplicia Metra Avrea Cvm Originis Mvndi... Et Mortis Hvmanae Resvrrectionisqve Domini Iesv Cristi Redemptoris Nostri, Tvm De Consvlvm Cracouiensium felici noua Electione... Alexandri Sanuto..., Cracoviae ok. 1571.

412 Wiele wydań, przykładowo: Vocabularius vtriusque iuris difficillimas quasque voces iuxta receptos iuris interpretes edifferent..., Venetiis 1564.

${ }^{413}$ Alexander Trallianus. Dzieła nie udało się zindentyfikować.

${ }^{414}$ Peter Károli (Petrus Carolini, Petrus Carolinus) (1543-1576), węgierski teolog, pastor luterański. Brevis, Ervdita, Et Perspicva Explicatio Orthodoxae Fidei de vno vero Deo, Patre, Filio \& Spiritu sancto, aduersus blasphemos Georgij Blandratae, [et] Francisci Dauidis errores, Libris duobus compraehensa. Avthore Petro Carolino Pannonio, Pastore Varadiensis Ecclesiae, Vitebergae 1571.

${ }^{415}$ Prawdopodobnie jedno z wydań Catechesis Christianismi w języku greckim, przykładowo wydanie lipskie z ok. 1562 r.

${ }^{416}$ Theodore de Beze. Tractatio de polygamia, et diuortiis: in qua et Ochini apostatae pro polygamia, et Montanistarum ac aliorum aduersus repetitas nuptias argumenta refutantur..., Genevae 1568 lub wydanie z 1571 r. (także genewskie).

${ }^{417}$ Pietro Bairo (Pietrus Bairus) (1468-1558), włoski lekarz. Wiele wydań, przykładowo: Petri Bayri Taurinensis De medendis humani corporis malis enchiridion, quod uulgò Veni mecum uocant..., Basileae 1560.

418 Jan Cervus (Ioannes Cervus, Jan Tucholczyk, Jan Jelonek z Tucholi) (zm. ok. 1557), autor pism prawniczych i gramatycznych, wykładowca na Uniwersystecie Krakowskim, rektor szkoły katedralnej we Lwowie. Wiele wydań, przykładowo: Farraginis actionum iuris civilis et provincialis Saxonici, municipalisque Maydeburgensis libri septem per Ioannem Cervum Tucholiensem collecti..., Cracoviae 1558.

${ }^{419}$ Pietro Andrea Mattioli. Wiele wydań, przykładowo: Petri Andreae Matthioli Senensis serenissimi principis Ferdinandi archiducis Austriae \&c. Medici, Commentarii secundo aucti, in libros sex Pedacii Dioscoridis Anazarbei de medica materia... His accessit eiusdem apologia aduersus Amathum Lusitanum, quin et censura in eiusdem enarrationes, Venetiis 1558.
} 
317 Joannis Calvini in librum Josue e $^{420}$

318 Enchiridion militis Christiani Erasmi Rotherodami ${ }^{421}$

319 Scholia Joa[n]nis Agricolae in Cura[n]di arte Galeni ${ }^{422}$

320 Jasonis Pratensis de Cerebri morbis ${ }^{423}$

321 Donati Aiciaioli in Politica Ar[istote]lis ${ }^{424}$

322 Confessio Orthodoxae fidei Ministror[um] Helvaetiae ${ }^{425}$

323 De origine pestis Patavinae ${ }^{426}$

324 Confessio Polonor[um] $]^{427}$

325 Institutio[ne]s medicinae Fuxiii ${ }^{428}$

326 De aeterno Dei filio Simleri ${ }^{429}$

327 Francisci Patricii De institutione Repub[licae $]^{430}$

328 Dionis de bellis Romanis Italice ${ }^{431}$

329 Responsio Hosii con[tra] Jo[anne]m Lascum ${ }^{432}$

420 Jean Calvin. Joannis Calvini in librum Josue brevis commentarius, quem paulo ante mortem
absolvit..., Genevae 1564 .
421 Erasmus Rotterdamus. Wiele wydań, przykładowo: Enchiridion militis christiani, saluberri-
mis praeceptis refertum autore De S. Erasmo Rotterodamo. Eiusdem De praeparatione ad mortem
Liber..., Basileae 1551.
422 Johann Agricola (Ioannes Agricola Ammonius) (1496-1570), niemiecki lekarz. Scholia copio-
sa in Therapeuticam methodum, id est, absolutissimam Claudij Galeni Pergameni curandi artem...,
Augustae Vindelicorum 1534.
423 Jason Pratensis (Iason Zyriceus Pratensis) (1486-1558), niderlandzki humanista, lekarz.
D. Iasonis Pratensis Zyricei medici clarissimi De cerebri morbis: hoc est, omnibus fermè (quoniam
à cerebro male affecto omnes... morbi oriuntur) curandis liber.., Basileae 1549.
424 Donato Acciaiuoli (Donatius Acciaiolius) (1428-1478), włoski pisarz, humanista. Donati
Acciaioli In Aristotelis libros octo Politicorum commentarii, nunc primùm in lucem editi..., Venetiis
1566. 1566.

${ }^{425}$ Confessio et expositio simplex orthodoxae fidei, \& dogmatum Catholicorum syncerae religionis Christianae, concorditer ab ecclesiae Christi ministris, qui sunt in Helvetia, Tiguri, Berne..., Tiguri 1566 lub wydanie z 1568 r. (również zuryskie).

${ }^{426}$ Bassiano Landi (Bassianus Landus) (zm. ok. 1563), lekarz, filozof, pisarz. De origine et causa pestis Patauinae, anni M.D.L.V. Per Bassianum Landum, Venetiis 1555.

${ }^{427}$ Dzieła nie udało się zidentyfikować.

${ }^{428}$ Leonhart Fuchs. Wiele wydań, przykładowo: Institutionum Medicinae, ad Hippocratis, Galeni aliorumque veterum scripta rectè intelligenda mirè utiles Libri quinque Leonharto Fuchsio medico..., Venetiis 1555.

${ }^{429}$ Josias Simmler (Iosias Simlerus) (1530-1576), szwajcarski pastor, teolog, historyk. De aeterno Dei filio domino et seruatore nostro Iesu Christo, \& de spiritu sancto, aduersus veteres \& nouos antitrinitarios, id est Arianos, Tritheitas, Samosatenianos \& Pneumatomachos, libri quatuor Iosia Simlero Tigurino author..., Tiguri 1568.

${ }^{430}$ Francesco Patrizi (Franciscus Patricius Senensis) (1413-1494), włoski humanista, pedagog, filozof. Wiele wydań, przykładowo: Francisci Patricii Senensis... De institutione reipublicae. libri nouem, historiarum sententiarumque varietate refertissimi..., [Parigi] 1534.

${ }^{431}$ Dio Cassius Cocceianus (Díōn Kássios Kokkỉianós, Cassius Dio Cocceianus) (155-235), historyk rzymski pochodzenia greckiego. Przypuszczalnie jedno z kilku wydań po włosku: Dione Delle guerre de Romani..., przykładowo Venetia 1548.

${ }^{432}$ Stanisław Hozjusz (Hos, Hosius, Hosz, Hozyusz, Osius, Stanislaus Cracoviensis) (15041579), polski humanista, poeta, dyplomata, biskup chełmiński i warmiński, kardynał, teolog, jeden z najważniejszych przywódców polskiej i europejskiej kontrreformacji. Prawdopodobnie: Brevis Ac Compendiaria Responsio, Ad Collectos certos quosdam ex Erasmo Albero, per Stanislaum Hosium, 
330 Montani explanatio[ne]s in libru[m] Galeni de arte Cura[n] $\mathrm{di}^{433}$

331 Examen omnium Loch Brasavollae ${ }^{434}$

332 Fernelii maedicina ${ }^{435}$

333 Bachanelii de co[n]sensu medicor[um $]^{436}$

334 Enarratio[ne]s medicinales Fra[n]cisci Valeriolae ${ }^{437}$

335 Montani in p[ri]mam Fen Avicennae explanatio ${ }^{438}$

336 eiusdem in parva[m] arte Galeni ${ }^{439}$

337 Levini Legni occulta n[atura]e miracula ${ }^{440}$

338 Nicolai Bresii Co[m]mentarii in arte medica[m] Galeni ${ }^{441}$

339 Montani in novu[m] libru[m] Rasis ${ }^{442}$

340 Gabrielis Falopii Anathomia ${ }^{443}$

341 Theophrasti de plantis Historia Graeca ${ }^{444}$

titulo Varmiensem Episcopum, articulos, de doctrina Ioannis à Lasco: atq[ue] huc in Poloniam transmissos, simulque et ad libellum ipsius nuper editum De oppresso verius..., Pinczoviae 1559.

${ }^{433}$ Giovanni Battista da Monte. Io. Baptistae Montani medici Veronensis in libros Galeni de arte curandi ad Glauconem explanationes, Venezia 1554 lub wydanie lyońskie z 1556 r.

${ }^{434}$ Antonio Musa Brasavola. Wiele wydań, przykładowo: Antonij Musae Brassauoli medici ferrariensis Examen omnium loch, id est, linctuum, suffuf, id est, puluerum, aquarum, decoctionum, oleorum, quorum apud ferrarienses pharmacopôlas vsus est..., Lugduni 1555.

${ }^{435}$ Jean Fernel (Ioannes Farnelius Ambianatis) (1497-1558), francuski lekarz, filozof, matematyk. Wiele wydań, przykładowo: Ioan. Fernelii Ambiani Medicina, physiologiam, pathologiam, methodumque complectens, Venetiis 1555.

${ }^{436}$ Giovanni Baccanelli (Ioannes Bacchanellus) (1500-1571), włoski lekarz. Wiele wydań, przykładowo: Ioannis Baccanelij medici Regiensis, De consensu medicorum in curandis morbis, libri quatuor. Eiusdem De consensu medicorum in conoscendis simplicibus liber, Venetiis 1556.

${ }^{437}$ François Valleriola (Franciscus Valleriola) (1504-1580), francuski lekarz. Enarrationum medicinalium libri sex. Item Responsionum liber vnus. Francisco Valleriola medico autore..., Lugduni 1554 lub weneckie wydanie z $1555 \mathrm{r}$.

${ }^{438}$ Giovanni Battista da Monte. Io. Baptistae Montani... In primam fen libri primi canonis Avicennae explanatio, a Valentino Lublino collecta, Venetiis 1554 lub Io. Bapt. Montani Veronensis... In Primi Lib. Canonis Avicennae Primam Fen, profundissima explanatio Commentaria, Adiecto nuper Secundo, quod nunquam antea fucrat Typis excusum, De Membris Capite, Venetiis 1558.

${ }^{439}$ Giovanni Battista da Monte. Ioan. Baptistae Montani... In libros Galeni de arte curandi ad Glauconem explanationes (edytor Valentinus Lublinus, Walenty z Lublina, którego nazwisko pojawia się w dedykacji), Lugduni 1556 lub weneckie wydanie z 1554 r.

${ }^{440}$ Levinus Lemnius (Lievens Lemmens, Levinio Lennio) (1505-1568), niderlandzki lekarz i filozof. Wiele wydań, przykładowo: Leuini Lemnii... Occulta naturae miracula, ac varia rerum documenta, probabili ratione atque artifici coniectura duobus libris explicat..., Antverpiae 1561.

${ }^{441}$ Dzieła nie udało się zidentyfikować.

${ }^{442}$ Giovanni Battista da Monte. Io. Baptistae Montani Veronensis In nonum librum Rhasis ad Mansorem regem Arabum expositio. A Valentino Lublino Polono, medicis posteritatique eorum fideliter communicata, Venetiis 1554 lub Ioannis Baptistae Montani... In nonum librum Rhasis ad R. Almansorem lectiones primi anni publice professionis in Academia Patauina summa fide, atque diligente cura emendatae... à Ioanne Cratone..., Basileae, 1562.

${ }^{443}$ Gabrielle Falloppio. Gabrielis Falloppii medici Mutinensis Obseruationes anatomicae. Ad Petrum Mannam medicum Cremonensem..., Venetiis 1561 lub wydanie z 1562 r. (kolońskie, paryskie lub weneckie).

${ }^{444}$ Theophrastus (Theophrastus Eresius, Theophrasto, Theophrastos Eresios) (ok. 371-286 p.n.e.), grecki filozof, uczeń Arystotelesa. Prawdopodobnie: Theophrastou Peri phytōn historian: kai peri 
342 Nova co[n]stitutio Artis revellendi per vene section[em] Thadei Dunii no[n] ligata 445

343 Fragmenta Carminu[m] poeta[rum] no[n] ligata ${ }^{446}$

344 Themisti Philosophi oratio[ne]s $\mathrm{s}^{447}$

345 Praeparatio ad morte[m] Ludovici Beri ${ }^{448}$

$346 \mathrm{~S}[\mathrm{e}] \mathrm{c}[\mathrm{un}]$ dae partis Co[m]mentarior[um] De statu religionis in Regno Vngariae ${ }^{449}$

347 Practica reru[m] criminaliu[m] Jodoci Damuderii ${ }^{450}$

348 Ep[istu]lae duae Ministror[um] Tigurinoru[m] ad Ecclesias Polonicus ${ }^{451}$

349 Epithome Xenodochii Alberti Bassii ${ }^{452}$

350 Joachimi Camerarii Conversa ex Tucitidis Historia quaeda[m $]^{453}$

351 Actuarii de Vrinis ${ }^{454}$

352 Confessio fidei Polonic[orum] $]^{455}$

353 Gordini in libru[m] maedicinae $e^{456}$

Ite $[\mathrm{m}]$ in $16^{\circ}$

354 Apophtegmata Graeca Plutarchi ${ }^{457}$

355 Pindari Olimpia Graecolatina ${ }^{458}$

phytōn aitiōn, kai tina alla autou biblia periechōn tomos VI = Theophrasti Historiam de plantis, et De cavsis plantarvm, et qvosdam alios ipsivs libros continens tomvs VI, Venetiis 1552.

${ }_{445}$ Taddeo Duno (Thaddaeus Dunus Locarnensis) (1523-1613), szwajcarski lekarz, pisarz. Wiele wydań, przykładowo: Nova Constitvtio Artis Revellendi, Derivandi, Simplicitérq[ue] vacuandi per venae sectionem, vno quidem libro, eóque breui comprehensa, ... Thaddaeo Dvno Locarnense Medico authore, Zürich [ca. 1570].

${ }^{446}$ Dzieła nie udało się zidentyfikować. Zob. poz. 202/390.

${ }^{447}$ Themistius Euphrades (Themistius Sophista, Themistios) (ok. 317-388), grecki filozof, retor. Themistii Euphradae Philosophi Peripatetici Orationes octo elegantissimae, ac eruditione varia refertissimae. A Hieronymo Donzellino..., Basileae 1559.

${ }^{448}$ Ludwig Ber (Ludovicus Berus, Ludwig Berus, Ludwig Bär) (1479-1554), profesor teologii, rektor Uniwersytetu w Bazylei. Praeparatio salutaris ad mortem, ex Scriptura sacra, \& sanctis, doctis \& christianissimis doctoribus, a Ludovico Bero... conscripta, Antverpiae 1554.

${ }^{449}$ Dzieła nie udało się zidentyfikować.

${ }^{450}$ Joos de Damhouder (Iodocus Damhouderius) (1507-1581), niderlandzki prawnik. Wiele wydań, przykładowo Practica rerum criminalium, opus celebre \& elegans, atque adeo praetoribus, propraetoribus... Iodoco Damhouderio Brugensi, iureconsulto clarissimo autore..., Lugduni 1558.

${ }^{451}$ Dzieła nie udało się zidentyfikować, prawdopodobnie zaginione.

${ }^{452}$ Albert Bassaeus (Wojciech Basaeus, Albert z Szczebrzeszyna Rusak) (XVI w.), kanonik regularny szpitalników św. Ducha w Krakowie, pisarz. Epitome Xenodochii m. Alberti Bassaei Scebresinensis... siue capita qu[a]eda[m] ex Xenodochio seu libro de officio erga hospites, peregrinos, pauperes variasque miserabiles $p[e r]$ sonas $p$ [ro]pter reformandu[m] hospitalia edita..., Cracoviae 1570.

${ }^{453}$ Joachim Camerarius (Joachimus Camerarius Papebergensis, Joachim Camerarius der Ältere) (1500-1574), niemiecki teolog, filolog, humanista. Conversa Ex Thucydidis Historia Qvaedam In Latinvm sermonem, \& de autore illo, deque scriptis ipsius exposita, nec non explicata aliqua a Ioachimo Camerario Pabepergensi, Witebergae 1565.

${ }^{454}$ Joannes Actuarius. Wiele wydań, przykładowo: De urinis Actuarii Ioannis Zachariae filii, medici praestantissimi libri 7..., Basileae 1563.

${ }^{455}$ Dzieła nie udało się zidentyfikować.

${ }^{456}$ Dzieła nie udało się zidentyfikować.

${ }^{457}$ Plutarchus Chaeronensis. Przypuszczalnie: Apophtegmata Graeca regum \& ducum, philosophorum item, aliorumque quorundam ex Plutarcho \& Diogene Laertio..., [Genevae] 1568.

${ }^{458}$ Pindarus (Pindaros, Pindaro) (ok. 522-443 p.n.e.), grecki poeta. Wiele wydań, przykładowo: Pindari Olympia, Pythia, Nemea, Isthmia. Caeterorum octo lyricorum carmina, Alcaei, Sapphus, Ste- 
356 Nov[um] testam[en]tu[m] Theodori Beza ${ }^{459}$

357 Paraphrasis Psalmor[um] Georgii Bucani ${ }^{460}$

358 Apiani de Civilib[us] Romanor[um] bellis ${ }^{461}$

359 De co[m]pone[n]dis medicam[en]t[is] Fuxii ${ }^{462}$

360 Magiae naturalis ${ }^{463}$

361 Macaronicor[um] poema ${ }^{464}$

362 Herodiani Historiae Graece ${ }^{465}$

363 Angerii ferreri de Somnis liber ${ }^{466}$

364 Institutionu[m] Anathomicar[um] libri qu[attu]or ${ }^{467}$

365 Adagia Erasmi ${ }^{468}$

366 Terra praepostica Galeni ${ }^{469}$

367 De Affector[um] locor[um] notitia Galeni ${ }^{470}$

368 Institutiones Anathomicae s[e]c[un]d[u]m Galeniu[m] $]^{471}$

369 Coelu[m] Philosophorum Phillipii Vlstadii ${ }^{472}$

sichori, Ibyci, Anacreontis, Bacchylidis, Simonidis, Alcmanis, nonnulla etiam aliorum. Omnia Graecè \& Latinè..., Antverpiae 1567.

${ }^{459}$ Theodore de Beze. Wiele wydań, przykładowo: Tēs Kainēs Diathēkēs hapanta = Novum Jesu Christi Domini nostri Testamentum ..., Tiguri 1559.

${ }^{460}$ George Buchanan (Georgius Buchananus Scotus) (1506-1582), szkocki humanista, filozof, historyk. Wiele wydań, przykładowo: Psalmorum Davidis paraphrasis poetica, nunc primum edita, authore Georgio Buchanano Scoto..., Argentorati 1566.

${ }^{461}$ Appianus Alexandrinus (95-165). Prawdopodobnie: De civilibus Romanorum bellis historiae Appiani Alexandrini De civilibus Romanorum bellis historiarum libri quinque..., Moguntiae 1529.

${ }^{462}$ Leonhart Fuchs. Prawdopodobnie: De componendorum miscendorumque medicamentorum ratione libri quatuor, iam recens recogniti, Leonharto Fuchsio autore..., Lugduni 1556.

${ }^{463}$ Giambattista della Porta (Giovanni Battista della Porta, Joannes Baptista Porta) (1535-1615), włoski humanista, autor traktatów z różnych dziedzin: filozofii, przyrody, fizyki, chemii. Wiele wydań, przykładowo: Magiae naturalis, siue De miraculis rerum naturalium libri 4. Io. Baptista Porta Neapolitano auctore, Antverpiae 1560.

${ }^{464}$ Prawdopodobnie: Macaronicorum poema. Baldus. Zanitonella. Moschaea. Epigrammata. Tam sibi dissimilis, tamque alter habetur ab illo Merlino, ut primum nesciat autor opus..., [Teofilo Folengo], Venetiis 1555.

${ }^{465}$ Herodianus Syrus (Herodianus historicus, Herodianos) (ok. 170-255), grecki historyk. Wiele wydań, przykładowo: Herodianou Historion biblia 8. Herodiani De imperatorum Romanorum praeclare gestis lib. 8. Graeci \& Latini..., Basileae 1549.

${ }^{466}$ Auger Ferrier (Augerius Ferrerius Tolosatis) (1513-1588), francuski lekarz, astrolog, matematyk. Augerii Ferrerii Tolosatis medici Liber de somniis. Hippocratis De insomniis liber. Galeni Liber de insomniis. Synesii Liber de somniis, Lugduni 1549.

${ }^{467}$ Dzieła nie udało się zidentyfikować.

${ }^{468}$ Erasmus Rotterdamus. Wiele wydań, przykładowo: Adagiorum D. Erasmi Roterodami epitome. Ex nouissima chiliadum recognitione excerpta, Lugduni 1553.

${ }^{469}$ Dzieła nie udało się zidentyfikować.

${ }^{470}$ Claudius Galenus. Wiele wydań, przykładowo: Claudii Galeni de locorum affectorum notitia libri sex, Gulielmo Copo Basiliensi interprete, ..., Lugduni 1549.

${ }^{471}$ Claudius Galenus. Wiele wydań, przykładowo: Institutionum Anatomicarum Secundum Galeni sententiam ad candidatos Medicinae Libri Quatuor, per Ioannem Guinterium Andernacum Medicum, Patavii 1550.

472 Philipp Ulstad (Philipp Ulstadt, Philipp Ulsted, Philippus Olstadius) (XVI w.), niemiecki lekarz. Wiele wydań, przykładowo: Coelum philosophorum, seu Liber de secretis naturae, per Philippum Vlstadium exvariis autoribus accuratè selectus, variisque figuris illustratus..., Lugduni 1557. 
370 Hieronimi Fracastarii, de Simpathia et antipathia reru[m] $]^{473}$

371 Hieremiae Triveri in Galeni libros de Temperam[en]tis peravitis ${ }^{474}$

372 Heroica Simbola Claudiii ${ }^{475}$

373 Dispensatoriu[m] Valeri Codri ${ }^{476}$

Item In Cistella in octavo

374 Harmonia Calvini4 ${ }^{477}$

375 Rondelicii methodus Cura[n]dor[um] morbor[um] $]^{478}$

376 Diogenes Laertius de Vitis Philosophor[um] $]^{479}$

377 De activa maedicina Hieronimi Montui ${ }^{480}$

378 Donati ab alto mari ars medica ${ }^{481}$

379 Holerii de morbor[um] curatio[n] $\mathrm{e}^{482}$

380 De infantiu[m] morbis Sebastiani Austeriii ${ }^{483}$

${ }^{473}$ Girolamo Fracastoro. Wiele wydań, przykładowo: Hieronymi Fracastorii Veron. Liber vnus, de sympathia \& antipathia rerum. Item, De contagione, \& contagiosis morbis, \& eorum curatione, lib. 3, Lugduni 1554.

${ }^{474}$ Hieremias Thriverus (Jeremie de Dryvere, Jeremias Thriverus Brachelius) (1504-1554), niderlandzki lekarz, fizyk. Hieremiae Thriveri Brachelii novi et integri Commentarii in omnes Galeni libros de Temperamentis, Lugduni 1547 lub wcześniejsze wydanie z 1535 r.

${ }^{475}$ Claude Paradin (Claudius Paradinus) (ok. 1510-1573), francuski pisarz, historyk. Wiele wydań, przykładowo: Symbola heroica M. Claudii Paradini, Belliiocensis canonici, et D. Gabrielis Symeonis..., Antverpiae 1567.

${ }^{476}$ Valerius Cordus (Valerio Cordo) (1515-1544), niemiecki lekarz, farmakolog, botanik. Wiele wydań, przykładowo: Dispensatorium, hoc est, pharmacorum conficiendorum ratio. Valerio Cordo authore..., Venetiis 1556.

477 Jean Calvin. Wiele wydań, przykładowo: Harmonia ex tribus evangelistis composita Matthaeo, Marco, et Luca, adjuncto seorsum Johanne, quod pauca cum aliis communia habeat cum Johannis Calvini commentariis, [Genève] 1563.

${ }^{478}$ Guillaume Rondelet (Gulielmus Rondalitius) (1507-1566), francuski lekarz, przyrodnik. Wiele wydań, przykładowo: Gulielmi Rondeletii doctoris medici, ... Methodus curandorum omnium morborum corporis humani in tres libros distincta..., Parisiis [1563].

${ }^{479}$ Diogenes Laertius (Diogen Laertsii, Diogene Laerzio, Diogenes Philosophus) (III w.), grecki historyk filozofii. Wiele wydań, przykładowo: Diogenis Laertii clariss. historici De vitis ac moribus priscorum philosophorum libri decem..., Coloniae 1542.

${ }^{480}$ Jerome de Monteux. De actiua medicinae scientia commentarii duo. Quorum primus de salubritate non modò tuendae sanitatis, uerumetiam producendae ad multos annos uitae rationem modumque docet. Alter uero uniuersales, qui ad morborum curationes pertinent, canones explanat. Autore D. Hieromymo Montuo..., Lugduni 1557. W oryginale zapis sugeruje dwa dzieła.

${ }^{481}$ Donato Antonio Altomare (Donatus Antonius ab Altomare Neapolitanus, Donato Antonio d' Altomare) (1520-1566), włoski lekarz, farmakolog, filozof. Wiele wydań, przykładowo: Donati Antonii ab Altomari... De medendis humani corporis malis: ars medica ..., Lugduni 1563.

${ }^{482}$ Jacques Houllier (Iacobus Hollerius, Giacomo Hollerio) (15??-1562), francuski lekarz. Wiele wydań, przykładowo: Iacobi Hollerii Stempani medici Parisiensis celeberrimi De morborum curatione. Eiusdem de febribus [de] peste de remedia kata topous in Galeni libros [de] materia chirurgica, Paris 1565 .

${ }^{483}$ Sebastianus Austrius (Sebastianus Rubeaquensis, Sebastien Ostericher) (? - zm. 1540), lekarz. De Infantivm Sive Pverorvm, Morborum et symptomatum, dignotione, tum curatione Liber: ex Graecorum, Latinorum et Arabum placitis, atq[ue] scitis diligenter erutus, ..., à Sebastiano Austrio Rubeaquensi, Basileae 1540. 
381 Explanatio in decalogu[m] Volffga[n]gi Musculi484

382 De cura[n]di ratio[ne] Fuxii ${ }^{485}$

383 In Gatinaria de morbor[um] Curatio[n] $\mathrm{e}^{486}$

\section{Księgozbiór Stanisława Różanki według inwentarza z roku 1583 (Advocatialia Cracoviensia rkps 202)}

$\begin{array}{ll} & \text { Libri in folio } \\ 1 & \text { Volateranus in Gnesneri duo thomi }{ }^{487} \\ 2 & \text { Muteol herbarius } \\ 3 & \text { Anatomia Vesanii4 }^{488} \\ 4 & \text { Martir in Samuelem } \\ 5 & \text { Isaaci opera } \\ 6 & \text { Herodotus cum Appiano } \\ 7 & \text { Hÿrurgia } \\ 8 & \text { Statut laczÿnski }{ }^{490} \\ 9 & \text { Dionis historia } \\ 10 & \text { Gentilis de febribus ÿ Herculanus } \\ 11 & \text { Thadaeus Florentinus ÿ Herculanus } \\ 12 & \text { Praktika Sabonarolae de Febribus } \\ 13 & \text { Praktika maior eiusdem } \\ 14 & \text { Atheneus et Niphus } \\ 15 & \text { Plutarchus } \\ 16 & \text { Consilia Montani } \\ 17 & \text { Tabulae in medicinam Zwigneri } \\ 18 & \text { Chronika Othonis } \\ 19 & \text { Galleni o[mn]es thomi grecae } \\ \end{array}$

${ }^{484}$ Wolfgang Musculus (Vuolffgangus Musculus, Wolfgang Moesel) (1497-1563), niemiecki teolog luterański, filolog. In Decalogum Praeceptorum Dei Explanatio, Per Vuolfgangum Musculum iam recens edita, Basileae 1553.

${ }^{485}$ Leonhart Fuchs. Wiele wydań, przykładowo: Leonharti Fvchsii Ad Qvinqve Priores Svos Libros De Cvrandi Ratione, Seu de sanandis totius humani corporis eiusdémque partium tam internis quàm externis malis, ..., Lugduni 1553.

${ }^{486}$ Marco Gatinaria (Marcus Gatinara) (1442-1496), włoski lekarz, filozof. Identyfikacja niepewna. Być może chodzi o dzieło, którego autorem jest Jacques Dubois: Morborum internorum prope omnium curatio, certa methodo comprehensa, ex Galeno praecipuè, \& Marco Gattinaria, per Iacobum Syluium... selecta... (wiele wydań, przykładowo Parisiis 1554).

${ }^{487}$ Zob. poz. $184 / 8$ ?

${ }^{488}$ Zob. poz. $184 / 34$ i $184 / 89$.

${ }^{489}$ Zob. poz. $184 / 87$.

${ }^{490}$ Zob. poz. $184 / 45$, 184/85 i 184/102 oraz 202/87 oraz 202/118.

${ }^{491}$ Zob. poz. $184 / 328$.

${ }^{492}$ Zob. poz. $184 / 80$.

${ }^{493}$ Zob. poz. $184 / 26$ i $184 / 354$.

${ }^{494}$ Zob. poz. $184 / 53$.

${ }^{495}$ Zob. poz. 184/78.

${ }^{496}$ Zob. poz. 184/72. 
20 Consiliator $^{497}$

21 Herculanus de Febribus et in Rasium

22 Enetha

23 Anrieca

24 Philoponus in Phisicam ÿ Alexander de anima

25 Aristotelis opera

26 Imagines variae ${ }^{498}$

27 Ius Civile ${ }^{499}$

28 Chirurgia Guidonis ${ }^{500}$

29 Victorus in Rethorica[m]

30 Simplicius in librum de caelo ${ }^{501}$

31 Thomas Aquinas in Aristotelis Politica ${ }^{502}$

32 Fasciculus rerum ${ }^{503}$

33 Hÿpocrates graece

34 Vicomercatus in Phisica $[\mathrm{m}]^{504}$

35 Tucidides graece ${ }^{505}$

36 Linius

37 Trulianus graece

38 Aetius graece ${ }^{506}$

39 Theodori gram $[\mathrm{m}]$ atica graece y Priscianus

40 Chronographia Sculteti ${ }^{507}$

41 Fasciculus medicinae ${ }^{508}$

42 Expostiones Thadaei

43 Thadeus in Hÿpocrate ${ }^{509}$

44 Index Brasavolae in Galenum

45 Galleni opera omnia

46 Plinnius ${ }^{510}$

47 Grammaticus Ioannes in Phisicam

48 Robotellus in Aristotelem de arte Poetica et in Horatium de eadem ${ }^{511}$

49 Philoponus in degeneratione animalium ${ }^{512}$

50 Imagines ex Vesalio

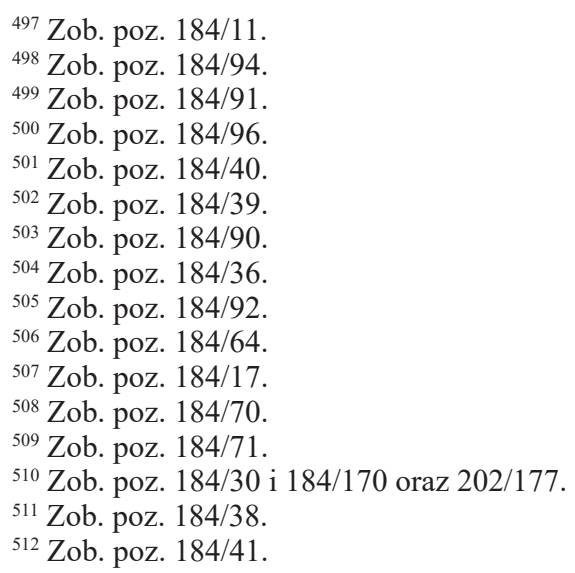


51 Tucidides latine ${ }^{513}$

52 Heidanom $[\mathrm{u}] \mathrm{s}$

53 Lexicon graeco latinum ${ }^{514}$

54 Vicomercatus in Metheora

55 Serasio

56 Albohuse

57 Averoes in Arystotelem ${ }^{515}$

58 Luminare ${ }^{516}$

59 Geographia Ptolomoei ${ }^{517}$

60 Polus de ecclesiastica defensione ${ }^{518}$

61 De morbo Gallico ${ }^{519}$

62 Testamentum Gezae ${ }^{520}$

63 Dictionarium graecum ${ }^{521}$

64 Amonius in Aristotelem graecae ${ }^{522}$

65 Ioannes Cathuenzenus

66 Philoponus in posteriora ${ }^{523}$

67 Martir in librum Judicum ${ }^{524}$

68 Klinch $^{525}$

69 Aetius latine ${ }^{526}$

70 Nicolai Peroti, cornu copiae ${ }^{527}$

71 Montagnare consilia ${ }^{528}$

72 Mesue $^{529}$

73 Ignatius in dioscoriden ${ }^{530}$

74 Grammaticus graece

75 Discorides latine.

76 Chirurgia Ioannis de Vigo ${ }^{531}$

77 Calumnus in prophetas

78 Medici antiqui ${ }^{532}$

\footnotetext{
${ }^{513}$ Zob. poz. $184 / 22$.

${ }^{514}$ Zob. poz. $184 / 25$.

${ }^{515}$ Zob. poz. $184 / 69$.

${ }^{516}$ Zob. poz. $184 / 76$.

${ }^{517}$ Zob. poz. $184 / 18$.

${ }^{518}$ Zob. poz. 184/19.

${ }^{519}$ Zob. poz. 184/99.

${ }^{520}$ Zob. poz. 184/356.

${ }^{521}$ Zob. poz. 184/98.

${ }^{522}$ Zob. poz. $184 / 33$.

${ }^{523}$ Zob. poz. $184 / 28$.

${ }^{524}$ Zob. poz. 184/93.

${ }^{525}$ Zob. poz. $184 / 15$ ?

${ }^{526}$ Zob. poz. $184 / 48$.

${ }^{527}$ Zob. poz. 184/16.

${ }^{528}$ Zob. poz. $184 / 23$.

${ }^{529}$ Zob. poz. $184 / 58$.

${ }^{530}$ Zob. poz. $184 / 59$.

${ }^{531}$ Zob. poz. 184/62.

${ }^{532}$ Zob. poz. 184/61.
} 
79 Traegediae Senecae ${ }^{533}$

80 Persius cum Capella

81 Eustratius in aethica Aristotelis graece ${ }^{534}$

82 Fincanellus

83 O pokucie ${ }^{535}$

84 Adagia Erasmi ${ }^{536}$

85 Fricius de Repub.[lica] et alia eiusdem ${ }^{537}$

86 Sellius

87 Statut starÿ 338

88 Simplicis in $\mathrm{p}[\mathrm{rae}]$ dicamenta Aristotelis et Phisica ${ }^{539}$

89 Argenterius de morbis, et nigrasia de tumoribus et Sÿlvii Tabulae ${ }^{540}$

90 Imagines partium humani corporis ${ }^{541}$

91 Mathioli Epistolae ${ }^{542}$

92 Eusebius graece ${ }^{543}$

93 Aristotelis opera graece

94 Ciniatius $^{544}$

95 Tabulae patrium Oratoriarum

96 Olimpiodorus in meteora

97 Consilia Godoe ${ }^{545}$

98 Aristoteles

99 Livius $^{546}$

In quatro

100 Decretales tonitres

101 Iachinus in Rasium et Phalopius de purgantibus ${ }^{547}$

102 Biezius de Theorgica medicinae

103 De captivitate Babilonica, Luterus ${ }^{548}$

104 Praxis rerum civilium ${ }^{549}$

${ }^{533}$ Zob. poz. $184 / 75$.

534 Zob. poz. $184 / 7$.

${ }^{535}$ Zob. poz. 184/13.

${ }^{536}$ Zob. poz. $184 / 9$ i $184 / 365$ oraz 202/372.

${ }^{537}$ Zob. poz. $184 / 79$.

${ }^{538}$ Zob. poz. 184/45, 184/85 i 184/102 oraz 202/8 oraz 202/118.

${ }^{539}$ Zob. poz. $184 / 44$.

${ }^{540}$ Zob. poz. $184 / 3$.

${ }^{541}$ Zob. poz. $184 / 56$.

${ }^{542}$ Zob. poz. $184 / 57$.

${ }^{543}$ Zob. poz. $184 / 2$.

${ }^{544}$ Dzieła nie udało się zindetyfikować. Być może autorem był Jacques Cujas (Iacobus Cuiacius, Jacobus Cujacus) (1522-1590), francuski prawnik, humanista.

545 Zob. poz. 184/101.

${ }^{546}$ Zob. poz. $184 / 97$.

${ }^{547}$ Tak zapisano w rękopisie. Prawdopodobnie chodzi o dwa dzieła. Iachinus in Rasium zob. poz. 184/113, Phalopius de purgantibus zob. poz. 184/283.

${ }_{548}$ Zob. poz. 184/125.

${ }^{549}$ Zob. poz. 184/143. 
105 Sprawa rÿccerska ${ }^{550}$

106 Logica Aristotelis ${ }^{551}$

107 Aristitelis Politica ${ }^{552}$

108 Trapezuncii Rhetorica ${ }^{553}$

109 Hodeporicon Constantinopolshie ${ }^{554}$

110 Epistolae de stirpibus ${ }^{555}$

111 Sacrabusti sphaera ${ }^{556}$

112 Collatio Evangelistarum ${ }^{557}$

113 Methodus curandi Domininici Leoni ${ }^{558}$

114 Amatus Lusitanus, in dioscorden ${ }^{59}$

115 Catho de re rustica et alii ${ }^{560}$

116 Acta martirum ${ }^{561}$

117 Phalopi opuscula

118 Repertorium statutorum ${ }^{562}$

119 Manus scriptus liber ${ }^{563}$

120 Italica historia ${ }^{564}$

121 Phracastorius $^{565}$

122 Rivius de Dei Consilio 566

123 Stancarus de Trinitate ${ }^{567}$

124 Psalterium Davidis

125 Hÿponimata in Strigelij Testamentus ${ }^{568}$

126 Actuarius $^{569}$

127 Aristotelis, quaedam opera graece

128 Pauli Scalilchii miscelanea

129 Halosis Febrium $^{570}$

${ }^{550}$ Marcin Bielski (Martinus Bielscius, Marcin Wolski) (ok. 1500-1575), humanista, kronikarz, poeta. Sprawa rycerska wedtug postepku y zachowania starego obyczaiu Rzymskiego, Greckiego, Macedońskiego y innych narodow pierwszego y ninieyszego wieku, tak Pogańska iako y Krześciańska, z rozmaitych ksiag wypisana ku czytaniu y nauce ludziom rycerskim pożyteczna..., Kraków 1569.

${ }^{551}$ Zob. poz. 184/128.

${ }^{552}$ Zob. poz. $184 / 240$ oraz $202 / 229$.

${ }^{553}$ Zob. poz. 184/134.

${ }^{554}$ Zob. poz. $184 / 136$.

${ }_{555}^{55}$ Zob. poz. $184 / 139$.

${ }^{556}$ Zob. poz. $184 / 132$ oraz 202/250.

${ }^{557}$ Zob. poz. $184 / 110$.

${ }^{558}$ Zob. poz. $184 / 109$.

${ }^{559}$ Zob. poz. $184 / 138$.

${ }^{560}$ Zob. poz. $184 / 116$.

${ }^{561}$ Zob. poz. $184 / 152$ ?

${ }^{562}$ Zob. poz. $184 / 45,184 / 85$ i $184 / 102$ oraz $202 / 8$ oraz $202 / 87$.

${ }^{563}$ Zob. poz. $184 / 91$ ?

${ }^{564}$ Zob. poz. $184 / 117$.

${ }^{565}$ Zob. poz. $184 / 121$

${ }^{566}$ Zob. poz. $184 / 127$.

${ }^{567}$ Zob. poz. $184 / 120$.

${ }^{568}$ Zob. poz. $184 / 104$.

${ }^{569}$ Zob. poz. 184/140 lub 184/149 lub 184/351.

${ }^{570}$ Zob. poz. 184/107. 
130 Aristotelis Phisica latine ${ }^{571}$

131 Descriptio Italiae Italice ${ }^{572}$

132 Actomarus de Febribus

133 Iulius Delphinus, in artem Galleni ${ }^{573}$

134 Almanach Pitati ${ }^{574}$

135 Scriptus liber

136 Historiae Italicae

137 Hÿpocrates, latine

138 Elianus ${ }^{575}$

139 De clandestinis coniugiis

140 Bocatius Italice ${ }^{576}$

141 Exercitium Logicae ${ }^{577}$

142 Fricii opuscula ${ }^{578}$

143 De aqua Ungariae ${ }^{579}$

144 Liber Italicus de domo [...] ]etomeno

145 Index rerum omnium

146 Liber scriptus in pargameno

147 Aristotelis Phisica

148 Tabulae Astronomicae Schoneri

149 Pindarus graece ${ }^{580}$

150 Actuarius $^{581}$

151 Questio de Flebotomiis ${ }^{582}$

152 Faparella in Hÿpocratem

153 Gatinaria $^{583}$

154 Carolis Sigonii de antique Jure ${ }^{584}$ In octavo

155 Aristotelis graece Rhetorica

156 Ad Samuelem Episcopum Crac.[oviensem] ${ }^{585}$

157 Laurentius Valla ${ }^{586}$

${ }^{571}$ Zob. poz. 184/103.

${ }^{572}$ Zob. poz. 184/108.

${ }^{573}$ Zob. poz. $184 / 141$.

${ }^{574}$ Zob. poz. $184 / 124$.

${ }^{575}$ Zob. poz. 184/133.

${ }^{576}$ Zob. poz. $184 / 130$ oraz 202/364 i 202/393.

${ }^{577}$ Zob. poz. $184 / 111$.

${ }^{578}$ Zob. poz. $184 / 115$.

${ }^{579}$ Zob. poz. $184 / 114$.

${ }^{580}$ Zob. poz. $184 / 355$.

${ }^{581}$ Zob. poz. 184/140 lub 184/149 lub 184/351.

${ }^{582}$ Zob. poz. $184 / 151$.

${ }^{583}$ Zob. poz. 184/383.

${ }^{584}$ Carlo Sigonio (Carolus Sigonius) (ok. 1520-1584), włoski humanista, historyk, filolog. Wiele wydań, przykładowo: Caroli Sigonii De antiquo iure Italiae libri 3, ad Senatum Populumq. Romanum, Venetiis 1562.

${ }^{585}$ Zob. poz. $184 / 238$.

${ }^{586}$ Zob. poz. 184/193. 
158 Fuxius de curandi ratione ${ }^{587}$

159 Budeus de asse ${ }^{588}$

160 Aristotelis nethra graece

161 Pausanias de Graecia ${ }^{589}$

162 Nonus de curatione morborum ${ }^{590}$

163 Fuxii institutiones medicinae ${ }^{591}$

164 Conciliationes scripturae Altamerus ${ }^{592}$

165 Athanasis de S.[ancta] Trinitate ${ }^{593}$

166 Aggrippa de occulta Philosphia ${ }^{594}$

167 Gallenus in Hypocratem de humoribus ${ }^{595}$

168 Xenophontis opera graece $\mathrm{e}^{596}$

169 Opera Ciceronis ${ }^{597}$

170 Topograqphia Romae ${ }^{598}$

171 Argentelius de Consultationibus mediciis ${ }^{599}$

172 Grammatica Clenardi ${ }^{600}$

173 Rosarium Trocedophÿ ${ }^{601}$

174 Senecae Hercules ${ }^{602}$

175 Isocrates graecae ${ }^{603}$

176 Loci communes Manliii ${ }^{604}$

177 Plinii opera $^{605}$

178 Musculus in decalogum ${ }^{606}$

179 Ars Alchimica Stuctii

180 Stanislaus Grzepsius ${ }^{607}$

181 De matrimonio Rotherodamus ${ }^{608}$

182 De vulneribus sclopetariorum

${ }^{587}$ Zob. poz. 184/382.

${ }^{588}$ Zob. poz. 184/165.

589 Zob. poz. 184/192.

${ }^{590}$ Zob. poz. 184/189.

${ }^{591}$ Zob. poz. 184/325.

592 Zob. poz. 184/199.

${ }^{593}$ Zob. poz. 184/157.

${ }^{594}$ Zob. poz. 184/160.

595 Zob. poz. 184/166.

${ }^{596}$ Zob. poz. 184/208.

${ }^{597}$ Zob. poz. 184/168.

${ }^{598}$ Zob. poz. 184/214.

${ }^{599}$ Zob. poz. 184/306.

${ }^{600}$ Zob. poz. $184 / 156$ oraz 202/206.

${ }^{601}$ Zob. poz. 184/158.

${ }^{602}$ Zob. poz. $184 / 196$.

${ }^{603}$ Zob. poz. $184 / 197$.

${ }^{604}$ Zob. poz. 184/163.

${ }^{605}$ Zob. poz. $184 / 30$ i $184 / 170$ oraz 202/46.

${ }^{606}$ Zob. poz. 184/381.

${ }^{607}$ Zob. poz. $184 / 229$.

${ }^{608}$ Zob. poz. 184/188. 
183 Maritius de Scholis ${ }^{609}$

184 Morte Encomium Rotherodami ${ }^{610}$

185 Rotherodami de recta $\mathrm{p}\left[\right.$ ro]nuntiatione ${ }^{611}$

186 Herbesti Arithmetica

187 Martius de lege spirituali ${ }^{612}$

188 De morborum curatione

189 Patricii oratio ${ }^{613}$

190 Actuarius de medicamentis ${ }^{614}$

191 Wÿznanie wiarÿ Orzechowskie $[\mathrm{g}] \mathrm{o}^{615}$

192 Psalterium Davidis

193 Ciceronis volumen secund[us]

194 Calvinus in Ezechielem ${ }^{616}$

195 Ioannis Baptistae in artem Galleni expla[nation] es $^{617}$

196 Quintilianus ${ }^{618}$

197 Ciceronis epistolae familiares

198 Rhetoricor[um] liber Ciceron.[is]

199 Euperistia Dioscoridis ${ }^{619}$

200 Grammatica Urbani Bolsani

201 Petri Andreae apologia con[tra] Amathum ${ }^{620}$

202 Viaticum novum de morborum occasione ${ }^{621}$

203 Casparis Wolfÿ ${ }^{622}$

204 Ioannis Baptistae in novum librum phrasis

205 Aristotelis et Theophrasti Historiae ${ }^{623}$

206 Clenardi Grammatica ${ }^{624}$

207 Constantini Cesaris de agricultura lib. $20^{625}$

208 De gemmis Erasmi stellae ${ }^{626}$

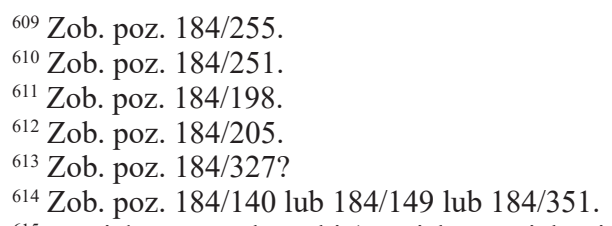

${ }^{615}$ Stanisław Orzechowski (Stanislaus Orichovius Ruthenus, Stanislaus Orichovius Okszius, Stanislaus Orichovius Polonius) (1513-1566), ksiądz katolicki, pisarz polityczny i religijny. Wyznánie wiáry Stánisłáwá Orzechowskiego ktore czynit w Piotrkowie ná Synodzie słożonym Przez iego Miłość Ksyędza Arcybiskupá Mikołáiá Dziergowskiego, roku Pańskiego, 1552. A potym ná drugim Synodzie Warszáwskim, potwierdzone y wydáne Roku Bożego 1561, b.m.w. 1562.

${ }^{616}$ Zob. poz. 184/159.

${ }^{617}$ Zob. poz. $184 / 330$ oraz $202 / 241$.

${ }^{618}$ Zob. poz. $184 / 176$.

${ }^{619}$ Zob. poz. 184/167.

${ }^{620}$ Zob. poz. $184 / 316$.

${ }^{621}$ Zob. poz. $184 / 270$.

${ }^{622}$ Prawdopodobnie poz. 202 i 203 to jedno dzieło. Zob. poz. 184/270 oraz 202/202.

${ }^{623}$ Zob. poz. $184 / 177$.

${ }^{624}$ Zob. poz. $184 / 156$ oraz $202 / 172$.

${ }^{625}$ Zob. poz. 184/201.

${ }^{626}$ Zob. poz. 184/275. 
209 Le anthahita di Roma ${ }^{627}$

210 Pauli Aeginethae medic. Opera ${ }^{628}$

211 Epithome Chrisostomi [Chrysostomi] Janelli Canopuli [Canopus]

212 Simeonis Setti Syntagma ${ }^{629}$

213 De fossilibus Conradi Gesneri ${ }^{630}$

214 Anthonii Musae Brasavoli examen $[\ldots]^{631}$

215 Ioannis Baccanelÿ de curandis morbis ${ }^{632}$

216 Discordis libri octo

217 Erasmi Roterodami de Ep[isto]lis conscriben.[dis] ${ }^{633}$

218 Petri Monsellani in quintiliani Retoricas ${ }^{634}$

219 Scholia Joannis agricolae ${ }^{635}$

220 Historiae di Nic[co]lo Machiavelli ${ }^{636}$

221 Enchiridion milit[is] christiani Erasmi ${ }^{637}$

222 Rethorica ad Herennium ${ }^{638}$

223 Cathechismus Tridentinus

224 Hieronimi Cardani de Subtilitate ${ }^{639}$

225 Aureoli Paracelsi libri quinque de causis ${ }^{640}$

226 Conversa historia ex Tucidide ${ }^{641}$

227 Franciscus Valeriola ${ }^{642}$

228 Lossius in grammaticam Philippi ${ }^{643}$

229 Aristotelis Politica ${ }^{644}$

230 Dioscorti di Nicola Machievelli sup[er] Livium ${ }^{645}$

231 Ioannis Fornetii Ambiani medicina ${ }^{646}$

232 Io[ann]is Baptistae in tertium primi epidomor[um] sectinios ${ }^{647}$

233 Theoriae Planetarum ${ }^{648}$

${ }^{627}$ Zob. poz. 184/265.

${ }^{628}$ Zob. poz. 184/293.

${ }^{629}$ Zob. poz. 184/292.

${ }^{630}$ Zob. poz. $184 / 164$ i $184 / 289$ oraz 202/267.

${ }^{631}$ Zob. poz. 184/331.

${ }^{632}$ Zob. poz. $184 / 333$.

${ }^{633}$ Zob. poz. 184/236.

${ }^{634}$ Zob. poz. $184 / 237$.

${ }^{635}$ Zob. poz. 184/319.

${ }^{636}$ Zob. poz. $184 / 172$.

${ }^{637}$ Zob. poz. $184 / 318$.

${ }^{638}$ Zob. poz. 184/232.

${ }^{639}$ Zob. poz. 184/296.

${ }^{640}$ Zob. poz. $184 / 290$.

${ }^{641}$ Zob. poz. 184/350.

${ }^{642}$ Zob. poz. 184/334.

${ }^{643}$ Lucas Lossius (Lukas Loss, Luca Lossio) (1508-1582), pedagog, teolog protestancki. Wiele wydań, przykładowo: Lucae Lossi Annotationes in grammaticam D. Philippi Melanth. Latinam..., Francofurti 1565.

${ }^{644}$ Zob. poz. $184 / 240$ oraz 202/107.

${ }^{645}$ Zob. poz. $184 / 171$.

${ }^{646}$ Zob. poz. $184 / 332$.

${ }^{647}$ Zob. poz. $184 / 284$.

${ }^{648}$ Zob. poz. 184/200. 
234 Amati Lusitani centuria prima ${ }^{649}$

235 Donati Acciaroli in Politicor[um] $]^{650}$

236 Anthonii Musae examen sÿruporum ${ }^{651}$

237 Hieronimi Cardani ${ }^{652}$

238 Petri Vireti de co[m]municatione fidelium ${ }^{653}$

239 Bassiani Landi opuscula ${ }^{654}$

240 Pharrago lucis

241 Io[ann]is Baptistae in lib.[rum] Galleni de aerte curan[di] ${ }^{655}$

242 Erasmi de ratione concionandi ${ }^{656}$

243 Varia opera vel prologomena

244 Ioannis Hartungi ${ }^{657}$

245 Gabrielis Falopii anatomor.[um] operationis ${ }^{658}$

246 Grammatica Philippi ${ }^{659}$

247 Joannis Manardi ep[isto]lae medicinalium ${ }^{660}$

248 Xenophontis opera omnia

249 Lucianus Samosatensis ${ }^{661}$

250 Ioannis de Sacro busto Sphaera ${ }^{662}$

251 Aristotelis Poetica latine

252 Ioannis Calvinii in librum Iosue ${ }^{663}$

253 De aeterno Dei filio losii Simleri ${ }^{664}$

254 Aeschilii Tragediae septem ${ }^{665}$

255 Medicinae Partentii Giovani

256 Marinello

257 Marsilius Ficinus ${ }^{666}$

258 Do.[mini] Iasonis de cerebri morbis ${ }^{667}$

259 Mathematica

260 Andreae Vessalii, chÿrurgia magna ${ }^{668}$

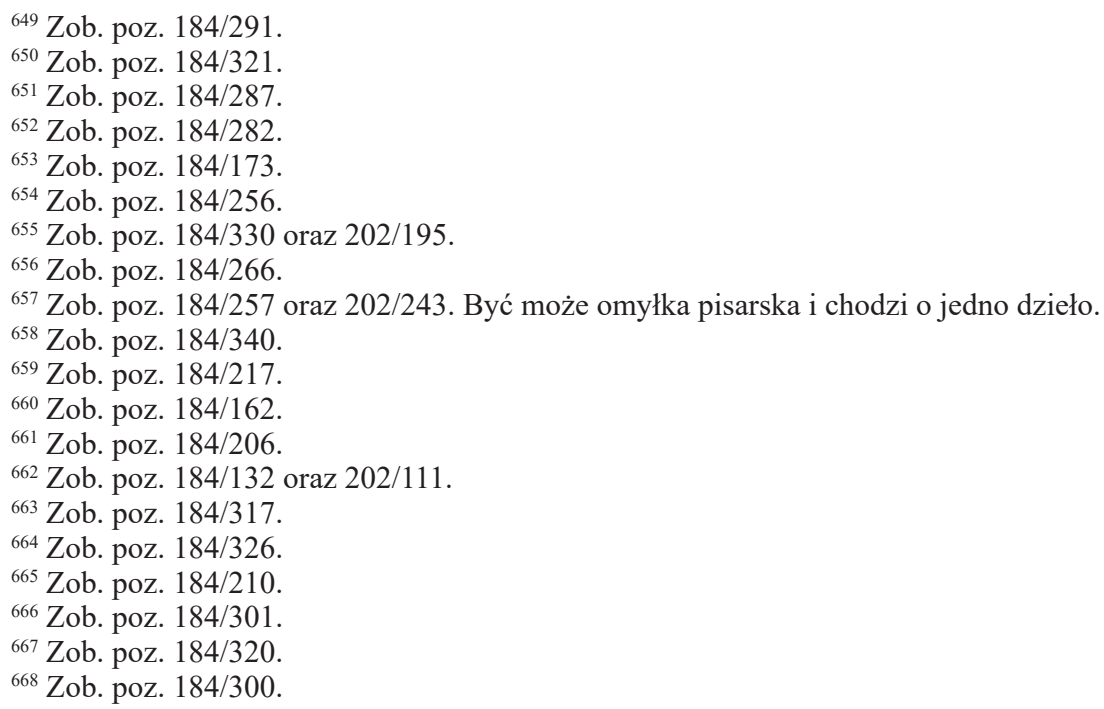


261 Philostrati Historiae ${ }^{669}$

262 Colloquia Erasmi Rotherodami ${ }^{670}$

263 Paraphrases Philosophiae ${ }^{671}$

264 Morbi Gallici curan[di] ratio ${ }^{672}$

265 Petri Carolini de uno vero Deo673

266 Io[ann]is Baptistae in Aphorismo Hÿpocratis ${ }^{674}$

267 De omni fossilium genere ${ }^{675}$

268 Nicolai Birsii in artem medica[m] Galleni ${ }^{676}$

269 Contradictiones Nicolai Rosarii

270 Valentini Poloni ${ }^{677}$

271 Ioannis Baptistae in primam fen ${ }^{678}$

272 Holerii de morborum curatione ${ }^{679}$

273 Io[ann]is Baptistae in quarta[m] feri ${ }^{680}$

274 Ioannis Strurii de periodis /poprawiano/

275 Garciae Lopii de varia rei medicinae lectione ${ }^{681}$

276 Loci p[rae]cipui Theologiae Philippi ${ }^{682}$

277 Casparis Contareni de elementis ${ }^{683}$

278 Plinii Epistolae ${ }^{684}$

279 Aulus $^{685}$

280 Stancarus $^{686}$

281 Nicolai Borbonii ungar[um] $]^{687}$

282 Linguae Latinae exercitatio ${ }^{688}$

283 Ioannie Ravisii Textoris epiteta ${ }^{689}$

284 Heres Bacchi de re rustica ${ }^{690}$

285 Index in Plinii Historiar[um] libros ${ }^{691}$

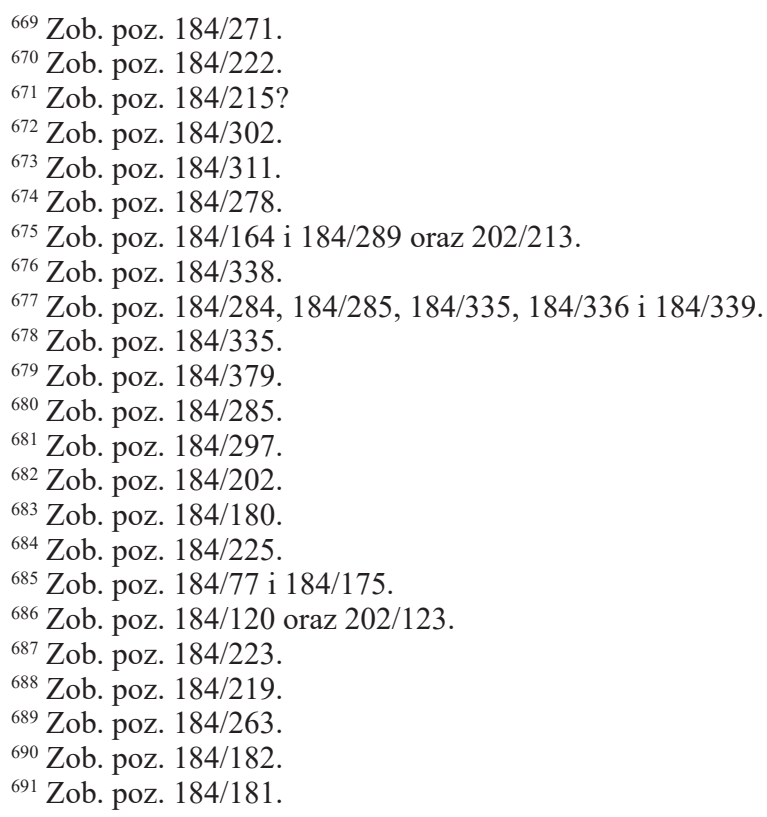


286 Confessio et expositio fidei christianae ${ }^{692}$

287 Be.[rnardi] Gordoni de morbis ${ }^{693}$

288 Magirica

289 Rondelecii methodus cognoscendorum et curandorum morborum ${ }^{694}$

290 Lemnii de occultis naturae miraculis ${ }^{695}$

291 Dicta Flebotomia

292 Leonardi de stripium historia

293 Diono de llagarne Italice

294 Liber de peste Laurentii Spangl. ${ }^{696}$

295 Dialecti Rodolphi 697

296 De verbis anomalis ${ }^{698}$

297 Ioannis Langi carminum liricorum ${ }^{699}$

298 Hesiodi opera ${ }^{700}$

299 Emanuel $^{701}$

300 Psalterium

301 Iacobi Sÿlvii ${ }^{702}$

302 Epigrammata graeca ${ }^{703}$

303 Georgii agricolae de peste ${ }^{704}$

304 Polidorus de prodigiiis ${ }^{705}$

305 Aristotelis organum $^{706}$

306 Claudii Galeni de inaequali intemperie ${ }^{707}$

307 Disputatio Theologica ${ }^{708}$

308 Catullus

309 Svetonii Tranquillii ${ }^{709}$

310 De medicinae scientia activa ${ }^{710}$

311 Hÿpocrates de morbis vulgaribus ${ }^{711}$

312 Linacer $^{712}$

\footnotetext{
${ }^{692}$ Zob. poz. 184/112.

${ }^{693}$ Zob. poz. 184/353?

${ }^{694}$ Zob. poz. $184 / 375$.

${ }^{695}$ Zob. poz. $184 / 337$.

${ }^{696}$ Zob. poz. $184 / 179$.

${ }^{697}$ Zob. poz. 184/244.

${ }^{698}$ Zob. poz. 184/249.

${ }^{699}$ Zob. poz. 184/209.

${ }^{700}$ Zob. poz. 184/191.

${ }^{701}$ Zob. poz. 184/247.

702 Zob. poz. $184 / 248$.

${ }^{703}$ Zob. poz. 184/245.

704 Zob. poz. 184/250.

705 Zob. poz. 184/268.

${ }^{706}$ Zob. poz. 184/231.

707 Zob. poz. 184/246.

${ }^{708}$ Zob. poz. 184/258.

${ }^{709}$ Zob. poz. 184/254.

710 Zob. poz. $184 / 377$.

711 Zob. poz. 184/304.

${ }^{712}$ Zob. poz. 184/216.
} 


\section{Comediae Plauti ${ }^{713}$}

314 De statu religionis et Reip.[ublicae] in regno Galliae

315 De medendis Corporis malis ars medica ${ }^{714}$

316 Oribasii Sardiani medicinalium ${ }^{715}$

317 Comentaria Ioanis Calvini ${ }^{716}$

318 Cathechismus graece

319 Diogenis Laertii de vitis ${ }^{717}$

320 Aphtonii proginasmata ${ }^{718}$

321 De origine et causa pestis patavinae ${ }^{719}$

322 Praeparatio ad mortem ${ }^{720}$

323 Thesaurus Enom: paraphrasis in Rasium

324 Petri Baÿri Ench[i]ridion de meden[dis] malis ${ }^{721}$

325 Philotei in Aphorismos Hÿpocratis ${ }^{722}$

326 Aristotelis Aethica

327 Com[m]entarius in ep[isto]las ad Atticum

328 Arianus

329 Hÿppolitus Brilus ${ }^{723}$

330 Lactantius $^{724}$

331 Ludovici vivi de anima et vita ${ }^{725}$

332 Antonius Musa medicus ${ }^{726}$

333 Epithome Iuris shfeudo[rum $]^{727}$

334 Frumentorum historia ${ }^{728}$

335 Leonelli practica medicinallis ${ }^{729}$

336 Ciceronianum lexicon graeco latinum

337 Epithomae Erasmi in Laurentium Valla ${ }^{730}$

338 Polidorus Vergilius ${ }^{731}$

\footnotetext{
${ }^{713}$ Zob. poz. 184/186.

${ }^{714}$ Zob. poz. $184 / 378$.

${ }^{715}$ Zob. poz. $184 / 295$.

${ }^{716}$ Zob. poz. $184 / 83$.

${ }^{717}$ Zob. poz. $184 / 376$.

${ }^{718}$ Zob. poz. $184 / 259$.

${ }^{719}$ Zob. poz. 184/323.

${ }^{720}$ Zob. poz. $184 / 345$.

${ }^{721}$ Zob. poz. 184/314.

${ }^{722}$ Zob. poz. $184 / 298$.

${ }^{723}$ Zob. poz. $184 / 303$.

${ }^{724}$ Zob. poz. $184 / 178$.

${ }^{725}$ Zob. poz. $184 / 274$.

${ }^{726}$ Zob. poz. $184 / 4$ ?
}

727 Jean Blanc (Johannes Blanchus Marsiliensis, Giovanni Bianchi) (? - ok. 1269), prawnik. Ioan. Blanchi... epitome iuris feudorum iam recens..., Coloniae 1564 lub wydanie z 1565 r. (także kolońskie).

${ }^{728}$ Zob. poz. 184/286.

${ }^{729}$ Zob. poz. 184/272.

${ }^{730}$ Zob. poz. 184/234.

${ }^{731}$ Zob. poz. 184/269. 
339 Aratus Capadox ${ }^{732}$

340 Varrus Flaccus de verborum s[ignifi]catione

341 De Pÿligamia et divortiis tractatus ${ }^{733}$

342 Epitome Galleni in Hÿpocratem ${ }^{734}$

343 Iustinus ${ }^{735}$

344 Theophrastus graece ${ }^{736}$

345 Guilhelmus in Pandectas ${ }^{737}$

346 Erasmi de copia librorum ${ }^{738}$

347 Dialogi Italice

348 Processus iuris Io[ann] is Andreae Samotulani ${ }^{739}$

349 Alexander rascie de Pestilentia ${ }^{740}$

350 Aeschini et Demostenis oratio ${ }^{741}$

351 Ioannis Chrisostomi oratio

352 Ioachimi Hopperi pÿthanon

353 Adrianus Hornanus

354 Io[ann]is Calvini de vitan[dis] Superstitionibus ${ }^{742}$

355 Diosarsi liber Italicus

356 Tusculanae questiones Cicer[onis $]^{743}$

357 Altinous de doctrina Platonis ${ }^{744}$

358 Epithomae Xenodochii ${ }^{745}$

359 Anthonii Cuchÿ Institutiones Iur[is] Canonici

360 Joannes Baptista Egnatius ${ }^{746}$

In sedecimo

361 Makaronka $^{747}$

${ }^{732}$ Zob. poz. 184/142.

${ }^{733}$ Zob. poz. 184/313.

${ }^{734}$ Zob. poz. $184 / 221$.

${ }^{735}$ Zob. poz. $184 / 235$.

${ }^{736}$ Zob. poz. $184 / 341$.

${ }^{737}$ Guillaume Bude. Wiele wydań, przykładowo: Gulielmi Budaei, Parisiensis..., Annotationes in Pandectas tam priores quam posteriores..., Basileae 1557.

${ }^{738}$ Zob. poz. 184/226.

${ }^{739}$ Grzegorz z Szamotuł (Grzegorz Szamotulski, Grzegorz Snopek z Szamotuł) (ok. 1480-1541), profesor prawa, rektor Uniwersytetu Krakowskiego. Wiele wydań, przykładowo: Processus Juris breuior Joannis Andr. per Gregorium Shamotulanū Juris pontificii doctorē pro tyrunculis resolutus cum practica exemplari in Regno Polonię circa strepitum fori spiritualis obseruari solita, [Kraków 1524].

${ }^{740}$ Zob. poz. $184 / 63$.

${ }^{741}$ Zob. poz. $184 / 212$.

${ }^{742}$ Zob. poz. 184/119.

${ }^{743}$ Cicero. Wiele wydań, przykładowo Tusculanarum quaestionum Ciceronis ad M. Brutum libri $5 \ldots$, Venetiis 1569 .

${ }^{744}$ Alcinous (Albinus, Albinous Platonicus, Albinous Smyrnaeus) (II w.), grecki filozof. Wiele wydań, przykładowo: Alcinoi Philosophi Platonici De Doctrina Platonis Liber Graece Et Latine..., Parisiis 1550.

${ }^{745}$ Zob. poz. $184 / 349$.

${ }^{746}$ Zob. poz. $184 / 261$.

${ }^{747}$ Zob. poz. 184/361. 
362 Terentius $^{748}$

363 Fusius de compositione medicamentor[um] $]^{749}$

364 Bocatius Italice $^{750}$

365 Gallenus de locis affectis ${ }^{751}$

366 Vesalii institutiones

367 Pindarus graecus ${ }^{752}$

368 Fracastorius $^{753}$

369 Apianus $^{754}$

370 Trimerus de temperamentis ${ }^{755}$

371 Psalmi Buchanati ${ }^{756}$

372 Adagia Erasmi ${ }^{757}$

373 Lingua Erasmi ${ }^{758}$

374 Erodianus ${ }^{759}$

375 Magia naturalis portae ${ }^{760}$

376 Sinesius de somniis $^{761}$

377 Anatomicae institutiones ${ }^{762}$

378 Ephemerides gemmae

Niewiązane xięgi

379 Alanterius de terrestribus substruen[...

380 vierii observationes ${ }^{763}$

381 Picolominei in mechanicas questiones ${ }^{764}$

382 Iuris methodus

383 Iuris consultus Holomani

384 Anthinomia Juris

385 Thadeus de vene sectione ${ }^{765}$

386 Valentini Scopeci de historia Iuris

\footnotetext{
${ }^{748}$ Prawdopodobnie rzymski komiediopisarz Publius Terentius Afer (Terentius Afrus, Publio Terentio Carthaginese) (ok. 195-159 p.n.e.). Dzieła nie udało się zidentyfikować.

${ }^{749}$ Zob. poz. 184/359.

${ }^{750}$ Zob. poz. $184 / 130$ oraz $202 / 140$ i 202/393

${ }^{751}$ Zob. poz. 184/367.

${ }^{752}$ Zob. poz. $184 / 118$.

${ }^{753}$ Zob. poz. $184 / 370$.

${ }^{754}$ Zob. poz. $184 / 358$.

${ }^{755}$ Zob. poz. $184 / 371$.

${ }^{756}$ Zob. poz. 184/357.

${ }^{757}$ Zob. poz. 184/9 i 184/365 oraz 202/84.

${ }^{758}$ Erasmus Rotterdamus. Wiele wydań, przykładowo: Lingua per Des. Erasmum Roterodamum, diligenter ab authore recognita, Parisiis 1529.

${ }^{759}$ Zob. poz. 184/362.

${ }^{760}$ Zob. poz. $184 / 360$.

${ }^{761}$ Zob. poz. 184/363.

${ }^{762}$ Zob. poz. $184 / 368$.

${ }^{763}$ Zob. poz. 184/144.

${ }^{764}$ Alessandro Piccolomini (Alexander Piccolomineus) (1508-1578), włoski pisarz, filozof, astronom, arcybiskup Sieny. Alexandri Piccolominei In mechanicas quaestiones Aristotelis, paraphrasis paulo quidem plenior..., Venetijs 1565 lub rzymskie wydanie z $1547 \mathrm{r}$.

${ }^{765}$ Zob. poz. 184/342.
} 
387 Cinatius de excusationibus ${ }^{766}$

388 Tabulae Simplicium medicamentorum ${ }^{767}$

389 Theophrasti orationes

390 Carmina Poetarum novem ${ }^{768}$

391 Orationes Theophrasti graece

392 Stanliari opusculum

393 Bocatii Labirintus amoris ${ }^{769}$

394 Economia Pandectarum

\section{BIBLIOGRAFIA}

\section{Źródła rękopiśmienne}

Archiwum Narodowe w Krakowie

Akta miasta Krakowa, rkps 184, 202 (Adv. Crac.).

\section{Źródła drukowane}

Kot Stanisław: Korespondencja Szymona Mariciusza z Pilzna z lat 1551-1555. „Archiwum do Dziejów Literatury i Oświaty" 1929, t. 16, z. 2.

Lachs Jan: Krakowskie księgozbiory lekarskie z XVI-go wieku. „Archiwum dla Historyi Literatury w Polsce" 1913, t. 13, s. 328-412.

Lachs Jan: Kronika lekarzy krakowskich do końca XVI wieku: przyczynki archiwalne. „Archiwum do Dziejów Literatury i Oświaty Polsce” 1910, t. 12, s. 89-176.

Paprocki Bartosz: Herby rycerstwa polskiego, t. 1-3. Wyd. Kazimierz Józef Turowski. Kraków 1858.

Węgierski Wojciech: Kronika Zboru Ewangelickiego Krakowskiego. Oprac. Mariusz Pawelec. Kraków: Parafia Ewangelicka, 2007.

Windakiewicz Stanisław: Materyaty do historii Polaków w Padwie. Protokoły zgromadzeń nacji polskiej w Padwie. Statuta. „Archiwum do Dziejów Literatury i Oświaty w Polsce" 1901, t. 7.

\section{Opracowania}

Album armorum nobilium Regni Poloniae XV-XVIII saec.: herby nobilitacji i indygenatów $X V$-XVIII w. Wstęp, oprac. i edycja Barbara Trelińska. Lublin: Wydawnictwo Uniwersytetu Marii Curie-Skłodowskiej, 2001.

Baczkowska Wanda: Sierpiński (Sierpowski, z Lublina, Lubelczyk) Walenty. W: PSB, t. 37. Warszawa: Instytut Historii Polskiej Akademii Nauk, 1996-1997, s. 359-360.

\footnotetext{
${ }^{766}$ Identyfikacja niepewna. Być może autorem dzieła jest Jacques Cujas (Iacobus Cuiacius, Jacobus Cujacus) (1522-1590), francuski prawnik, humanista. Iacobi Cuiacii... ad titulum digestorum de excusationibus commentarius observationum lib. VI. VII. VIII, Lugduni 1564.

${ }^{767}$ Zob. poz. $184 / 100$ i 184/100a.

${ }^{768}$ Zob. poz. $184 / 343$.

${ }^{769}$ Zob. poz. $184 / 130$ oraz 202/140 i 202/364.
} 
Barycz Henryk: Dudith (w polskim brzmieniu Dudicz) Sbardellat Andrzej. W: PSB, t. 5. Kraków: Polska Akademia Umiejętności, 1939-1946, s. 445.

Barycz Henryk: Ephorinus Anzelm. W: PSB, t. 4. Kraków: Polska Akademia Umiejętności, 1938, s. 281-282.

Barycz Henryk: Grzepski Stanisław. W: PSB, t. 9. Wrocław: Zakład Narodowy im. Ossolińskich Wydawnictwo Polskiej Akademii Nauk, 1961, s. 99-102.

Barycz Henryk: Historia Uniwersytetu Jagiellońskiego w epoce humanizmu. Kraków: Uniwersytet Jagielloński, 1935.

Barycz Henryk: Kromer Marcin. W: PSB, t. 15. Wrocław: Zakład Narodowy im. Ossolińskich Wydawnictwo Polskiej Akademii Nauk, 1970, s. 319-325.

Barycz Henryk: Maricjusz (Marycjusz) Szymon. W: PSB, t. 20. Wrocław: Zakład Narodowy im. Ossolińskich Wydawnictwo Polskiej Akademii Nauk, 1975, s. 12-14.

Barycz Henryk: Pięćdziesiąt lat „Polskiego Stownika Biograficznego”: jego narodziny trudne poczatki - perspektywy rozwoju. „Biuletyn Biblioteki Jagiellońskiej” 1988, R. 38, s. 185-226.

Barycz Henryk: Rozwój nauki polskiej w dobie odrodzenia. W: Odrodzenie w Polsce. Historia nauki, cz. 1. Red. Bogdan Suchodolski. Warszawa: Państwowy Instytut Wydawniczy, 1956.

Barycz Henryk: Rożanka (Rosarius) Stanisław. W: PSB, t. 32. Wrocław: Zakład Narodowy im. Ossolińskich Wydawnictwo Polskiej Akademii Nauk, 1989-1991, s. 431-433.

Barycz Henryk: Rożanka (Rosatus) Stanisław. W: PSB, t. 32. Wrocław: Zakład Narodowy im. Ossolińskich Wydawnictwo Polskiej Akademii Nauk, 1989-1991, s. 433-434.

Barycz Henryk: Rożanka Walenty. W: PSB, t. 32. Wrocław: Zakład Narodowy im. Ossolińskich Wydawnictwo Polskiej Akademii Nauk, 1989-1991, s. 434.

Barycz Henryk: Saga kleparskiej rodziny Różanków. Historia trochę kryminalna. W: Idem: Z epoki renesansu, reformacji i baroku: prady-idee - ludzie - ksiażki. Warszawa: Państwowy Instytut Wydawniczy, 1971, s. 400-452.

Barycz Henryk: Spojrzenia w przeszłość polsko-włoska. Wrocław: Zakład Narodowy im. Ossolińskich, 1965.

Barycz Henryk: W blaskach epoki odrodzenia. Warszawa: Państwowy Instytut Wydawniczy, 1968.

Barycz Henryk: Z epoki renesansu, reformacji i baroku: prądy - idee - ludzie - książi. Warszawa: Państwowy Instytut Wydawniczy, 1971.

Barycz Henryk: Z zaścianka na Parnas. Drogi kulturowego rozwoju Jana Kochanowskiego i jego rodu. Kraków: Wydawnictwo Literackie, 1981.

Biedrzycka Agnieszka, Pietrzyk Zdzisław: Śmieszkowic (Gelasinus) Mikołaj. W: PSB, t. 51. Warszawa: Instytut Historii Polskiej Akademii Nauk, 2016-2017, s. 83-85.

Bieniarzówna Janina, Małecki Jan M.: Dzieje Krakowa. T. 2: Kraków w wiekach XVIXVIII. Kraków: Wydawnictwo Literackie, 1984.

Bodniak Stanisław: Bużeński Hieronim. W: PSB, t. 3. Kraków: Polska Akademia Umiejętności, 1937, s. 156-157.

Brückner Aleksander: Dzieje kultury polskiej, t. 2. Warszawa: Książka i Wiedza, 1958.

Budka Włodzimierz: Biblioteka Decjuszów. „Silva Rerum” 1928, t. 4, s. 110-126. 
Budka Włodzimierz: Biblioteka Mikołaja Bronowskiego. „Przegląd Biblioteczny” 1930, R. 4, s. 209-215.

Chmiel Adam: Domy krakowskie. Ulica Floryańska, cz. 2. Kraków: Towarzystwo. Miłośników Historii i Zabytków Krakowa, 1920.

Chmiel Adam: Domy krakowskie. Ulica św. Jana. Cz. 2: Liczby or. parzyste (2-32). Kraków: Towarzystwo Miłośników Historii i Zabytków Krakowa, 1924.

Cracovia litterarum: kultura umysłowa i literacka Krakowa i Małopolski w dobie Renesansu: księga zbiorowa Międzynarodowej Sesji Naukowej w czterechsetlecie zgonu Jana Kochanowskiego (w Krakowie, 10-13 października 1984 r.). Red. Tadeusz Ulewicz. Wrocław: Zakład Narodowy im. Ossolińskich Wydawnictwo Polskiej Akademii Nauk, 1991.

Dawna facecja polska. Oprac. Julian Krzyżanowski, Kazimiera Żukowska-Bilip. Warszawa: Państwowy Instytut Wydawniczy, 1960.

Dworzaczek Włodzimierz: Hetman Jan Tarnowski: z dziejów możnowładztwa małopolskiego. Warszawa: Instytut Wydawniczy PAX, 1985.

Grabowski Ambroży: Starożytności historyczne polskie, czyli Pisma i pamiętniki do dziejów dawnej Polski, listy królów i znakomitych mężów, przypowieści, przysłowia i t.p., t. 1. Kraków: Nakład i druk Józefa Czecha, 1840.

Grzebień Ludwik: Biblioteka biskupa Hieronima Rozrażewskiego (1542-1600). „Archiwa, Biblioteki i Muzea Kościelne" 1971, t. 22, s. 61-168.

Hajdukiewicz Leszek: Biblioteka Stanisława Grzepskiego. „Przegląd Geodezyjny” 1967, R. 39, nr 5, dod., s. 16-23.

Hajdukiewicz Leszek: Księgozbiór i zainteresowania bibliofilskie Piotra Tomickiego na tle jego działalności kulturalnej. Wrocław: Zakład Narodowy im. Ossolińskich, 1961.

Hajdukiewicz Leszek, Wiśniewski Jerzy: Maciej z Krajny h. Topór. W: PSB, t. 19. Wrocław: Zakład Narodowy im. Ossolińskich Wydawnictwo Polskiej Akademii Nauk, 1974, s. 21-22.

Hajdukiewicz Leszek: Maciej z Miechowa. W: PSB, t. 19. Wrocław: Zakład Narodowy im. Ossolińskich Wydawnictwo Polskiej Akademii Nauk, 1974, s. 28-33.

Hajdukiewicz Leszek: Nidecki Patrycy Andrzej. W: PSB, t. 22. Wrocław: Zakład Narodowy im. Ossolińskich Wydawnictwo Polskiej Akademii Nauk, 1977, s. 713-717.

Hajdukiewicz Leszek: Schneeberger (Schneberger) Anton. W: PSB, t. 35. Warszawa: Instytut Historii Polskiej Akademii Nauk, 1994, s. 568-571.

Historia nauki polskiej, t. 1. Red. Bogdan Suchodolski. Wrocław: Zakład Narodowy im. Ossolińskich Wydawnictwo Polskiej Akademii Nauk, 1970.

Historia nauki polskiej, t. 6. Red. Bogdan Suchodolski. Dokumentacja bio-bibliograficzna. Indeks biograficzny tomu 1 i 2. Oprac. Leszek Hajdukiewicz. Wrocław: Zakład Narodowy im. Ossolińskich Wydawnictwo Polskiej Akademii Nauk, 1974.

Jaglarz Monika: Ksieggarstwo krakowskie XVI wieku. Kraków: Towarzystwo Miłośników Historii i Zabytków Krakowa, 2004.

Janowi Kochanowskiemu - ziemia rodzinna: księga referatów radomsko-kielecko-czarnoleskiej sesji naukowej 450-lecia urodzin poety $w$ dniach 29-31 maja 1980 r. Red. Jan Pacławski, Tadeusz Ulewicz. „Rocznik Świętokrzyski” 1981, t. 9. 
Jaroszyńska Maria: Biblioteka Jana Góry rajcy krakowskiego z XVI w. „Roczniki Biblioteczne" 1962, R. 6, z. 3/4, s. 1-28.

Koranyi Karol, Patkaniowski Michał: Groicki (Grodzicki) Bartłomiej. W: PSB, t. 8. Wrocław, Zakład Narodowy im. Ossolińskich, Wydawnictwo Polskiej Akademii Nauk, 1959-1960, s. 628-629.

Kot Stanisław: Polska złotego wieku a Europa. Studia i szkice. Warszawa: Państwowy Instytut Wydawniczy, 1987.

Kowalska Halina: Reformacja w Krakowie w czasach Jana Kochanowskiego. W: Cracovia litterarum: kultura umysłowa i literacka Krakowa i Małopolski w dobie Renesansu: księga zbiorowa Międzynarodowej Sesji Naukowej w czterechsetlecie zgonu Jana Kochanowskiego (w Krakowie, 10-13 października 1984 r.). Red. Tadeusz Ulewicz. Wrocław: Zakład Narodowy im. Ossolińskich Wydawnictwo Polskiej Akademii Nauk, 1991, s. 247-266.

Kowalska Halina: Z dziejów reformacji w Krakowie. W: Szkice z dziejów Krakowa od czasów najdawniejszych do pierwszej wojny światowej. Red. Janina Bieniarzówna. Kraków: Wydawnictwo Literackie, 1968, s. 181-212.

Kraków stary i nowy: dzieje kultury. Red. Janina Bieniarzówna. Kraków: Państwowy Instytut Wydawniczy, 1968.

Kurdybacha Łukasz: Fogelweder Stanisław. W: PSB, t. 7. Kraków: Polska Akademia Umiejętności - Polska Akdemia Nauk Wydawnictwo Zakładu Narodowego im. Ossolińskich, 1948-1958, s. 44-46.

Kurdybacha Łukasz: Pisma wybrane, t. 3. Warszawa: Wydawnictwa Szkolne i Pedagogiczne, 1976.

Kurdybacha Łukasz: Stanisław Fogelweder - humanista i dyplomata polski XVI w. W: Idem, Pisma wybrane, t. 3. Warszawa: Wydawnictwa Szkolne i Pedagogiczne, 1976, s. 7-31.

Lachs Jan: Ephorinus i Rożanka: z dziejów uczestnictwa lekarzy w ruchu reformacyjnym. „Reformacja w Polsce” 1922, R. 2, s. 185-197.

Lachs Jan: Polscy uczniowie Padewskiej Szkoły Lekarskiej. Nadbitka z „Archiwum Historii i Filozofii Medycyny oraz Historii Nauk Przyrodniczych” 1925.

Lepszy Kazimierz: Chroberski Daniel. W: PSB, t. 3. Kraków: Polska Akademia Umiejętności, 1937, s. 446.

Lewicka-Kamińska Anna: Biblioteka Jagiellońska w latach 1492-1655. W: Jerzy Zathey, Anna Lewicka-Kamińska, Leszek Hajdukiewicz: Historia Biblioteki Jagiellońskiej. T. 1: 1364-1775. Red. Ignacy Zarębski. Kraków: Państwowe Wydawnictwo Naukowe, 1966, s. 131-271.

Lewicka-Kamińska Anna: Renesansowy księgozbiór Mikołaja Czepla w Bibliotece Jagiellońskiej. Wrocław: Zakład Narodowy im. Ossolińskich Wydawnictwo Polskiej Akademii Nauk, 1956.

Łempicki Stanisław: Renesans i humanizm w Polsce. Materiały do studiów. Warszawa: Spółdzielnia Wydawniczo-Oświatowa Czytelnik, 1952.

Maleczyńska Kazimiera: Z dziejów księgozbiorów mieszczańskich w Polsce 1506-1572. Wrocław: Wydawnictwo Uniwersytetu Wrocławskiego, 1991.

Noga Zdzisław: Krakowska rada miejska w XVI wieku: studium o elicie władzy. Kraków: Wydawnictwo Naukowe Akademii Pedagogicznej, 2003. 
Noga Zdzisław: Urzędnicy miejscy Krakowa. Cz. 2: 1500-1794. Kraków: Wydawnictwo Naukowe Akademii Pedagogicznej, 2008.

Obrońcy języka polskiego: wiek XV-XVIII. Oprac. Witold Taszycki. Wrocław: Zakład Narodowy im. Ossolińskich, 1953.

Odrodzenie w Polsce. Historia nauki, cz. 1. Red. Bogdan Suchodolski. Warszawa: Państwowy Instytut Wydawniczy, 1956.

Pieradzka Krystyna: Aichler Stanisław. W: PSB, t. 1. Kraków: Polska Akademia Umiejętności, 1935, s. 33-34.

Poczet soltysów, wójtów, burmistrzów i prezydentów miasta Krakowa: (1228-2010). Red. Bogdan Kasprzyk. Kraków: Urząd Miasta Krakowa, 2010.

Ptaśnik Jan: Bonerowie. „Rocznik Krakowski” 1905, R. 7, s. 1-134.

Quirini-Popławska Danuta: Środowisko naukowe Uniwersytetu Padewskiego w okresie studiów Klemensa Janickiego. ,Symbolae Philologorum Posnaniensium Graecae et Latinae" 2017, t. 27, z. 2, s. 55-74.

Quirini-Popławska Danuta: Z Prus do Italii. Profesor Uniwersytetu Padewskiego Melchiorre Guilandini i jego podróże. „Portolana. Studia Mediterranea” 2009, vol. 4, s. 139-159.

Rybicki Paweł: Odrodzenie. W: Historia nauki polskiej, t. 1. Red. Bogdan Suchodolski. Wrocław: Zakład Narodowy im. Ossolińskich Wydawnictwo Polskiej Akademii Nauk, 1970, s. 195-436.

Sołtan Andrzej: Roguski (Rogucki) Sylwester. W: PSB, t. 31. Wrocław: Zakład Narodowy im. Ossolińskich Wydawnictwo Polskiej Akademii Nauk, 1988-1989, s. 487-488.

Szelińska Wacława: Książka Erazma z Rotterdamu w środowisku krakowskim w XVI wieku. Kraków: Wydawnictwo Naukowe WSP, 1990.

Szkice z dziejów Krakowa od czasów najdawniejszych do pierwszej wojny światowej. Red. Janina Bieniarzówna. Kraków: Wydawnictwo Literackie, 1968.

Ślaski Jan: Marian Leżeński - padewczyk zapomniany. „Odrodzenie i Reformacja w Polsce" 2004, t. 47, s. 65-93.

Urban Wacław: Heretycy parafii Mariackiej w Krakowie 1568. „Odrodzenie i Reformacja w Polsce"1987, t. 32, s. 167-177.

Volsciana: katalog renesansowego księgozbioru Piotra Dunin-Wolskiego, biskupa płockiego. Oprac. Andrzej Obrębski. Kraków: Księgarnia Akademicka, Warszawa: Instytut Cervantesa, 1999.

Wawel-Louis Józef: Przechadzka kronikarza po Rynku Krakowskim. Kraków: Druk. „Czasu", 1890.

Wierzbowski Teodor: Bibliographia Polonica XV ac XVI ss: Vol. 2: continens numeros 801-2000, Varsovia: C. Kowalewski, 1891.

Wojciechowska Maria: Z dziejów książki w Poznaniu w XVI wieku. Poznań: Fiszer i Majewski Księgarnia Uniwersytecka, 1927.

Wróblewski Romuald: Podróże jako źródło wiedzy o Ameryce. „Odrodzenie i Reformacja w Polsce", 1972, t. 17, s. 63-86.

Zathey Jerzy, Lewicka-Kamińska Anna, Hajdukiewicz Leszek: Historia Biblioteki Jagiellońskiej. T. 1: 1364-1775. Red. Ignacy Zarębskiego. Kraków: Państwowe Wydawnictwo Naukowe, 1966. 


\section{PODSUMOWANIE \\ Renesansowy księgozbiór krakowskiego lekarza Stanisława Różanki}

Artykuł poświęcony jest bibliotece krakowskiego medyka Stanisława Różanki (ok. 1520-1572). Doktor filozofii i medycyny padewskiej promocji, obracający się wśród znakomitych osobowości polskiego renesansu, należał do uznanych lekarzy swego czasu. Był ważną postacią kalwińskiego zboru w Krakowie. Będąc zamożnym człowiekiem, część dochodów przeznaczał na gromadzoną całe życie bibliotekę. Jego księgozbiór liczył blisko 400 dzieł, co stawia Różankę w gronie właścicieli największych bibliotek tego okresu, nie tylko w stolicy Królestwa Polskiego. Imponująca jej zawartość pokazuje szerokie, humanistyczne zainteresowania właściciela. Najważniejszą częścią artykułu są dwa inwentarze księgozbioru Różanki sporządzone w latach 1572 i 1583 . Wydanie obecne pokazuje wszystkie zawarte w obu rękopisach pozycje, dzięki czemu w pełni ukazana jest wyjątkowość księgozbioru Stanisława Różanki. Jest też podstawą do dalszych szczegółowych badań dotyczących renesansowych księgozbiorów krakowskich mieszczan.

\section{SUMMARY \\ Renaissance book collection of Stanislaus Rosarius}

The subject of the paper is the library of Stanislaus Rosarius (1520-1572). This doctor of philosophy and medicine, a graduate of the University of Padua who socialized with a number of key figures of the Polish Renaissance, was a highly regarded physician and an eminent member of the Calvinist congregation in Krakow. Being a prosperous practitioner, during his entire career he allocated part of his income to purchasing books for his private library. In total, Rosarius amassed almost 400 volumes, which made his library one of the largest of its kind at that time, not just within the royal capital of Poland. The library's impressive range distinctly shows the broadness of the humanistic interests of its owner. As its main part, the article comprises two inventories of Rosarius' books, one compiled in 1572 and the other in 1583. The present publication lists all entries from both the manuscripts, amply demonstrating the unique character of the collection as well as providing a sound basis for further detailed studies on Renaissance book collections in the possession of Krakow burghers.

SŁOWA KLUCZOWE: Stanisław Różanka, krakowscy lekarze, krakowscy mieszczanie, renesansowe księgozbiory, kultura książki

KEY WORDS: Stanislaus Rosarius, Krakow physicians, Krakow burghers, Renaissance book collections, book culture 